Danilo Fernandes Costa

\title{
Prevenção da exposição ao benzeno no Brasil
}

Tese apresentada à Faculdade de Medicina da Universidade de São Paulo para obtenção do título de Doutor em Ciências

Área de concentração: Patologia Orientador: Prof. Dr. Eduardo Massad 


\section{Dados Internacionais de Catalogação na Publicação (CIP)}

Preparada pela Biblioteca da

Faculdade de Medicina da Universidade de São Paulo

Creprodução autorizada pelo autor

\section{Costa, Danilo Fernandes}

Prevenção da exposição ao benzeno no Brasil / Danilo Fernandes Costa. -- São Paulo, 2009.

Tese(doutorado)--Faculdade de Medicina da Universidade de São Paulo. Departamento de Patologia.

Área de concentração: Patologia.

Orientador: Eduardo Massad.

Descritores: 1.Benzeno/toxicidade 2.Saúde do trabalhador 3.Vigilância em saúde do trabalhador 4.Medicina do trabalho 5.Toxicologia 6.Câncer ocupacional 


\section{SUMÁRIO}

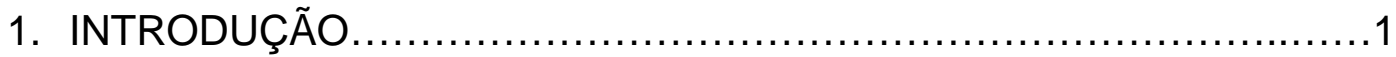

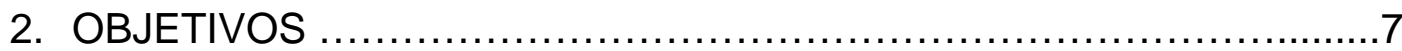

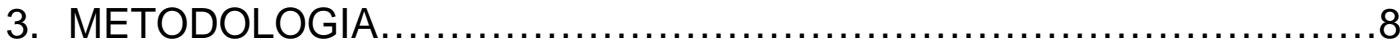

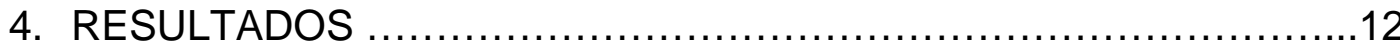

4.1. A experiência internacional..........................................20

4.1.1. Os primeiros achados no século XIX .............................20

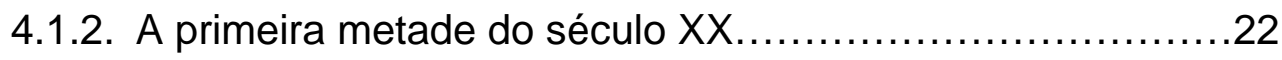

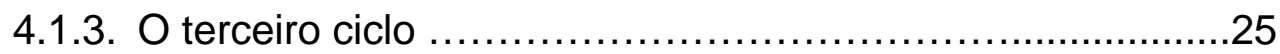

4.1.4. O momentro atual ...........................................

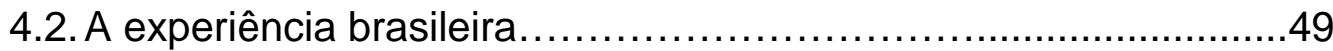

4.2.1. O primeiro período, dos anos 30 a 60 do século XX............49

4.2.2. O segundo período, de 1960 até 1982: aumento da .produção, difusão do uso e aparecimento dos casos de

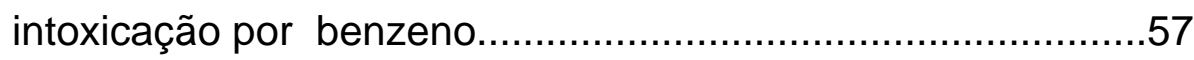

4.2.3. O terceiro período, de 1982 a 1995: o descontrole da exposição ocupacional ao benzeno no centro da cadeia produtiva.......

4.2.4. Novos parâmetros para a prevenção da exposição ao benzeno: o acordo e a legislação do benzeno de 1995........130

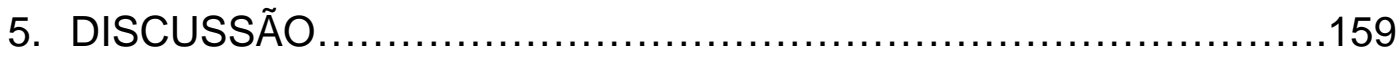

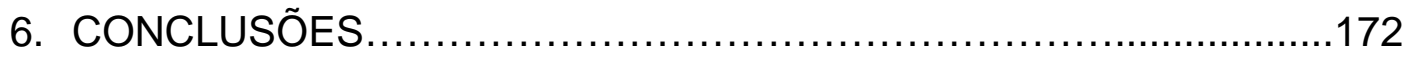

7. REFERÊNCIAS BIBLIOGRÁFICAS.......................................174 
Costa DF. Prevenção da exposição a benzeno no Brasil [tese]. São Paulo: Faculdade de Medicina, Universidade de São Paulo; 2009. 179 p.

A prevenção da exposição ao benzeno têm sido uma preocupação em diversos países desde o final do século XIX. Neste estudo foi feita uma recuperação do percurso histórico da utilização industrial do benzeno no Brasil, da produção técnico-científica sobre a saúde dos trabalhadores a ele expostos e dos conflitos sociais que tiveram maior repercussão, identificando com isto os elementos presentes nestes processos capazes de dar resposta à indagação central da investigação: se as restrições legais à exposição ao benzeno influenciaram positivamente na prevenção da exposição a esta substância no país. A experiência internacional serviu como contraponto, pois muitas situações que ocorreram nos países centrais se repetiram posteriormente nos países de industrialização tardia. Os resultados mostraram que, no Brasil e no mundo, pode-se dividir em quatro períodos a exposição a benzeno. Um período inicial, com pouco uso e quase sem notícias de casos. Um segundo momento em que a utilização aumenta de forma significativa e as exposições se tornam importantes: na experiência internacional este é um momento de ocorrência de muitos casos de Aplasia de Medula; no Brasil, apesar das exposições também altas, não ocorrem praticamente diagnósticos. Um terceiro período em que há uma mudança de perfil de exposição com a proibição da presença de benzeno em solventes e a diminuição das concentrações ambientais, mas que permanecem ainda a níveis relativamente elevados, e uma mudança do padrão de morbi-mortalidade com uma maior valorização das leucemias. No quarto período as exposições ocupacionais diminuem ainda mais, e as exposições ambientais aos Compostos Orgânicos Voláteis, grupo em que o benzeno está incluído, se tornam uma discussão marcante, aproximando definitivamente estas duas questões.

As conclusões apontaram para a ineficiência das restrições legais quando dissociadas do contexto sócio-histórico, como ocorreu nos 50 primeiros anos analisados no Brasil, mas, quando, ao contrário, estiveram inseridas na dinâmica social do país, tiveram impacto muito positivo, como ocorreu no período subsequente. A reconstituição histórica feita mostrou uma riqueza muito grande na regulamentação brasileira da exposição ao benzeno, com um corpo legal com acentuado caráter participativo. Os padrões de exposição diminuíram significativamente com setores melhor preparados conceitualmente para lidar com as políticas de boas práticas. $O$ reconhecimento dos agravos à saúde passou por um período de maior efetividade nos anos 1980, mas teve um recuo na década de 1990 que não foi superado até o presente momento.

As ações realizadas no Brasil consolidaram um modelo de vigilância da saúde bem sucedido baseado principalmente em aspectos qualitativos e de participação com grande dinâmica social. Ao se comparar com a situação internacional parece haver uma excessiva valorização, em outros países, de aspectos quantitativos relacionados à exposição ao benzeno, sendo difícil identificar, em especial nos países centrais, se houve uma retomada dos estudos feitos até a década de 1980 e se os trabalhadores e o serviço público desses países têm informações sobre o que se passa nestas empresas. Apesar dos muitos limites do processo brasileiro parece haver possibilidades significativas de uma evolução positiva.

Descritores: 1.benzeno; 2.saúde do trabalhador; 3.toxicologia; 4.medicina do trabalho; 5.cancer ocupacional; 6.vigilância à saúde 
Costa DF. Prevention against exposure to benzene im Brazil. [thesis]. Faculty of Medicine, University of São Paulo, SP (Brazil), 2009. 179 p.

Prevention against exposure to benzene has been a concern in several countries since the end of the XIXth century. In this work we recover a historical route of the industrial use of benzene in Brazil, of the technical and scientific production on the health of workers exposed to it and the social conflicts that had greater repercussion, in an attempt to retrieve the elements from those processes that enable us to answer the central question of this investigation: whether or not the legal restriction to benzene exposure influenced in the prevention against benzene exposure in this country. The international experience served as a counterpoint, because in several situations of some central countries repeated themselves in countries of later industrialization later on. The result showed that, in Brazil and in the world, benzene exposure could be divided into four periods. One initial period, with little use and almost without reported cases. A second period in which the use of benzene increases significantly and exposure is more important: in the international experience this is a moment in which several cases of bone marrow aplasia are reported; in Brazil, in spite of high levels of exposure, diagnosis are practically absent. A third period in which it is noted a change in the exposure profile with the prohibition of benzene in solvents and a reduction in environmental concentrations, but at levels relatively high and a change in the morbid-mortality pattern with leukemia being very valued. In the fourth period occupational exposure are even more reduced and environmental exposure to Volatile Organic Components, group in which benzene is included, turns to be a marked discussion, approaching definitively these two questions. Conclusion point to the inefficacy of legal restrictions when dissociated from social-historical contexts, as in the first 50 years analyzed in Brazil, but when, in contrast, included in the country's social dynamics had a very positive impact, as occurred in the subsequent period. The historical reconstitution carried out showed richness in the Brazilian regulation of exposure to benzene with a legal body of accentuated participative characteristic. The patterns of exposure reduced significantly with better-prepared sectors to deal with the policy of good practices. The admission of health appeals undergone a period of greater efficacy in the 1980's but retrocede in the 1990's, not surpassed until now.

Actions carried out in Brazil consolidated a model of health surveillance well succeeded basing mainly on qualitative aspects and on the participation of great social dynamics. When compared with the international situation, it seems to be an excessive valuation of quantitative aspects in other countries, related to benzene exposure, and it is difficult to identify, in particular in the central countries, whether there is a retake of studies carried out until the 1980's and whether the workers and the public services of those countries have information on what is happening in those companies. In spite of several limitations in the Brazilian process, it seems to be significant possibilities of a positive evolution.

Descriptors: 1. benzene; 2. occupational health; 3.toxicology; 4. occupational medicine; 5.occupational cancer; 6 .health surveillance 


\section{INTRODUÇÃO}

O mundo contemporâneo tem passado por mudanças rápidas e intensas nas últimas décadas, com grande impacto nas formas de trabalho, na saúde e no ambiente. Vários fenômenos têm ocorrido simultaneamente: um grande aumento do comércio global, da riqueza e da produção industrial; uma ampliação do número de pessoas que trabalham; novas tecnologias de informação e novos processos de produção químicos, biotecnológicos e farmacêuticos que ampliaram as opções de produção de baixo custo, baixo gasto energético e estratégias de reciclagem que geraram novos tipos de trabalho. Para a grande maioria dos trabalhadores dos países menos industrializados, a liberação do comércio veio acompanhada da transferência de tecnologia, produtos químicos, processos e resíduos obsoletos e perigosos, muitos deles não mais utilizados nos seus países de origem, que provocam doenças difíceis de serem reconhecidas (Loewenson, 2001).

Enquanto muitas das condições provocadas por estas situações são reconhecidas como problemas nos países industrializados, elas são muito menos reconhecidas enquanto tal nos países em desenvolvimento, por uma combinação de diversos fatores, entre os quais a cronicidade de muitas dessas doenças, que não são detectadas devido à instabilidade dos empregos; à dificuldade em separar os fatores ocupacionais dos fatores ambientais, principalmente daqueles relacionados com graus importantes de pobreza, em particular os que levam à desagregação social, infelizmente bastante comuns 
nestes países; ao pouco monitoramento e a sistemas regulatórios ineficientes, que implicam que uma parte importante da morbidade ocupacional não é rotineiramente notificada, particularmente as doenças crônicas ligadas a fatores químicos, ergonômicos e psicosociais (Loewenson, 2001).

Neste processo de globalização as substâncias químicas cumprem um papel importante. Utilizadas desde os primórdios da humanidade, sua importância vem crescendo ao longo do tempo constituindo hoje o que pode ser denominado de "questão química". Através desta locução indica-se, neste trabalho, o conjunto dos problemas sociais, econômicos e ambientais que se referem aos diversos setores da economia envolvidos com as substâncias químicas. Dá-se destaque especial aos trabalhadores e aos inúmeros impactos ambientais relacionados com a extração, produção, manejo, utilização, dispersão, decomposição, e tantas outras formas de interação com estas substâncias que têm presença determinante no mundo neste terceiro milênio, e que constituem o pano de fundo da discussão em que o benzeno está inserido.

A produção de substâncias químicas vem aumentando de forma progressiva de uma maneira impressionante no mundo. Em 1930 eram produzidas um milhão de toneladas de produtos químicos. Atualmente são mais de 400 milhões de toneladas, sendo mais de 100 mil as substâncias registradas na União Européia, 30 mil delas comercializadas em quantidades superiores a uma tonelada (Musu, 2006). A industria química é a terceira maior atividade industrial no mundo hoje, empregando 10 milhões de pessoas em todo o mundo e movimentando vendas globais em torno de 1.481 bilhões de Euros em 2002 . 
A maior parte do trabalho desenvolvido pela indústria química ocorre em empresas de pequeno e médio porte, ainda que possam com frequencia envolver capital muito significativo. É também uma das industrias mais diversificadas do mundo, com um espectro muito amplo de substâncias e produtos, que vão de uma grande quantidade de produtos químicos de base como agrotóxicos, aditivos, isolantes, revestimentos, produtos farmacêuticos a uma quantidade quase infinita de produtos especializados(Schorling e Lind, 2004).

Praticamente todos os países têm industria química, mas a parte principal da produção vem de 16 países; a União Européia estava, em 2002, entre os principais produtores com $30 \%$ da produção mundial, sendo, naquele ano, a maior região produtora, com 6 entre 10 das maiores companhias químicas do mundo, segundo o Chemichal Industry Council (Cefic) (Schorling e Lind, 2004).

No processo de globalização está havendo uma redistribuição de tarefas, como parte da reestruturação produtiva, que atinge também a industria química. As industrias dos países centrais estão se tornando ainda mais tecnológicas, cabendo aos países periféricos um aumento na contribuição da produção industrial de matérias primas básicas. O crescimento destas industrias nos países periféricos não significa uma perda de mercado para as empresas dos países centrais, ou um aumento de competição. Ao contrário, são estas mesmas empresas que já estão instaladas ou se instalando nos países periféricos (Musu, 2006). 
Este processo de reestruturação produtiva, em curso no mundo todo, tem na América Latina um aspecto particular relacionado à produção de petróleo e gás que, no presente momento, pode aumentar muito, atendendo às necessidades apontadas acima, com um crescimento substantivo da extração de óleo e gás e o consequente aumento da produção de matéria prima, e uma grande expansão do parque petroquímico no Brasil, Venezuela, Equador, Bolívia e eventualmente outros países do cone sul.

Os riscos da exposição ao benzeno são conhecidos há muito tempo e vêm sendo objeto de tratamentos diversos, nacional e internacionalmente. Os elementos centrais da importância desta substância estão ligados à sua toxicidade e à difusão de sua utilização em razão da facilidade de sua produção a partir do petróleo, do carvão mineral e sua presença no condensado de gás natural. Trata-se de substância hematotóxica e cancerígena, que tem porém vasta utilização na cadeia produtiva de extração e refino de petróleo e na produção de aço, principalmente, mas não apenas, em razão de sua presença nas matérias primas destes processos.

Trata-se, portanto, de uma questão complexa e intricada, pois ao mesmo tempo em que se conhecem cada vez mais as características tóxicas deste produto, sua presença e utilização é parte de processos essenciais no mundo em que vivemos, não havendo a curto, médio e mesmo longo prazo, perspectivas de mudança significativa nestas cadeias produtivas.

O desenvolvimento tecnológico e das matrizes energéticas do século $X X$ tiveram participação fundamental das substâncias químicas, com aumento de 
sua utilização industrial nas mais diversas atividades, constituindo-se hoje em parte indispensável de praticamente todas as atividades humanas, sejam elas industriais, comerciais ou domésticas.

Em especial, e não apenas no que concerne ao benzeno, devem ser consideradas as cadeias produtivas das industrias de petróleo e aço, geradoras e participantes ativas de boa parte dos processos envolvendo as substâncias químicas protagonistas deste momento histórico, que também são resultantes da principal matriz energética mundial: a matéria orgânica fóssil de onde são retirados o petróleo e o carvão mineral. Estes dois elementos são a base para a produção de combustíveis, mas também têm participação em inúmeros processos produtivos relacionados a estas cadeias, em especial as industrias petroquímica, química de segunda geração e siderúrgica.

O benzeno é, portanto, tema de discussão e interesse ocupacional e ambiental em todo o mundo, seja pela sua presença em produtos, por sua utilização industrial ou pelas emissões que o contêm, principalmente as de veículos automotivos. As características de sua toxicidade justificam o destaque que o benzeno tem em relação ao demais hidrocarbonetos aromáticos, grupo do qual faz parte. O benzeno, por ser uma substância reconhecidamente cancerígena e pela grande difusão de sua utilização, tem sido objeto de controle em todo o mundo, em razão de suas características de contaminante universal e de seus potenciais efeitos à saúde.

Um marco fundamental do controle do benzeno no Brasil foi a proibição de sua presença em solventes, em 1982. Quase ao mesmo tempo ocorreu a 
discussão sobre exposição ocupacional a benzeno no setor siderúrgico, que desencadeou uma série de ações sindicais, de vigilância epidemiológica e de direitos previdenciários. Este período foi marcado por uma intensa discussão da reforma sanitária brasileira sob influência da italiana, em que a saúde dos trabalhadores teve papel central (Machado et al., 2003).

Segundo Machado, este período é caracterizado pela construção das bases de intervenção que desembocariam na negociação do acordo quando da caracterização do benzeno como substância cancerígena, que ocorreu em 1994. Com o trabalho desenvolvido posteriormente, com grande articulação social, muitos desafios foram postos. Para o autor, mesmo sob fortes tensões, o acúmulo proveniente da interação fez com que o modelo de vigilância da exposição ao benzeno ficasse cada vez mais complexo e claro, reafirmando a necessidade de uma abordagem múltipla e transversal (Machado et al, 2003).

Este estudo foi realizado na perspectiva de contribuir com os conhecimentos nesta área, pois apesar da riqueza da experiência do benzeno, há relativamente poucas publicações que avaliam seus resultados e que procuram ampliar a visão sobre este processo histórico, que teve repercussões importantes sobre a saúde do trabalhador de forma geral no Brasil. 


\section{OBJETIVOS}

\section{Objetivo Geral}

Analisar a importância da legislação brasileira de restrição à exposição a benzeno na prevenção da exposição dos trabalhadores a esta substância no Brasil.

\section{Objetivos específicos}

1 - Realizar uma reconstituição histórica da regulamentação referente aos riscos ocupacionais no uso industrial do benzeno no Brasil.

2 - Identificar as características da exposição ao benzeno no Brasil e as mudanças ocorridas nos diferentes setores produtivos.

3 - Interpretar as modificações ocorridas no reconhecimento dos agravos à saúde relacionados à exposição ao benzeno no Brasil.

4 - Estabelecer uma comparação entre as principais ações realizadas no Brasil na prevenção da exposição ao benzeno com as desenvolvidas em outros países. 


\section{METODOLOGIA}

Em função do objetivo central deste estudo, definido em discussão com a banca de qualificação a partir da necessidade de definir uma questão norteadora clara e bem delimitada, foi estabelecida uma pergunta condutora: as restrições legais impostas à exposição ao benzeno no Brasil influenciaram eventuais avanços ocorridos na prevenção da exposição a esta substância no país?

Para colher elementos que pudessem ajudar a entender o papel que possa ter tido a legislação na melhora da prevenção à exposição ao benzeno e responder a esta pergunta, foi realizada a coleta dos dados da produção científica existente em jornais e programas de pós-graduação, através de diversas fontes de informação. Na Internet com o sistema OVID, com o qual a USP têm convênio, foram levantados artigos internacionais a partir da busca do tema "benzene and leukemia", que lista centenas de artigos produzidos nos últimos anos. Foram selecionados os artigos referentes às experiências internacionais de maior repercussão. Foi feito também levantamento de documentos, folhetos, artigos técnicos e científicos e livros na biblioteca especializada da Fundacentro, a partir do indicador "benzeno" na chave de pesquisa livre desta biblioteca, priorizando a produção nacional. Foi utilizado também o instrumento desenvolvido pelo Ministério da Saúde em CD-ROM "Repertório Brasileiro do Benzeno", que compila experiências de ações relacionadas com a prevenção da exposição ao benzeno no Brasil, e têm 
também parte da produção técnico-científica brasileira e internacional, inclusive teses e dissertações, algumas delas escaneadas e que não são acessíveis de outra forma a não ser por este meio. Uma outra parte dos artigos revisados pertence aos arquivos pessoais do autor e de pesquisadores da Fundacentro e da Fiocruz, que apoiaram este trabalho de diversas formas, inclusive cedendo cópias de artigos.

A partir da revisão deste acervo foi identificada uma analogia importante entre a experiência internacional e a nacional, em relação ao benzeno, com várias semelhanças e outras tantas diferenças também significativas. Como se trata de períodos longos, em que muitas mudanças ocorreram, foi decidido classificar este percurso em ciclos. Tomou-se como base, inicialmente, a experiência internacional, devido ao maior número de referências existentes e à maior estabilidade desse processo histórico, que cursa num período de quase 190 anos, de 1820 a 2008.

Para definir os ciclos da experiência internacional foram usados como critérios as informações sobre o tipo de produção e uso do benzeno e os dados de exposição e agravos à saúde existentes. A partir destes critérios foram identificados quatro períodos na experiência internacional: um inicial de 1820 a 1900 em que há pouco uso do benzeno e apenas começam a se conhecer seus importantes potenciais de danos; o segundo, de 1900 a 1950, em que há grande difusão do uso, exposições a grandes concentrações e predominância de aplasias de medula como casos mais graves; o terceiro, de 1950 a 1990, em que começa a haver uma mudança nos padrões de uso, há uma diminuição nos 
padrões de exposição e uma mudança nos padrões de agravo com as leucemias substituindo as aplasias como quadro principal relacionado à exposição a benzeno; o quarto período começa em 1990 e vai até os dias de hoje, quando a discussão passa a girar em torno do risco da exposição a baixas concentrações de benzeno, e da preocupação quanto à exposição ambiental que se aproxima da exposição ocupacional.

Estes critérios, satisfatórios para classificar os ciclos da experiência internacional do benzeno foram, no entanto, difíceis de serem aplicados na experiência brasileira, apesar das várias semelhanças entre as duas, devido à falta de dados sobre exposição e agravos à saúde no Brasil. Para suprir estas lacunas o critério escolhido foi aquele definido como objetivo central do estudo, ou seja, a legislação de restrição à exposição, combinada, quando possível ou necessário, com os dados de produção e utilização de benzeno no Brasil. Com base nestes critérios também foram definidos quatro períodos, parecidos porém diferentes daqueles da experiência internacional. O primeiro, de 1932 a 1960, inicia com a primeira legislação de restrição à exposição ao benzeno, que proíbe o trabalho de mulheres em atividades que tenham risco de exposição a benzeno, e se encerra quando passamos a ter o registro da produção de benzeno no Brasil. O segundo período vai até 1982, quando é proibido o uso de benzeno em solventes. O terceiro período se encerra em 1994 com o reconhecimento do benzeno como substância cancerígena. O quarto período permanece até o presente momento. 
Foram também definidos quatro pontos de referência para serem examinados mais detidamente e servirem como parâmetros para a identificação de eventuais avanços ou retrocessos: as regulamentações legais, em especial, mas não apenas, a legislação federal; a qualificação, quando possível, da exposição dos trabalhadores, inclusive as quantitativas quando existentes; os agravos à saúde reconhecidos em cada um destes períodos; as ações de prevenção e proteção dos trabalhadores feita por empresas, órgãos públicos e sociedade civil.

A partir do levantamento feito foram identificados os elementos considerados mais relevantes, na experiência internacional e nacional, relacionados à exposição ocupacional ao benzeno. Estas informações foram organizadas na forma de relatos, sendo destacados alguns dos casos mais significativos e, no caso da experiência nacional, os pontos de referência elencados. Deste conjunto de dados e informações foram retirados os resultados apresentados aqui. 


\section{RESULTADOS}

A experiência internacional pode ser dividida em 4 períodos ou ciclos: um ciclo inicial, de 1820 até final do século XIX, em que apenas se começa a conhecer e utilizar o benzeno, mas seu potencial de danos à saúde dá seus primeiros e potentes sinais; o segundo, do início até aproximadamente metade do século $X X$, que compreende uma grande ampliação e difusão do uso industrial do benzeno e a consolidação do conhecimento de suas características como substância química notoriamente tóxica e cancerígena. Neste ciclo preponderam exposições a concentrações extremamente elevadas, há muito pouco controle ou medidas de restrição do uso, e as aplasias de medula são o agravo mais significativo e ocorrem relativamente com grande freqüência; um terceiro período, dos anos 1950 ao final dos anos 80, em que este uso permanece e se amplia, mas ao mesmo tempo se modifica, se introduzem restrições importantes em alguns países para sua utilização, há uma diminuição substantiva das concentrações ambientais que, no entanto, continuam importantes. A relação causal com a leucemia assume grande destaque, possivelmente em razão da diminuição das concentrações e consequentemente do tipo de agravo, a partir das experiências da Itália, Turquia, Estados Unidos e China, que se tornam referência mundial, apesar das grandes diferenças e assincronias entre si; e finalmente um quarto período, o período atual, em que a discussão da exposição ocupacional ao benzeno se confunde com a discussão da exposição ambiental. Neste período a questão 
passa a girar em torno dos riscos relacionados a exposições a baixas concentrações de benzeno, que passam a prevalecer nos ambientes de trabalho em que ainda há exposição potencial a benzeno e em que os estudos desenvolvidos principalmente na China, mas também em alguns outros países, fora do circuito da sociedade pós-industrial, apontam para a existência de agravos à saúde com exposições cada vez menores, identificando-se danos com contaminações ocupacionais próximas das ambientais.

À semelhança da experiência internacional, a experiência brasileira em relação ao benzeno também pode ser dividida em quatro períodos ou ciclos. Entre as muitas particularidades que a diferenciam, uma das mais importantes, possivelmente semelhante a outras sociedades com padrões de desenvolvimento econômico e industrial tardio como o brasileiro, é o fato destes períodos começarem também tardiamente, no caso do benzeno apenas nos anos 30 do século XX. E seus ciclos, principalmente os que sucedem o inicial, que é bastante formal, são extremamente curtos, provavelmente em conseqüência das repercussões dos determinantes econômicos e tecnológicos dos países centrais ou, dizendo de outra maneira, por ser quase uma repetição do que ocorreu naqueles países, mas de uma maneira específica, muito diferenciada e bastante acelerada. Do ponto de vista da saúde do trabalhador muitas coisas podem ser desentranhadas do lema "cinquenta anos em cinco" dos míticos anos "JK".

Em razão da dificuldade de se conseguir informações específicas sobre o uso e a exposição ao benzeno, e pela opção deste estudo de correlacionar os 
instrumentos legais estabelecidos para restrição da exposição ao benzeno com a prevenção da contaminação, o caminho escolhido para a classificação dos períodos foi baseado na combinação da criação dos instrumentos legais com o desenvolvimento da produção industrial e a adequação desses instrumentos a este processo.

O primeiro período, então, começa nos anos 30 e vai até meados dos anos 60 , e nele foram feitas as primeiras legislações sobre benzeno no Brasil, alguns anos antes de começarem as atividades industriais mais importantes relacionadas à produção de benzeno no Brasil: siderurgia em 1946 e petróleo e petroquímica na década de 50. Apesar do início destas atividades e das legislações existentes, no curso deste período não há relato conhecido de exposição importante a benzeno ou de agravos à saúde relacionados com esta exposição, embora certamente ambos devam ter ocorrido.

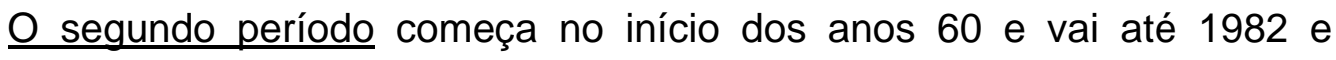
corresponde a um progressivo e extraordinário aumento da produção de benzeno e uma grande difusão de seu uso como solvente, sendo que estes fenômenos ocorreram de forma muito semelhante em outros países - inclusive nos países referência aqui descritos na experiência internacional que utilizamos como base - e se encerra com a proibição do benzeno nos solventes em 1982.

Neste período são identificados os primeiros casos de intoxicação crônica por benzeno em estudos hematológicos para investigação de aplasias de medula. Posteriormente aparecem relatos muito significativos de exposições bastante elevadas e agravos importantes, particularmente aplasias de medula 
em indústrias de equipamentos hospitalares e em indústrias de calçados, em que o benzeno foi usado como solvente. Não há relato de casos nas indústrias onde há produção de benzeno ou onde é utilizado como matéria prima. Tampouco há referência a casos de leucemia relacionados à exposição a benzeno. Neste período ainda surgem problemas importantes relacionados com a saúde do trabalhador em geral, mas também em relação ao benzeno, e novas legislações são criadas: em 1973 a aposentadoria especial, que inclui o benzeno, e em 1978 as Normas Regulamentadoras que estabelecem um Limite de Tolerância para o benzeno, dentre outras substâncias.A proibição da presença de benzeno em solventes restringiu em muito o grupo de empresas em que o benzeno era utilizado de forma significativa.

No terceiro período, a preocupação principal passou a ser a exposição ocupacional na indústria petroquímica e química de segunda geração, e também aqui a exposição dos trabalhadores da indústria siderúrgica a benzeno será bastante valorizada, pois esta é uma particularidade importante da experiência brasileira. Como na experiência internacional, ao longo deste período houve uma mudança nos padrões de exposição, que ainda assim se mantiveram altos, embora não como anteriormente, e houve muita polêmica e controvérsia sobre o significado das alterações encontradas e dos agravos que acometeriam ou não os trabalhadores. Este é um período de grandes transformações no mundo do trabalho no Brasil e a luta pela saúde dos trabalhadores terá uma contribuição muito importante neste processo. Uma parte destacada desta luta será travada em torno da exposição e das doenças 
provocadas pelo benzeno, que serão finalmente desveladas. Este período se estende até 1994, quando houve o reconhecimento pelo Ministério do Trabalho do benzeno como substância cancerígena, dando início ao quarto período que permanece até o presente momento.

Neste quarto período há uma mudança de abordagem significativa tanto do ponto de vista da exposição ao benzeno em si, como da forma de tratamento da vigilância dos riscos e da importância ambiental da substância, levando a novos desafios, boa parte deles ainda não equacionados. Este período se caracteriza por uma pactuação nacional inédita envolvendo representações nacionais de três setores da sociedade: uma parte importante do poder público, empresários e trabalhadores. Esta pactuação se deu em torno de alguns princípios dentre os quais destacamos: a proibição da utilização do benzeno permitindo seu uso apenas em alguns setores industriais e sob permissão específica; o abandono do conceito de limite de tolerância e a adoção do princípio de não exposição, com a apropriação do conceito de valor de referência tecnológico VRT; a valorização das formas de participação dos trabalhadores como estratégias efetivas de prevenção de riscos.

O quadro a seguir apresenta o histórico da regulamentação do benzeno no Brasil, de 1932 até os dias de hoje. 
Quadro 1 - Histórico referente à regulamentação do benzeno no Brasil

\begin{tabular}{|c|c|}
\hline Ano & Legislação \\
\hline 1932 & $\begin{array}{l}\text { Proibição do trabalho da mulher em atividades perigosas e } \\
\text { insalubres. }\end{array}$ \\
\hline 1939 & $\begin{array}{l}\text { Definição da atividade com benzeno como perigosa e insalubre, } \\
\text { implicando no pagamento de adicional de insalubridade. }\end{array}$ \\
\hline 1943 & $\begin{array}{l}\text { Proibição do trabalho do menor com benzeno, seus homólogos e } \\
\text { derivados. }\end{array}$ \\
\hline 1973 & $\begin{array}{l}\text { Instituição da aposentadoria especial para trabalhadores com } \\
\text { exposição ao benzeno durante } 25 \text { anos. }\end{array}$ \\
\hline 1978 & $\begin{array}{l}\text { NR } 15 \text { - Anexo 11: estabelecimento do Limite de Tolerância de } 8 \\
\text { ppm e do Valor máximo de } 16 \text { ppm para o benzeno. }\end{array}$ \\
\hline 1982 & $\begin{array}{l}\text { Portaria Interministerial } n^{\circ} 3 \text { : proibição do benzeno em produtos } \\
\text { acabados e estabelecimento de limite máximo de } 1 \% \text { em volume } \\
\text { como contaminante. }\end{array}$ \\
\hline 1983 & $\begin{array}{l}\text { NR 7: estabelecimento de Limite de tolerância Biológico (50 mg de } \\
\text { fenol por litro de urina) e Valor normal ( } 30 \mathrm{mg} \text { de fenol por litro de } \\
\text { urina). } \\
\text { Circular no } 297 \text { do INAMPS da Secretaria Regional de Medicina } \\
\text { Social de São Paulo: estabelecimento de "Critérios para } \\
\text { caracterização de leucopenia". }\end{array}$ \\
\hline 1986 & $\begin{array}{l}\text { Secretaria de Saúde do Estado de São Paulo: inclusão de } \\
\text { alterações hematológicas para exposição ao benzeno no Sistema } \\
\text { de Vigilância Epidemiológica de Doenças Ocupacionais. }\end{array}$ \\
\hline 1987 & $\begin{array}{l}\text { Secretaria Regional de Medicina Social do Rio de Janeiro: } \\
\text { estabelecimento dos mesmos critérios de São Paulo em caráter } \\
\text { provisório. }\end{array}$ \\
\hline
\end{tabular}




\begin{tabular}{|c|c|}
\hline 1991 & $\begin{array}{l}\text { Seminário de Grupo Interinstitucional na Bahia: proposta de um } \\
\text { "Protocolo de Intenções para controle do Benzenismo e outras } \\
\text { doenças Ocupacionais do Pólo Petroquímico de Camaçari". } \\
\text { Rio Grande do Sul: criação do "Comitê Estadual do Benzeno". } \\
\text { Secretaria de Estado da Saúde de SP: criação da "Norma Técnica } \\
\text { de Diagnóstico e Controle da Exposição ao Benzeno". }\end{array}$ \\
\hline 1992 & $\begin{array}{l}\text { Outros estados, entre eles Minas Gerais e alguns municípios, como } \\
\text { Santo André (SP), criam normas e regulamentos sobre o } \\
\text { diagnóstico e o controle da exposição ao benzeno. }\end{array}$ \\
\hline $\begin{array}{l}\text { Março de } \\
1993\end{array}$ & $\begin{array}{l}\text { Seminário Nacional sobre exposição ao benzeno e outros } \\
\text { mielotóxicos em Belo Horizonte: sugestões de modificação das leis } \\
\text { previdenciárias e trabalhistas relacionadas ao benzeno. }\end{array}$ \\
\hline $\begin{array}{l}\text { Junho de } \\
1993\end{array}$ & $\begin{array}{l}\text { Ministério da Previdência Social: estabelecimento de "Norma } \\
\text { técnica sobre a Intoxicação ao Benzeno". } \\
\text { Revisão da Norma Regulamentadora no15, e criação do Grupo de } \\
\text { Trabalho Técnico, que elabora o documento "Benzeno - Subsídios } \\
\text { Técnicos à Secretaria de Segurança e Saúde no Trabalho". }\end{array}$ \\
\hline 1994 & $\begin{array}{l}\text { Portaria no3 Ministério do Trabalho e Emprego: reconhecimento do } \\
\text { benzeno como substância cancerígena, implicando que nenhuma } \\
\text { exposição humana fosse permitida. }\end{array}$ \\
\hline $\begin{array}{l}\text { Dezembro } \\
\text { de } 1995\end{array}$ & $\begin{array}{l}\text { Acordo Nacional do Benzeno. } \\
\text { Portaria no14 - Ministério do Trabalho: criação do Anexo 13A } \\
\text { específico sobre o benzeno } \\
\text { Instruções normativas no } 1 \text { e } 2 \text { da Secretaria de Segurança e } \\
\text { Saúde no Trabalho, do Ministério do Trabalho: avaliação ambiental } \\
\text { e vigilância à saúde dos trabalhadores expostos. }\end{array}$ \\
\hline 1996 & $\begin{array}{l}\text { Portaria no1 - Ministério do Trabalho: instalação da Comissão } \\
\text { Nacional Permanente do Benzeno }\end{array}$ \\
\hline 1998 & $\begin{array}{l}\text { Portaria no27: estabelecimento de prazos para substituição do } \\
\text { benzeno na produção de álcool anidro }\end{array}$ \\
\hline
\end{tabular}




\begin{tabular}{|c|c|}
\hline 2001 & $\begin{array}{l}\text { Portaria @33: consulta pública para redução do teor de benzeno em } \\
\text { produto acabado } \\
\text { Portaria n³4: determinação dos procedimentos para a utilização } \\
\text { de indicador biológico de exposição ao benzeno } \\
\text { Portaria no309 da Agência Nacional do Petróleo: estabelecimento } \\
\text { de teor máximo de benzeno em 1\% na gasolina comum tipo C. }\end{array}$ \\
\hline $\begin{array}{l}\text { Março de } \\
2002\end{array}$ & $\begin{array}{l}\text { Portaria n5: adiamento da consulta pública sobre benzeno em } \\
\text { produto acabado }\end{array}$ \\
\hline $\begin{array}{l}\text { Dezembro } \\
\text { de } 2002\end{array}$ & $\begin{array}{l}\text { Nota técnica da Coordenação de Registros da Secretaria de } \\
\text { Inspeção do Trabalho: define a abrangência do campo de } \\
\text { aplicação do acordo e legislação do benzeno }\end{array}$ \\
\hline $\begin{array}{l}\text { Setembro } \\
\text { de } 2003\end{array}$ & $\begin{array}{l}\text { Resolução RDC nำ252 da ANVISA: adoção do controle de benzeno } \\
\text { em produtos cadastrados pela ANVISA }\end{array}$ \\
\hline \multirow[t]{3}{*}{2004} & $\begin{array}{l}\text { Portaria interministerial nำ775: proibição da comercialização de } \\
\text { produtos acabados que contenham benzeno em sua composição, } \\
\text { admitindo, porém, alguns percentuais. }\end{array}$ \\
\hline & $\begin{array}{l}\text { Portaria no } 776 \text { do Ministério da Saúde: dispõe sobre a } \\
\text { regulamentação dos procedimentos relativos à vigilância da saúde } \\
\text { dos trabalhadores expostos ao benzeno, e dá outras providências. }\end{array}$ \\
\hline & $\begin{array}{l}\text { Nota técnica no } 30 \text { do DSST: revisão do capítulo V do Acordo } \\
\text { Nacional do Benzeno "Da Participação dos Trabalhadores" }\end{array}$ \\
\hline 2005 & $\begin{array}{l}\text { Instrução Normativa nº1 da Secretaria de Vigilância à saúde do } \\
\text { Ministério da Saúde: regulamentação da Portaria MS no } 1.172 / 2004 \\
\text { no que se refere às competências na área de vigilância em saúde } \\
\text { ambiental. }\end{array}$ \\
\hline
\end{tabular}

Fontes: Novaes, 1992; Magrini, 1999; Arcuri e Cardoso, 2005; Corrêa, 2008 


\subsection{A Experiência Internacional}

\subsubsection{Os primeiros achados no século XIX}

A descoberta da química orgânica e das possibilidades de seu uso na industria ocorreu no final da revolução industrial, na década de 1820. Já em 1830 foram feitas as primeiras regulamentações na Inglaterra para enfrentar os problemas no uso industrial do ácido clorídrico que causava grande incômodo aos vizinhos e destruía a vegetação nas redondezas das fábricas. Porém, a grande ampliação da utilização das substâncias orgânicas se deu sobretudo na Inglaterra a partir de 1850 , e se deve principalmente aos avanços na extração de substâncias químicas do carvão mineral e às possibilidades de utilizar os primeiros corantes de anilina, em 1856, que impulsionaram o desenvolvimento da destilação de carvão mineral em larga escala para produzir hidrocarbonetos aromáticos e fenóis. Os corantes sintéticos praticamente substituíram os corantes naturais usados durante milênios, e eram manufaturados a partir de matérias primas da destilação do carvão mineral, das quais as principais eram benzeno, naftaleno, tolueno e antraceno. Estas substâncias, relativamente simples, constituíram a base para uma ampla gama de intermediários mais complexos que possibilitaram o crescimento da industria química na segunda metade do século XIX, período em que a Inglaterra era a "fábrica do mundo" (Hunter, 1955).

É deste período o primeiro relato de intoxicação aguda por benzeno, que data de 1862 na Inglaterra, e refere a ocorrência de um caso de ingestão 
acidental de benzeno seguida de inconsciência e morte do trabalhador. A necropsia mostrou cérebro, pulmões e fígado cheios de sangue. Em 1889, também na Inglaterra, foi relatado o caso de um homem que engoliu acidentalmente benzeno líquido, ficou inconsciente, foi hospitalizado e salvo. A hematotoxidade do benzeno, no entanto, foi identificada somente no final do século XIX, na indústria de borracha, com o achado de 9 casos de aplasia de medula em jovens trabalhadoras por Santessen, em 1897: elas atuavam na fabricação de pneus de bicicleta na Suécia, e 4 delas morreram. No mesmo ano, foi relatado por LeNoir e Claude um caso de hemorragia em um jovem trabalhador de lavagem a seco na França, que também foi a óbito com suspeita de leucemia, possivelmente linfóide, devido à grande quantidade de leucócitos encontrados no seu sangue periférico. Desde então o benzeno passou a ser conhecido pela sua toxicidade para a medula óssea. (Hunter, 1955; Aksoy, 1987).

\subsubsection{A primeira metade do século $X X$}

A expansão do uso industrial do benzeno no início do século $X X$, como solvente na indústria de borracha antes da guerra e como componente do tolueno na produção de explosivos durante a primeira guerra mundial, se ampliou ainda mais no pós-guerra, com o grande aumento de sua utilização em inúmeros processos industriais: como solvente na produção de couro artificial, produtos de borracha, colas, manufatura de chapéus, impressão por rotogravura, pintura, adesivos, revestimentos, lavagem a seco, produção de 
automóveis e montagem de latas; como matéria prima na síntese de produtos orgânicos derivados do petróleo e na mistura de combustíveis para motores. Ao aumento da sua utilização correspondeu uma elevação do número de achados de casos de doenças relacionados com a exposição ao benzeno, em geral referidos como Intoxicação por Benzeno (Infante, 2002).

Em 1910 foram relatados por Selling, em Baltimore, os primeiros casos de intoxicação crônica por benzeno identificados nos Estados Unidos. Eram casos graves diagnosticados como Púrpura Hemorrágica em trabalhadoras de uma fábrica de latas que utilizava uma preparação adesiva à base de benzeno para selar as latas. De 14 meninas entre 14 e 16 anos que trabalhavam nessa atividade, 3 foram internadas com diagnóstico de Púrpura no Hospital John Hopkins. Duas morreram e tiveram identificada aplasia severa em suas medulas, a terceira sobreviveu. Selling conhecia o trabalho de Santessen, e fez pesquisas com coelhos nos quais aplicava benzeno subcutâneo, provocando queda de leucócitos e morte com aplasia de medula, o que permitiu a Selling validar as sugestões de Santessen. Um patologista americano, Weiskotten, em 1920, também fez pesquisas em coelhos, desta vez expondo os animais à inalação de altas concentrações de benzeno, provocando queda importante das células sanguíneas circulantes. Estes achados pioneiros estabeleceram a relação direta entre exposição a benzeno e aplasia de medula (Hunter, 1955; Aksoy, 1987; Snyder, 2002).

Ainda nos Estados Unidos, na década de 20, inúmeros casos de intoxicação por benzeno foram identificados, alguns intoxicados com poucas 
semanas de trabalho, outros mortos após alguns meses de exposição. Greenburg e seus colaboradores fizeram um levantamento em 12 fábricas que usavam benzeno, encontrando $32 \%$ dos trabalhadores com número de leucócitos diminuídos (abaixo de 5.500 células), sendo 12\% com leucócitos abaixo de 4.000. As exposições eram da ordem de 90 ppm (partes por milhão) e os pesquisadores indicavam afastamento médico se 0 trabalhador apresentasse sinais de intoxicação clínica, ou se os valores individuais das contagens sanguíneas caíssem $25 \%$ ou mais. Os estudos de Greenburg apontaram a grande variedade de alterações hematológicas que a exposição a benzeno podia produzir (Aksoy, 1987; Infante, 2002).

A relação direta entre a exposição a benzeno e a destruição da medula óssea com plaquetopenia, granulocitopenia e finalmente a diminuição das células vermelhas ficou claramente estabelecida, embora com uma visão dos danos hematológicos ainda limitada. A Dra. Alice Hamilton foi a primeira a criticar a visão excessivamente simplificada do quadro clínico e hematológico da intoxicação por benzeno existente na época, sugerindo que a intoxicação crônica por benzeno era semelhante àquela provocada pela exposição a radium e a raios $X$, podendo ser responsável por achados hematológicos e clínicos bem mais variados assim como da própria medula óssea. Pioneira na área de prevenção de riscos no trabalho nos Estados Unidos, começou em 1922 uma campanha para aumentar as medidas de segurança nas áreas que usavam benzeno, tendo sido bem sucedida com a substituição do benzeno por tolueno e nafta de petróleo em diversas atividades. No entanto, neste mesmo período, 
outros usos do benzeno foram sendo descobertos, mantendo ainda por várias décadas o risco da exposição ao benzeno, ainda que de forma diferenciada devido à introdução de medidas de proteção e prevenção da exposição, como ventilação adequada e substituição do benzeno quando possível. (Hunter, 1955; Aksoy, 1987; Barale, 1995).

Na Europa, em 1928, foi relatado pela primeira vez um caso com diagnóstico consolidado de leucemia relacionado com exposição ao benzeno, por Dolore e Borgomano na França, consolidando já naquela época o conhecimento sobre os principais agravos à saúde relacionados ao benzeno. Em recuperação histórica de casos relatados na Europa, feita por M. Savilahti em 1956, foram identificadas diversas situações graves: Hunter reportou em 1939 a morte de 10 trabalhadores, entre 89 pacientes pancitopênicos com exposição crônica a benzeno na Inglaterra; na Alemanha, 164 casos de aplasia de medula induzida por benzeno foram encontrados entre 1913 e 1928, sendo 27 deles fatais; Nilsby, na Suécia, em 1949, estudou 7 casos, dos quais 6 foram fatais; outro relato na Suécia, de Helmer, em 1944, mostrou 2 casos de morte entre 60 trabalhadores intoxicados. (Hunter, 1955; Aksoy, 1978; Aksoy, 1987; Infante, 2002).

Este conhecimento vem se reafirmando e desenvolvendo ao longo dos anos, sendo hoje uma das discussões centrais os efeitos do benzeno em baixas concentrações, em razão das mudanças do padrão de exposição que ocorreram nessas décadas (Snyder, 2002). Essas mudanças começaram na década de 30, a partir da identificação da carcinogenicidade do benzeno, mas 
passaram a ter mais impacto a partir dos anos 50 , pois houve um refluxo deste processo durante o período da II Guerra Mundial. Ainda em 1939 vários pesquisadores propuseram a substituição do benzeno por outros solventes. Apesar disso a American Conference of Governamental Industrial Hygienists (ACGIH) recomendou em 1946 um limite de 100 ppm para exposição a benzeno nos locais de trabalho, diminuindo esse valor, no ano seguinte, para 50 ppm, e depois para 35 ppm, em 1948. Nesse mesmo ano, devido às evidências de "hipersuscetibilidade" da medula óssea aos efeitos supressores do benzeno, o American Petroleum Institute (API) concluiu que o único nível seguro de exposição a benzeno seria zero, mas recomendou um limite de 50 ppm ou menos (Infante, 2002).

\subsubsection{O terceiro ciclo}

Ao período do pós-guerra, entre 1945 e 1970, corresponde um aumento extraordinário da utilização do petróleo. Enquanto o consumo mundial de energia triplicou entre 1949 e 1972, o que por si só mostra o crescimento ocorrido nesse período, o consumo de petróleo cresceu mais de cinco vezes. É nesse período que ocorre a transição da produção de benzeno, que até então era extraído principalmente nos setores de carboquímicos das usinas siderúrgicas, que produziam substâncias químicas com base no processo de transformação do carvão em coque, aproveitando o gás de coqueria resultante desse processo - e que passa a ser produzido a partir do petróleo de forma preponderante e a ser um produto da industria petroquímica. 
Nestes "anos dourados" de grande expansão da produção industrial e do consumo em boa parte do planeta, o petróleo se tornou a principal base material, tanto como combustível quanto como matéria prima, para a indústria petroquímica e suas cadeias produtivas principais: indústrias químicas, de borracha e de plásticos. Neste período histórico marcante, ao mesmo tempo em que há um grande desenvolvimento tecnológico, ocorre uma valorização significativa do trabalho e dos trabalhadores, com um aumento correspondente da preocupação com a implantação de medidas de prevenção de riscos nas atividades laborais e proteção dos trabalhadores, em particular na Europa, Estados Unidos e União Soviética (Yergin, 1992; Hobsbawn, 1996).

\section{A Experiência Italiana}

\section{Os achados de Intoxicação por benzeno na Itália}

É então a partir dos anos 50 que aumentam os achados que relacionam a exposição ao benzeno com leucemia, e estes estudos passam a se intensificar. Dentre eles se destacam os realizados na Itália por Vigliani e Forni e na Turquia por Aksoy, que constituem a casuística mais ampla e significativa neste período e que contribuem de forma notável para a consolidação do reconhecimento da existência dos efeitos mielotóxicos e leucemogênicos do benzeno (Bartolucci, 1995).

Na Itália, já a partir dos anos 20, em razão de exposições a altíssimas concentrações de benzeno, haviam sido identificadas verdadeiras epidemias de intoxicações por benzeno agudas e crônicas. Em revisão feita por Vigliani e 
Forni em 1976 foram recuperados dados dos primeiros casos identificados naquele país, entre 1928 e 1938: 60 casos de aplasia de medula em trabalhadores da industria de calçados, tipografias e outras industrias que usavam benzeno como solvente. São também descritos 10 casos de leucemia e 4 casos não classificados na época, mas que depois foram identificados como possíveis Síndromes Mielodisplásicas. Entre 1942 e 1975 em Milão foram observados 66 casos de hematopatias por exposição a benzeno, com exposições estimadas entre 200 e 400 ppm, dos quais 7 morreram com aplasia de medula. Em Pavia, entre 1959 e 1974, foram diagnosticados 135 casos de benzolismo, 3 deles com aplasias fatais, com exposições entre 25 e 600 ppm. Foi estimado nesta população um risco de desenvolver leucemia 20 vezes maior que na população geral; foram identificados 13 casos de leucemia em Pavia e 11 em Milão (Bartolucci, 1995; Aksoy, 1987).

Em 1989, Vai e colaboradores revisaram e atualizaram a casuística dos casos de atendimentos por "suspeita de tecnopatia por benzeno" na Clinica del Lavoro de Milão e no Instituto de Medicina del Lavoro de Pavia entre 1951 e 1970, do primeiro ano que havia arquivos disponíveis até o último ano em que houve internações por benzenismo crônico. A análise da mortalidade de 295 pacientes no período de 1950 a 1986 encontrou um aumento significativo das mortes por neoplasias hematológicas e por doenças sanguíneas. Por disporem de anamneses ocupacionais bem elaboradas, foi possível classificar os sujeitos em três grupos de exposição (menos de 20 ppm, de 20 a 60 ppm, mais de 60 ppm), o que permitiu relacionar o tipo de patologia com os níveis de exposição, 
evidenciando a relação da exposição a altas concentrações com a ocorrência de casos mais graves (Bartolucci, 1995).

Outro estudo foi publicado em 1989 por Paci e colaboradores: um levantamento retrospectivo foi feito em Florença para avaliar a mortalidade numa coorte de trabalhadores da indústria de calçados expostos a benzeno entre 1939 e 1984. Foi evidenciado um aumento da mortalidade por anemia aplástica e leucemia, todos os casos tendo ocorrido entre trabalhadores que haviam trabalhado no período anterior a 1963. Naquele ano foi estabelecida na Itália uma lei que limitava o uso do benzeno como solvente, determinando ainda outras imposições que, junto com a melhora dos ambientes de trabalho, resultou numa redução notável da incidência de casos de intoxicação por benzeno na industria; permaneceu ainda uma diferença na exposição dependendo do tipo de industria e mesmo exposições mais significativas em situações específicas em que a lei não foi respeitada. (Bartolucci, 1995).

A lei no 245, de 05/03/1963, que limitava o uso do benzeno e seus homólogos nas atividades laborais, foi ampliada em 1965 com o reconhecimento do benzeno enquanto patôgeno e cancerígeno, e em 1976 com a proibição do trabalho de mulheres e adolescentes em situação de risco de exposição ao benzeno. A discussão de substituição do benzeno foi bastante relevante nesse período tendo sido publicado, em 1968, guia da Organização Internacional do Trabalho orientando quanto ao uso, riscos e substituição do benzeno (Alessio, 1981). 
Há evidências significativas de uma mudança progressiva, com uma diminuição substantiva nos padrões de exposição, que corresponde a mudanças nos tipos de achados patológicos e posteriormente a uma diminuição dos achados. Há estimativas de uma diminuição da exposição na Itália na segunda metade dos anos 60 de até 100 vezes na contaminação ambiental, principalmente na industria de calçados, impressão e borracha. Vigliani e Forni haviam relatado na industria de calçados exposições entre 100 e 2000 mg/m³, na impressão entre $30-3500 \mathrm{mg} / \mathrm{m}^{3}$ e na borracha entre 64 a $80 \mathrm{mg} / \mathrm{m}^{3}$. Logo após a entrada em vigor da lei 245/63, nas mesmas fábricas o nível médio de contaminação caiu para $2-40 \mathrm{mg} / \mathrm{m}^{3}$ nos calçados, $0,1-2 \mathrm{mg} / \mathrm{m}^{3}$ na impressão e 0,1-2 $\mathrm{mg} / \mathrm{m}^{3}$ na borracha. Nos anos seguintes estas quedas continuaram, pois se nos anos 70 ainda se usava tolueno e ocorria de se encontrar benzeno contaminando esse produto, a partir dos anos 80 o uso desta substância caiu vertiginosamente, sendo substituída por outras substâncias, por motivos econômicos e tecnológicos. Ao mesmo tempo em que há esta queda evidente, alguns achados de benzeno em locais "inesperados" como setores de histologia e anatomia patológica de hospitais, estampagem de matéria plástica e fabricação de tecidos adesivos chamam a atenção (Cocheo, 1995).

No entanto a diminuição das concentrações ambientais e a diminuição de achados de casos implicaram numa diminuição da importância do benzeno; assim, as pesquisas sobre sua presença e impacto na saúde na Itália praticamente acabaram neste período, sendo substituídas por estudos de exposição a solventes múltiplos. Nos anos 90 uma nova preocupação com o 
benzeno apareceu, desta vez com uma mudança de enfoque, valorizando a questão ambiental em razão da contaminação do ar pelos combustíveis dos automóveis e o comprometimento da saúde da população em geral. Neste novo contexto a valorização da contaminação por benzeno provocada pelo cigarro também adquire nova importância já que os elevados níveis de contaminação anteriores agora deram lugar a patamares de contaminação bem menores (Apostoli e Alessio, 1995).

\section{Algumas lições e questões da experiência italiana}

- Embora os primeiros achados remontem aos anos 30 , os principais ocorrem no pós-guerra, resultando principalmente da grande expansão do uso como solvente que o benzeno passou a ter, mas também da significativa capacidade técnica de intervenção e diagnóstico de casos existente na Medicina do Trabalho italiana, no caso particular em Milão e Pavia, assim como da força da organização social dos trabalhadores naquele período.

- Assim como é possível identificar a ocorrência de agravos com a difusão do uso do benzeno, é possível identificar uma mudança no padrão de morbidade com a mudança dos padrões de exposição, o que também ocorre em outras experiências, anteriores e posteriores, em outras nações. Neste caso, é bastante nítido o impacto positivo das medidas de restrição da exposição e proteção dos trabalhadores.

- Houve uma diminuição do uso do benzeno mas também uma diminuição dos estudos e investigações, certamente porque houve menos 
impacto e menos agravos com essa diminuição. No entanto, esta não é uma questão bem resolvida, já que posteriormente voltou a ser valorizada a exposição a baixas concentrações de benzeno.

- Fica a indagação se não se trata de um problema de uma sociedade pós-industrial.

\section{A Experiência da Turquia}

Na Turquia o clínico e hematologista Muzaffar Aksoy e seus colegas da Escola de Medicina de Istambul investigaram os impactos da introdução de um tipo de cola contendo benzeno na produção de calçados, identificando 40 casos de aplasia de medula ligados à exposição a benzeno entre 1961 e 1972 em Istambul. Pouco depois, entre 1967 e 1975, foram identificados 40 casos de exposição a benzeno em pacientes leucêmicos tratados no departamento de hematologia da Escola de Medicina de Istambul. Estas populações continuaram a ser investigados nos anos 70 e 80 e os achados destes estudos constituem os primeiros estudos epidemiológicos que comprovaram a relação entre benzeno e leucemia. O benzeno começou a ser usado depois de 1955 em Istambul e na Turquia, e é a partir de 1961 que começam a ser identificados casos de aplasia de medula relacionados com a exposição a benzeno. Alguns anos antes os trabalhadores na industria de sapato descobriram que colas com benzeno eram muito mais eficientes e baratas e começaram a usá-las. (Aksoy 1978; Aksoy, 1985; Aksoy, 1987) 
Em 1971, Aksoy publicou um estudo com 217 trabalhadores aparentemente saudáveis, em sua maioria da industria de calçados. Estavam expostos a concentrações de benzeno entre 30 e 210 ppm (com raros picos de 650 ppm), e as colas continham entre 9 e $88 \%$ de benzeno (com uma média de 50\%), no período de 1970 a 1972. Dos 217 trabalhadores, 51 (23,5\%) tinham alterações hematológicas como leucopenia (9,7\%), plaquetopenia $(1,84 \%)$, leucopenia + plaquetopenia $(4,6 \%)$, pancitopenia $(2,76 \%)$ e anomalia de Pelguer adquirida (0,46\%). Depois de 1971, 32 trabalhadores pancitopenicos expostos a benzeno por períodos de 4 meses a 15 anos foram estudados por Aksoy e colaboradores. Foram divididos em 4 grupos de acordo com os achados em sua medula óssea: pancitopenia com medula hipocelular ou aplásica (12 pacientes); pancitopenia com medula hiperplásica (7 casos); pancitopenia com medula normoplásica (12 pacientes) e pancitopenia com precursores eritróides gigantes, característico de préleucemia (1 paciente). 0 acompanhamento, com a revisão da mortalidade, foi relatado posteriormente, mostrando o desenvolvimento de leucemia em 44 paciente pancitopênicos com intoxicação crônica por benzeno. Neste grupo houve remissão completa em 23 pacientes $(52,35)$ e êxito letal devido a complicações da pancitopenia em 14 pacientes $(31,8 \%)$. Em seis pacientes houve desenvolvimento de leucemia depois de um período de 6 meses e 6 anos (13,6\%) (Aksoy, 1985; Aksoy, 1987).

Um estudo epidemiológico em 28.500 trabalhadores da fabricação de calçados, chinelos e bolsas com exposição crônica a benzeno, em Istambul, 
no período entre 1967 e 1975, mostrou que havia claramente um aumento do risco de leucemia. Dos 40 pacientes com leucemia e exposição a benzeno admitidos no serviço de hematologia da Escola de Medicina de Istambul naquele período, 34 eram parte dessa população. A incidência bruta neste grupo foi de 13,59 por 100.000 , significativamente maior do que o esperado. Essa incidência provavelmente era ainda subestimada, por não incluir trabalhadores deste grupo com leucemia atendidos em outros hospitais, e mesmo por que o grupo de expostos podia ser ainda potencialmente maior (Aksoy, 1985; Aksoy, 1987).

\section{Pontos importantes da experiência da Turquia}

Os estudos de Aksoy e colaboradores em Istambul, assim como os de Vigliani e Forni em Milão e Pavia, são clássicos e foram determinantes na comprovação da relação entre exposição a benzeno e leucemia, sendo referência mundial até hoje. A riqueza de detalhes e a familiaridade com que a população estudada é tratada são possivelmente resultado da tradição clínica desta escola e são evidentes nas inúmeras descrições feitas por Aksoy. É marcante o impacto que a introdução da utilização do benzeno teve no povo trabalhador de Istambul e talvez este seja um dos motivos da importância destes estudos: a visibilidade destes agravos na cidade de Istambul, possibilitada também pela evidente qualificação da formação hematológica do Professor Aksoy e sua equipe. Em quantas outras cidades e países o mesmo fenômeno ocorreu com a expansão do uso do benzeno? 
É também bastante curioso, e certamente não deixa de ter suas razões históricas, vale dizer sociais, políticas e econômicas, que questões que estavam em discussão acirrada nos países centrais e industrializados vieram a ter comprovação em país periférico e não industrializado, em atividade semiartesanal. Talvez seja esta distância do centro, combinada com a proximidade com o trabalhador e uma medicina mais humanizada, que tenha permitido este momento histórico na prevenção da exposição a benzeno.

\section{De volta aos Estados Unidos}

Assim como no início do século $X X$, nos anos 70 muita coisa significativa aconteceu em relação à exposição ao benzeno nos Estados Unidos, em particular em relação à definição quanto aos Limites de Tolerância aceitos para esta substância. No período do pós-guerra ocorreu uma mudança nos padrões de utilização do benzeno que passou a ser preponderantemente de origem petroquímica e ter vasta utilização como matéria prima para inúmeros produtos desta cadeia produtiva. As concentrações ambientais diminuíram, assim como as exposições, e novas questões vieram à tona.

Os Limites de Tolerância (Threshold Limit Values - TLVs) publicados pela American Conference of Governmental Industrial Hygienists (ACGIH) tinham muita influencia no mundo inteiro apesar de, em especial para as substâncias químicas, as evidências científicas que lhe davam suporte serem bastante questionáveis. Castleman e Ziem, em artigo notável de 1988, apontaram e circunstanciaram a participação decisiva das corporações na definição destes 
índices, que expressavam muito mais as concentrações ambientais já praticadas nos ambientes de trabalho das empresas ligadas a estas corporações do que quaisquer estudos técnicos que de fato trouxessem evidências de não ocorrência de danos à saúde dos trabalhadores expostos. (Castleman e Ziem, 1988).

O Comitê de TLV era a instancia da ACGIH responsável por estabelecer as suas propostas de limites. A ACGIH era uma organização voluntária, o que hoje é conhecido como organização não governamental, já naquela época sem vínculos formais com o governo dos Estados Unidos, apesar do nome (American Conference of Governmental Industrial Hygienists). Seus membros inicialmente eram funcionários federais, estaduais e municipais e, com o tempo, pesquisadores e consultores de industrias também foram incluídos. Uma das substâncias destacadas no trabalho de Castleman e Ziem foi o benzeno. O TLV para o benzeno foi sendo progressivamente ajustado para baixo: de 100 ppm em 1946, para 50 ppm em 1947, 35 ppm em 1948, e 25 ppm em 1957. O Comitê de TLV adotou 25 ppm como valor teto em 1963 - valor teto significava um valor que não poderia ser excedido em momento algum durante a jornada de trabalho. Um consenso entre as industrias propôs um "padrão" de 10 ppm com picos diários de no máximo 10 minutos a 50 ppm, em 1969, pelo American National Standards Institute. Em conseqüência disto, 10 ppm foi o primeiro limite adotado pela Ocupational Safety and Health Administration (OSHA) organização oficial do governo federal americano, reguladora da legislação de saúde e segurança no trabalho, ligada ao órgão equivalente aos Ministérios do 
Trabalho em outros países do mundo, chamado nos Estados Unidos de Work Department (Departamento do Trabalho). O governo e a industria inglesa propuseram ao Comitê de TLV da ACGIH que abandonasse o teto de 25 ppm pela média de 10 ppm já em 1966. O Comitê propôs esta mudança em 1968, mas derrogou sua adoção até 1977. Hueper havia avaliado o benzeno como quase certamente uma causa comprovada de leucemia em 1942. A Comissão alemã de MAK havia listado o benzeno em 1971 entre 9 cancerígenos humanos "para os quais é estabelecido concentração zero pois a concentração em que não ocorrem agravos não é conhecida". O benzeno foi classificado como "suspeito" de ser cancerígeno para humanos em 1975 pelo Comitê (Castleman e Ziem, 1988)

Um levantamento feito por Bo Holmberg e Per Lundberg para a Conferencia Internacional sobre Benzeno realizada pelo Collegium Ramazzini em 3 e 4 de novembro de 1983, mostrou que o valor permitido de benzeno em diversos países variava entre 5 e 10 ppm MPT (média ponderada no tempo). Muitos paises também haviam listado o benzeno como cancerígeno. $\mathrm{Na}$ Alemanha Ocidental (a Alemanha ainda era ainda dividida na época) não havia valor limite para substâncias cancerígenas como o benzeno, mas "referências técnicas". O valor de referência técnica para o benzeno em 1974 era 8 ppm. O critério científico para classificar o benzeno como cancerígeno foi baseado na ocorrência de leucemia, alterações cromossomiais em trabalhadores e leucopenia e outras alterações sanguíneas em animais expostos a benzeno. $\mathrm{Na}$ União Soviética, em 1982, a Concentração Máxima Aceitável (MAC) de 
benzeno no ar na área de trabalho era de 1,3 ppm (área de trabalho era definida como o espaço até 2 metros acima do nível onde os trabalhadores estavam). A ACGIH, em documentação de 1980, afirmava haver pouca evidência que a exposição a benzeno a concentrações abaixo de 25 ppm provocasse discrasias sanguíneas. Na Suécia o valor de 5 ppm foi estabelecido em 1978, com um valor de curta duração de 10 ppm por 15 minutos. A Organização Internacional do Trabalho adotou um valor teto de 25 ppm em 1971, recomendado aos países membros, com a substituição do benzeno obrigatória sempre e onde fosse possível. A Agência Internacional de Pesquisa do Câncer (IARC) em 1982 concluiu haver evidência suficiente que o benzeno era cancerígeno para o homem. Na época ainda não havia comprovação em estudos experimentais com animais, o que já ocorreria no ano seguinte com os estudos de César Maltoni em Bolonha (Holmberg, 1985)

Ainda na Conferencia Internacional sobre Benzeno do Collegium Ramazzini de 1983, Peter Infante e Mary White apresentaram seus estudos sobre a avaliação quantitativa do risco de leucemia associado à exposição a benzeno, que fundamentaram a defesa da OSHA no processo de mudança do limite de tolerância. Embora algumas centenas de casos de leucemias já houvessem sido identificadas, apenas nos anos 70 foram feitos estudos epidemiológicos detalhados, com coortes claramente definidas de trabalhadores expostos a benzeno, que demonstraram um excesso significativo de leucemias com um risco relativo variando de 3,75 a 8,57 nos vários estudos feitos. Um deles foi realizado pelo National Institute of Ocupational Safety and 
Health (NIOSH), coorte que ficou conhecida como da Pliofilm no estudo de Infante e Rinsky; o segundo foi realizado por Ott e colaboradores, com trabalhadores da Dow Chemical; um terceiro, feito com trabalhadores petroquímicos por DeCoufle, não foi utilizado pela OSHA por não conter informações sobre a exposição, o que motivou também o descarte de outros estudos (Infante e White, 1985).

A longa passagem do limite de 10 ppm para 1 ppm, iniciada nos EUA em 1977, emblematicamente sintetiza este novo momento em que a discussão passa a se concentrar nos novos padrões de contaminação ambiental em ambientes de trabalho, padrões substancialmente menores, que já se encontravam naquele período nos países desenvolvidos e que se mantêm em diminuição até hoje, colocando como questão central: afinal, é seguro expor-se ao benzeno, mesmo em pequenas concentrações?

Até o início da década de 70 os achados de danos provocados por benzeno se relacionavam com níveis de exposição bastante elevados, que resultavam em casuísticas mais numerosas envolvendo principalmente alterações hematotóxicas, muitas delas típicas de intoxicações crônicas, mas que muitas vezes se desenvolviam de forma acelerada devido à intensidade da exposição. Em investigações feitas na década de 1920 foram estimadas exposições de 200 a 1000 ppm por Hogan e Schrader, ou ainda de 90 ppm ou mais por Greenburg (Infante, 2002). Outros estudos estimaram diminuições da exposição de 137 ppm para 32 ppm entre 1940 e 1948, apesar das dificuldades de avaliar com precisão as exposições ocupacionais na época, ainda mais 
acentuadas do que atualmente. Os estudos na Turquia nos anos 60-70 estimavam exposições de 210 a 650 ppm na industria de calçados no período entre metade dos anos 50 e 1969, quando foi proibida a presença de benzeno em solventes no país (Aksoy, 1987; Bartolucci, 1995). Eram, portanto, padrões de exposição quase sempre bastante elevados que foram diminuindo quase como um todo ao longo do tempo, sem que, no entanto, tenham sido identificados patamares de concentrações ambientais em que não se encontrem agravos à saúde.

Assim, no começo dos anos 70 foram publicados pela Universidade da Carolina do Norte (Estados Unidos) uma série de estudos epidemiológicos, feitos por McMichael e colaboradores, demonstrando excesso de leucemias em trabalhadores expostos a baixas concentrações ambientais de benzeno, decorrentes do uso de solventes de borracha que continham de $1 \%$ a $5 \%$ de benzeno nos anos 40 e aproximadamente 0,5\% em 1970. Em 1977, Infante, Risnky e colaboradores publicaram os resultados do primeiro estudo de coorte de trabalhadores expostos especificamente a benzeno, identificando um risco 5 a 10 vezes mais elevado destes trabalhadores desenvolverem leucemia com exposição em níveis correlatos com os vários limites existentes no período de 1940 a 1971, isto é de 10 a 100 ppm. Com base neste estudo e em outros dados da literatura, o Departamento do Trabalho dos Estados Unidos (OSHA) estabeleceu um limite de exposição de 1 ppm. Este limite foi contestado pelas empresas, tendo sido suspenso pela Suprema Corte Americana que estabeleceu que, antes de promulgar qualquer padronização permanente, o 
Secretario do Trabalho precisaria definir os limites em que o local de trabalho não seria seguro, explicitando que significância teriam os riscos presentes e se poderiam ser eliminados ou minorados por mudanças nas práticas. Os danos que seriam considerados significativos não foram estabelecidos pela Suprema Corte, ficando a critério do Departamento de Trabalho definir esses parâmetros. Em 1987, a Suprema Corte aceitou a argumentação levantada pela OSHA para justificar a diminuição do limite que passou a ser então 1 ppm, estendendo, no entanto, a determinação de justificativa quanto à significância do risco a todas as decisões da OSHA (Aksoy, 1987; Infante,2002).

Independente desta demora na decisão americana, as mesmas empresas que questionaram o novo limite passaram a praticá-lo como referência de concentração ambiental já na década de 70 nos Estados Unidos e na Europa. A discussão, no entanto, não se encerrou, pois os inúmeros estudos promovidos pelos defensores dos diversos pontos de vista conflitantes quanto à possível concentração ambiental que permitiria uma exposição sem danos não permitiram chegar a conclusões consensuais. $O$ foco já era, então, principalmente a relação benzeno e câncer, particularmente as leucemias, e, pelos diversos fatores de incerteza que permeiam estas investigações e pela exposição em si, que superou os marcos da discussão ocupacional, a questão é hoje tratada também como uma questão ambiental. Assim, apesar dos muitos avanços, persistem até hoje questões não resolvidas.

A coorte dos trabalhadores da Pliofilm é ainda referência hoje, tendo sido objeto de discussões e estudos diversos com bastante polêmica quanto à 
avaliação da exposição e conseqüente estimativa do risco, e se tornou objeto de diversos trabalhos além daqueles dos investigadores iniciais.

O terceiro período da história do benzeno se fecha então no final dos anos 80, com dois fenômenos bastante distintos que expressam o assincronismo do uso desta substância no contexto de mundialização da economia e da produção industrial já estabelecida então: por um lado a definição nos Estados Unidos, pela Suprema Corte, do Limite de Exposição de 1 ppm proposto em 1977 e aceito por este órgão em 1987, por outro lado a abertura da experiência chinesa com a divulgação e as primeiras publicações internacionais dos estudos da Academia Nacional de Medicina Preventiva Chinesa, relatando a situação de exposição e adoecimento dos trabalhadores expostos a benzeno nas fábricas chinesas (Yin, 1987). Eram situações quase que diametralmente opostas, pois a introdução do uso do benzeno como solvente industrial e na industria de síntese na China ocorrera apenas nos anos 50, à semelhança de tantas nações com processos de industrialização tardios, sendo o benzeno a substância tóxica a que mais trabalhadores chineses estavam expostos. Um levantamento feito entre 1979 e 1981 estimou o número de trabalhadores expostos em 528,729, exposições muito elevadas com taxas de prevalência de intoxicação muito altas e doenças muito graves.

A tendência de priorizar os estudos sobre benzeno e leucemia iniciada nos anos 50 se consolida nos anos 70 e passa a ser a principal questão tratada nos estudos feitos desde então, sendo os principais deles nos Estados Unidos e, posteriormente, na China, onde se desenvolveram os principais estudos 
sobre benzeno no mundo dos anos 80 até a atualidade, com uma coorte de 74 mil trabalhadores seguidos desde os anos 70. Além disso, há inúmeros estudos pontuais, vinculados a essa coorte ou complementares a ela, entre os quais se destaca o artigo publicado por Lan e colaboradores em 2004, identificando a ocorrência de alterações hematológicas em trabalhadores expostos a menos de 1 ppm (Hayes, 2001; Lan, 2004).

\section{O Caso da China nos anos $70-80$}

Em 1994 o Instituto de Medicina Ocupacional da Academia de Medicina Preventiva Chinesa, centro colaborador para Saúde Ocupacional da Organização Mundial da Saúde, lançou uma publicação que compilava boa parte dos estudos sobre toxicidade do benzeno do grupo de pesquisa da China, num trabalho sistemático feito nos 20 anos anteriores. A publicação visava promover comunicação científica entre a China e outras nações e oferecer informações valiosas para estudos posteriores sobre o mecanismo toxicológico do benzeno. Era constituída de diversos estudos experimentais numa primeira seção sobre Toxicologia do Benzeno. Uma segunda seção apresentava estudos epidemiológicos sobre a intoxicação por benzeno na China, sendo que a maior parte destes estudos haviam sido publicados em revistas científicas estrangeiras, alguns de grande notoriedade que entraram na história dos estudos sobre benzeno, constituindo referência e sendo discutidos até hoje. O interesse por eles foi motivado pela riqueza das informações a respeito das exposições e pela magnitude do problema desvelado em conseqüência de uma 
industrialização rápida e sem medidas adequadas de prevenção e proteção dos trabalhadores, como ocorreu em tantos países, inclusive o Brasil, onde encontramos muitas semelhanças com a China, apesar das diferenças de tamanho. Na terceira seção estavam as preocupações com o diagnóstico, a prevenção de riscos e doenças e o estabelecimento de protocolos de acompanhamento da saúde dos trabalhadores, também aqui de forma semelhante à nossa experiência.

O artigo de 1987, destacado aqui, teve divulgação no British Journal of Industrial Medicine e foi um dos primeiros estudos divulgados internacionalmente sobre os riscos do uso do benzeno na China, a partir do qual uma série de outros passaram a ter espaço na literatura científica internacional (Yin et al., 1987). Estes estudos vinham se desenvolvendo há mais de 20 anos e as trocas de experiências com outros países também já ocorriam há algum tempo. Com a repercussão dessa publicação, pela riqueza e volume de dados, em poucos anos a China se tornou a principal referência mundial sobre o assunto, em especial após sua parceria com o Instituto Nacional do Câncer americano (NIC).

O estudo relata a expansão do uso do benzeno na China com o processo de industrialização a partir dos anos 50. Na década de 1950 foram examinados 3.917 trabalhadores, tendo sido diagnosticados 481 casos de intoxicação crônica por benzeno, o que corresponde a uma taxa de prevalência de $10,1 \%$ (reportado na $1^{\underline{a}}$ Conferência Nacional de Saúde e Doenças Ocupacionais na China, em 1960). Em 1970 foram avaliados 33.312 trabalhadores e encontrados 
366 casos de intoxicação por benzeno, com uma prevalência de 1,1\%. Não há referência se houve aumento de uso do benzeno ou ampliação da investigação, mas ao final da década, entre 1979 e 1981, com a finalidade de obter evidências científicas para recomendar medidas protetoras contra a intoxicação por benzeno, foi feita uma investigação em todo o país.

Nesse estudo, os potenciais avaliados eram os trabalhadores expostos a benzeno ou a misturas contendo benzeno, em fábricas em todo o país, e incluíam: pintura, produção de tinta, produção de calçados, síntese de produtos orgânicos, isolamento com verniz, indústrias de impressão, borracha e petróleo. Foram avaliados 508.818 trabalhadores $(96,23 \%)$ de 528.729 trabalhadores expostos. Entre estes 26.319 (4,98\%) eram expostos a benzeno e 502.410 $(95,02 \%)$ a misturas contendo benzeno, usualmente com tolueno e xileno em concentrações variadas. A origem destes produtos era principalmente as refinarias de petróleo. Havia 27.808 fábricas usando benzeno ou suas misturas, e foram obtidos dados de 19.969 dentre elas. Com estas premissas se obteve a concentração de benzeno em 50.255 locais de trabalho. Em 32.486 destes locais $(64,6 \%)$ as medidas foram de menos de 13 ppm. A média geométrica da concentração de benzeno foi de aproximadamente 6 ppm, e o intervalo de $95 \%$ foi $006-844.74 \mathrm{mg} / \mathrm{m}^{3} ; 1,3 \%$ dos locais tinham concentrações de benzeno acima de 330 ppm.

Entre os examinados foram encontrados 2.676 casos de intoxicação por benzeno, ou seja uma taxa de prevalência de 0,51\%. A taxa de prevalência entre os expostos a benzeno era de $0,94 \%$ e entre os expostos a misturas 
contendo benzeno era de $0,44 \%$. A maior parte dos casos de leucopenia foi encontrada nas fábricas onde havia maior exposição. A concentração de benzeno era maior que aproximadamente 8 ppm em $86 \%$ das fábricas. Apenas em algumas fábricas as concentrações eram menores que 3,3 ppm. Embora houvesse um coeficiente positivo, esperado, entre concentrações mais elevadas e maior número de casos, os achados de casos mesmo nas industrias com menor concentração de benzeno apontaram a necessidade de mudança nos padrões de higiene ocupacional utilizados.

Foram encontrados 24 casos de aplasia de medula e 9 leucemias. Dos 24 casos de aplasia, 17 tinham dados completos registrados: eram 7 homens e 10 mulheres entre 18 e 61 anos, expostos por períodos variando entre 3,5 meses e 19 anos, a maioria da industria de calçados e de fábricas de produção de tintas, mas algumas também de fábricas de colas e reparos e outros de empacotamento de pesticidas. As concentrações de benzeno eram quase sempre muito elevadas, entre 33 e 385 ppm. Em uma fábrica de sapatos, entre julho de 1980 e março de 1981, ou seja num período de 8 meses, quando se usou uma mistura de clorobutadieno com benzeno (1/3) como cola na produção de sandálias, quatro casos de aplasia de medula ocorreram, entre 211 trabalhadores. A exposição dos trabalhadores com aplasia foi estimada em 345ppm. A produção foi paralisada, e após a substituição por um solvente sem benzeno não ocorreram outros casos.

Dos nove casos de leucemia, eram seis homens e três mulheres entre 30 e 62 anos que estiveram expostos entre 7 e 25 anos, com exceção de um 
trabalhador exposto por apenas 2 anos. Seis casos foram de Leucemia Mielóide Aguda, um de Leucemia Linfóide Aguda, um de Leucemia Monocítica Aguda e um de Eritroleucemia Aguda. Seis casos foram precedidos de leucopenia ou pancitopenia (Yin et al., 1987)

\subsubsection{O momento atual}

Em 1989, o Instituto Nacional de Ciências de Saúde Ambiental dos Estados Unidos promoveu um Simpósio sobre Metabolismo, Toxicidade e Carcinogenese do Benzeno. O simpósio foi publicado na renomada revista Enviromental Health Perspectives, e um dos organizadores, o Dr. Bernard Goldstein, faz em seu artigo uma avaliação que dá o tom do quarto período, ao comentar que, apesar de ser até possível para um bom toxicologista argumentar sobre algumas razões pelas quais o benzeno deveria ter um limite de exposição para provocar leucemia, não seria realista esperar que estudos epidemiológicos pudessem provar isto, devido à falta de poder do "negativo" neste tipo de estudo, ou à dificuldade dos estudos experimentais com animais, devido ao número enorme de animais que seria necessário, se houvesse ainda um modelo de leucemia aguda utilizável (Goldstein, 1989).

Se a industria acolheu ou não a opinião do Dr. Goldstein à época, não é possível saber. O fato é que os estudos epidemiológicos que vinham sendo desenvolvidos nos Estados Unidos até então não tiveram prosseguimento, mas a discussão quanto à ocorrência de leucemia abaixo de determinadas concentrações ambientais de benzeno se tornou motivo de debate acirrado, 
pois diversos estudos em outros países comprovaram esta correlação, particularmente na China e na Austrália, onde se desenvolviam os principais estudos de coorte em expostos a benzeno nos anos 90. Nestes estudos, aliás, e principalmente na China, a discussão se ampliou e passou a girar em torno das doenças malignas linfohematopoiéticas como um todo (Infante, 2002).

Estes estudos, desenvolvidos nos anos 90, pela Academia Chinesa de Medicina Preventiva em conjunto com o Instituto Nacional do Câncer dos Estados Unidos $(\mathrm{NCl})$, demonstraram uma relação de dose resposta para exposição a benzeno e ocorrência de leucemia, linfoma, síndrome mielodisplásica e aplasia de medula, em exposições abaixo de 10 ppm, observando ainda riscos relativos elevados para leucemia, síndrome mielodisplásica e linfoma não-hodgkin em exposições muito baixas, em torno de 1 ppm (Hayes,1997; Lan, 2006). Novos estudos na China, em 2004, reportaram a ocorrência de efeitos hematotóxicos, identificando queda de todos os tipos de células brancas e plaquetas em exposições abaixo de 1 ppm. Publicados na revista Science, tiveram grande repercussão, por constituírem novo paradigma para a discussão da intoxicação por benzeno (Lan, 2004).

Na Austrália, a coorte prospectiva Health Watch da indústria australiana do petróleo é um estudo epidemiológico de mortalidade por todas as causas, que faz o acompanhamento de todos os trabalhadores ligados a esta indústria, exceto os dirigentes. É financiado pelo Instituto Australiano do Petróleo, e teve início em 1980, na Universidade de Melbourne. Em 1999 foi transferido para a Universidade de Adelaide. Os artigos que relacionam os achados de risco de 
leucemia com exposição a baixas doses de benzeno foram publicados pelos pesquisadores da Universidade de Melbourne, como resultados decorrentes de um estudo de caso-controle aninhado dentro da coorte. Os pesquisadores encontraram uma forte associação entre leucemia e exposição a benzeno, como em outros estudos, no entanto neste estudo a correlação com os níveis de exposição mostrou níveis muito baixos de exposição, menores do que os estudos anteriores reportavam. A principal contestação a estes estudos, tanto na China quanto na Austrália, é a consideração de uma subestimação da exposição.

Enquanto isso, na Itália, os estudos nas duas últimas décadas têm se voltado para outra direção: a preocupação fundamental é com a exposição a baixíssimas concentrações de benzeno, decorrentes da contaminação ambiental proveniente principalmente das emissões veiculares.

A questão central no momento atual em relação ao benzeno é a aproximação destas duas tendências, que se consolidam no século XXI: enquanto diminuem as concentrações de benzeno nos ambientes de trabalho, em ritmos diferentes nas várias regiões do mundo, aumentam as concentrações ambientais de Compostos Orgânicos Voláteis, entre eles o benzeno, decorrentes do aumento das grandes concentrações urbanas, do tráfego de veículos, da industrialização. Este fenômeno também ocorre de forma desigual, pois algumas grandes cidades se transformam em "cidades globais", se desindustrializam, assumem um perfil de cidades de serviços e têm grande volume de investimentos, com modernização de seus sistemas de transportes 
coletivos. Este não parece ser o destino, pelo menos em curto prazo, de cidades como Nova Dehli, Cidade do México, São Paulo ou Bangkok, onde, aliás, a gasolina possui 3,5\% de benzeno.

\subsection{A experiência brasileira}

\subsubsection{0 primeiro período, dos anos 30 aos anos 60 do século $X X$}

As primeiras iniciativas de controle da exposição ao benzeno no Brasil remontam à década de 30 do século passado, quando foram feitas as primeiras legislações restritivas ao trabalho com benzeno no país através da proibição da exposição de mulheres a atividades perigosas e insalubres, em 1932. Dentre as várias atividades relacionadas estava a principal fonte de obtenção de benzeno na época, a destilação de carvão mineral, e os trabalhos com solventes e produtos voláteis e inflamáveis que correspondiam, então, ao principal tipo de utilização desta substância. Posteriormente, em 1939, em Portaria do Ministério do Trabalho, Indústria e Comércio, o benzeno foi relacionado no quadro de atividades industriais consideradas perigosas e insalubres, dando direito ao recebimento de adicional de insalubridade pelos os trabalhadores expostos. Em 1943 foi proibido o trabalho de menores com benzeno e seus homólogos (Novaes, 1992 ; Carvalho et al., 1995; Freitas e Arcuri, 1996; Magrini, 1999).

Há muito pouca informação deste período quanto ao uso do benzeno, à exposição de trabalhadores ou à ocorrência de agravos à saúde. Muito 
possivelmente houve exposição a benzeno já antes dos anos 30 no Brasil, mesmo que em pouca intensidade e em pouca extensão, mas não há registro identificável disto. Não foi escopo deste trabalho esta investigação, que seria possivelmente muito interessante, já que, como vimos na experiência internacional, o benzeno teve vasta utilização na industria têxtil como base para corante, entre outros usos certamente aplicados no Brasil.

Mesmo assim, foi utilizada como linha de corte neste trabalho essa época de acentuada industrialização no país, em que há o surgimento de um corpo jurídico e institucional que modifica o cenário nacional onde vamos encontrar inserido o benzeno. A inclusão do benzeno foi possivelmente muito mais relacionada a esse movimento de mudanças legais do que ao benzeno propriamente dito, pois antes e mesmo depois dos anos 30 é muito pouco visível o uso do benzeno no Brasil. Não se encontram relatos de caso de intoxicação por benzeno ou descrições relacionando o uso do benzeno com os riscos das atividades em que há exposição. É mais provável que sua inserção na legislação, assim como tantas outras legislações, tenha sido fruto de uma importação de informações, não representando uma experiência concreta na realidade nacional. Não é fora de propósito imaginar que as campanhas de Alice Hamilton relatadas neste estudo, feitas justamente nesta década e que tiveram repercussão mundial, tenham ajudado na inserção do benzeno quando da confecção destas legislações no Brasil. A ausência de qualquer outro tipo de informação, no entanto, quanto à sua aplicação prática no país levam a supor 
que pelo menos uma parte destas leis, como tantas outras, não saiu dos papéis.

No compendio de Patologia do Trabalho do Professor René Mendes, o artigo sobre Aspectos Históricos das Patologias do Trabalho, de Mendes e Waissmannn, traz sobre este período, do ponto de vista mais geral, comentário do Professor Cesarino Jr., notório jurista e médico, classificando este momento histórico, que vai de 1931 a 1934, como o "período socialista", "quando numerosas leis trabalhistas mudaram completamente a maneira de se encarar, entre nós, a questão social...". Na periodização proposta pelo Professor Cesarino Jr., seguem o período "social-democrático" (1934-1937) e o período corporativista (1937-1945) propriamente dito, no qual, não por acaso, é concedido o adicional de insalubridade. Ainda nesses anos foi criado o Ministério do Trabalho, e em 1934 foram nomeados os primeiros inspetores médicos do trabalho, tendo prosperado no país as preocupações pela Patologia do Trabalho segundo o modelo francês da Inspeção Médica do Trabalho, e diversas lideranças médicas, entre elas Décio Parreiras e Evio Bustamante fundaram uma "escola" do Ministério do Trabalho (Mendes e Waissmann, 2005).

Não há uma descrição das características desta escola, mas pode-se supor, pelo que se sabe do papel de assessoria que cabia aos médicos na Inspeção do Trabalho na França no século $X X$, e pelo que relata Durval Clemente, engenheiro do Ministério do Trabalho em São Paulo ingressado em 1952, que embora o papel deste órgão fosse de fiscalização para a aplicação 
da legislação sua atuação era principalmente voltada para a orientação: "Fiscalizávamos também. Desde o início tínhamos trabalho externo, verificávamos o cumprimento do capítulo $V$ da Consolidação das Leis do Trabalho (CLT), mas era um combate contra a ignorância - as empresas não cumpriam a lei, por ignorar a lei, era um trabalho mais educativo". (Magrini, 1999)

É nos anos 40 que serão encontradas as primeiras referências técnico científicas ao benzeno, em artigos de revisão da literatura, como relatado por Celina Wakamatsu em sua dissertação de mestrado (Wakamatsu, 1976). Possivelmente não por acaso os primeiros 4 artigos identificados foram escritos entre 1945 e 1946, período que precedeu a inauguração da Companhia Siderúrgica Nacional (CSN) e consequentemente da primeira fábrica de benzeno do Brasil, inaugurada junto com essa siderúrgica. Os trabalhos, publicados em sua maior parte no jornal Imprensa Médica, vinculado ao Ministério do Trabalho, são justamente de autoria de médicos inspetores desse Ministério: G. S. Faria escreve sobre "Benzolismo Profissional" em 1945; D. Parreiras escreve sobre "Doenças profissionais do sangue e de seus órgãos de formação" também em 1945; A.J. P. Menezes escreve sobre "Considerações a respeito das alterações hematológicas nas doenças profissionais" em 1946; dez anos depois, em 1956, Evio Bustamante publicará artigo sobre "Benzolismo Profissional" em 1956 (Wakamatsu, 1976).

Em seu artigo o Dr. Menezes comenta algumas exposições ocupacionais de risco para o sistema hematopoiético, o sistema formador do sangue: 
chumbo, benzeno, radiação ionizante e alguns outros riscos pontuais. Quanto aos riscos relacionados ao chumbo e às radiações ionizantes, além dos aspectos de revisão da literatura científica existente à época, há referências a experiências concretas vividas no Brasil, ainda que relatadas de forma bastante limitada, pelas características do artigo e da publicação. Mas é evidente a intimidade com que é tratada a exposição ao chumbo, contaminação, aliás, que era tradicionalmente investigada e discutida no Brasil desde o século XIX, como relatado por Mendes e Waissmann. As radiações ionizantes são também um assunto próximo para o Dr. Menezes, preocupado com a exposição dos profissionais de saúde que relata ocorrer com frequencia, comentando a necessidade de serem estabelecidas medidas de prevenção de riscos e acompanhamento da saúde destes trabalhadores. No entanto, no que se refere ao benzeno, não há descrição de qualquer experiência ou relato de caso ocorrido no país. Embora haja uma listagem de locais de trabalho e atividades possíveis de se encontrar benzeno, não há referência à sua existência no Brasil, nem ao menos no Rio de Janeiro, mesmo sendo o texto de 1946, ano da inauguração da Companhia Siderurgia Nacional em Volta Redonda, no Estado do Rio de Janeiro, e da primeira fábrica de benzeno derivado da fabricação do coque no Brasil. Também não há no texto qualquer referência à legislação que proibia exposição de mulheres e de menores ao benzeno, nem ao adicional de insalubridade, embora ambas estivessem em vigor na época. O artigo, no entanto, fala com clareza da necessidade de exame hematológico prévio e periódico para observação de alterações hematológicas como um dos principais 
meios diagnósticos da intoxicação crônica por benzeno, conceito que só seria colocado na legislação algumas décadas depois. (Menezes, 1946)

É certo que foi somente depois de 1946 e da inauguração da CSN que começou uma produção industrial um pouco mais significativa de benzeno, ainda assim bastante modesta, que cresceu aos poucos com a ampliação paulatina do parque siderúrgico brasileiro de usinas integradas. Estas últimas são usinas siderúrgicas que tem coquerias, e consequentemente um setor de carboquímicos, vale dizer que produzem substâncias químicas derivadas do carvão, entre as quais, particularmente até o final dos anos 80 , o benzeno, ou benzol, como era mais conhecido o benzeno derivado do carvão mineral produzido pela siderurgia.

Nos anos 50 são inauguradas as primeiras refinarias de petróleo no Brasil, o que dará início à produção de benzeno da industria petroquímica, extraído do refino de petróleo, que porém só passará a ser predominante nos anos 70 quando haverá uma grande implementação na produção de benzeno e mudanças importantes no perfil de sua utilização. Devem ser destacadas nos anos 50, pela sua dimensão e importância, as inaugurações da Refinaria Duque de Caxias (Reduc), no município do mesmo nome no Estado do Rio de Janeiro, e da Refinaria Presidente Bernardes Cubatão (RPBC), no município de Cubatão, no Estado de São Paulo, em 1956. Curiosamente, esta produção industrial de benzeno, que certamente não ocorreu sem risco e sem exposição de trabalhadores - e possivelmente com casos de intoxicação aguda e crônica -, e que cresceu a partir de 1946, afetava uma população provavelmente distinta 
daquela dos anos 30, sendo agora operários do sexo masculino de indústrias com características mais modernas que anunciavam novas transformações que se aprofundariam muito rapidamente nas décadas seguintes.

\section{Principais pontos do primeiro período (1930-1960)}

O mais marcante neste período é o desconhecimento da realidade do ponto de vista da exposição ocupacional ao benzeno no Brasil, com a ausência de registros e relatos de situações de trabalho reais, combinada com uma presença significativa e sistemática de regulamentações trabalhistas visando restringir a exposição ou compensar monetariamente o risco desta exposição, mostrando um descolamento substantivo entre o legal e o real.

\section{Regulamentação}

Neste período foram editadas três regulamentações sobre o benzeno no Brasil, todas pelo Ministério do Trabalho. Duas delas de restrição de exposição, proibindo o trabalho de mulheres e menores, e uma de compensação financeira pelo risco: o adicional de insalubridade. Não há qualquer tipo de registro quanto à aplicação efetiva destas leis.

\section{Exposição}

Não há qualquer fonte de informação quanto às circunstâncias da exposição de trabalhadores neste período, exceto quanto ao fato conhecido de ter tido início a fabricação industrial de benzeno de origem carboquímica (em 1946) e petroquímica (em 1956), e o aumento paulatino desta produção ao longo dos anos. 


\section{Agravos à saúde}

Não há referência quanto á ocorrência de agravos à saúde relacionados com a exposição a benzeno. Embora já houvesse elementos qualificados quanto à maneira como se deveria proceder para fazer este acompanhamento, não há indicação de que isto ocorresse.

\section{Ações}

Não foram encontradas indicações de que ocorressem quaisquer tipos de ações relacionadas ao benzeno alem da feitura das legislações mencionadas e dos artigos referidos.

A síntese deste período pode ser descrita com a idéia de que o benzeno era um problema ainda abstrato entre 1930 e 1960, que não se havia materializado no cotidiano da sociedade brasileira, talvez por não ter ainda uma presença significativa do ponto de vista quantitativo, e não ter se formado uma cultura de prevenção de risco e proteção dos trabalhadores neste período, que poderia ser explicada até pelo fato dos agravos à saúde provocados pelo benzeno permanecerem invisíveis até então, sem o registro de um caso sequer. Há, portanto, muito pouca informação sobre o ocorrido neste período, parecendo haver um descolamento entre a regulamentação, que remonta aos anos 30 , e a capacidade de encontrar agravos à saúde. Embora estes últimos possivelmente cursaram sem ser identificados, apesar do conhecimento existente quanto aos males do benzeno. Talvez por este conhecimento ficar restrito a alguns círculos e os eventuais sucessos ocorrerem de forma dispersa e em número insuficiente para chamarem atenção e formarem massa crítica de 
conhecimento nos serviços, que gerassem capacidade de diagnóstico e intervenção. Ou, o que é pouco provável, não tenham mesmo ocorrido casos.

\subsubsection{O segundo período, de 1960 até 1982: aumento da produção, difusão do uso e aparecimento dos casos de intoxicação por benzeno}

Levantamento feito pela pesquisadora da Fundacentro Química Teresa Novaes com dados da Associação Brasileira da Industria Química (ABIQUIM) ) identificou o aumento da produção e do uso do benzeno no Brasil desde os anos 60. Em 1960 o consumo aparente de benzeno no Brasil foi de 5.720 toneladas, a produção 5.720 toneladas e a importação 20 toneladas. Em 1970 este consumo aparente aumentou em 5 vezes, passando a 25.357 toneladas, com uma produção que aumentou 4 vezes, e uma importação de 3.757 toneladas. Entre 1970 e 1980 o consumo aparente de benzeno passou de 25.357 toneladas para 335.225 toneladas, com uma produção que passou de 21.600 toneladas para 308.528 toneladas, e uma importação, no ano de 1980, de 26.717 toneladas. Houve portanto um aumento do consumo de quase 60 vezes em 20 anos, sendo de aproximadamente 13 vezes nos anos 70 a 80 . Este crescimento da produção de benzeno se sustentava principalmente no benzeno de origem petroquímica em razão do grande aumento de toda a cadeia produtiva do petróleo: extração e refino, petroquímica e química de segunda geração (Novaes, 1992). 
O quadro 2 mostra a evolução do consumo aparente, assim como da produção, importação e exportação de benzeno registradas no Brasil, no período de 1960 a 1990 .

Quadro 2 - Evolução do consumo aparente, da produção, importação e exportação de benzeno no Brasil

\begin{tabular}{|c|c|c|c|c|c|}
\hline Ano & $\begin{array}{l}\text { Consumo } \\
\text { aparente } \\
\text { (Ton) }\end{array}$ & $\begin{array}{l}\text { Produção } \\
\text { (Ton) }\end{array}$ & $\begin{array}{c}\text { Importação } \\
\text { (Ton) }\end{array}$ & $\begin{array}{c}\text { Exportação } \\
\text { (Ton) }\end{array}$ & $\begin{array}{c}\text { Variação de } \\
\text { Preços Médios } \\
\text { (Ton) }\end{array}$ \\
\hline 1960 & 5.720 & 5.720 & 20 & 0 & - \\
\hline 1970 & 25.537 & 21.600 & 3.757 & 0 & - \\
\hline 1980 & 335.225 & 308.528 & 26.717 & 20 & - \\
\hline 1981 & 274.796 & 316.644 & 0 & 41.848 & - \\
\hline 1982 & 349.486 & 357.889 & 0 & 8.289 & - \\
\hline 1983 & 366.733 & 435.769 & 0 & 69.036 & 100 \\
\hline 1984 & 403.980 & 489.969 & 0 & 85.989 & 87 \\
\hline 1985 & 422.285 & 514.870 & 0 & 92.827 & 91 \\
\hline 1986 & 462.268 & 524.095 & 0 & 61.827 & 70 \\
\hline 1987 & 506.023 & 601.657 & 0 & 95.633 & 71 \\
\hline 1988 & 512.816 & 590.152 & 0 & 77.336 & 69 \\
\hline 1989 & 547.746 & 596.368 & 0 & 48.600 & 64 \\
\hline 1990 & $?$ & 605.695 & 0 & 60.425 & $?$ \\
\hline
\end{tabular}

Fontes: Anuário da indústria química brasileira - ABIQUIM - 1987, 1988, 1990, 1991, apud Novaes, 1992.

Não há praticamente informações sobre a exposição a benzeno nos anos 60, e muitos poucos casos de doença relacionados com benzeno foram identificados. Estes poucos são no entanto os primeiros casos relacionados com exposição que são identificados no Brasil e sobre os quais há algum tipo 
de registro. Trata-se de um relato de casos que não é especificamente de caráter ocupacional, mas sim um estudo hematológico com levantamento de 30 casos de Anemias Aplásticas Adquiridas feito por Cillo em 1996, que identificou em dois deles o benzeno como agente etiológico (Wakamatsu 1976; Maluf 2001). Seja como for, no percurso entre o consumo de 5.720 toneladas em 1960 para as 25.357 toneladas em 1970, o cenário foi se modificando de forma bastante significativa. Posteriormente, em 1971, Oliveira relatou 23 casos de Anemias Aplásticas Adquiridas e atribuiu a dois deles o benzeno como agente etiológico (Wakamatsu, 1976; Maluf, 2001)

A partir dos anos 70 encontramos relatos publicados chamando atenção para os riscos dos solventes devido à presença de benzeno e tolueno. Uma pesquisa feita por químicos do laboratório do Serviço Social da Indústria (SESI) identificou, já em 1971, numa amostragem bastante reduzida de 8 produtos, que vários deles continham de fato benzeno e tolueno sem identificação adequada, sendo que um dos produtos tinha $26 \%$ de benzeno em sua composição. Os pesquisadores concluíam pelo perigo do uso industrial, profissional e doméstico desses produtos e pela necessidade de aprofundar os estudos para "identificação de componentes nocivos em partidas diferentes de um determinado produto de um mesmo fabricante", antecipando a gravidade do quadro que seria comprovado posteriormente. Ao mesmo tempo os autores sugeriam medidas que só muito depois se tornariam obrigatórias: análise sistemática dos produtos para verificação de sua composição; indicação da 
composição no rótulo; indicações para o uso; padronização de rotulagens; orientações para o publico sobre os riscos (Andrade e Timossi, 1971).

Após um intervalo de 30 anos sem novas regulamentações, em 1973 é concedida aposentadoria especial de 25 anos aos expostos a benzeno. Ainda nesta década foram produzidos diversos estudos sobre exposição a benzeno, sobre a presença de benzeno em solventes e sobre aplasias de medula relacionadas com exposição a benzeno, algumas com curso fatal em poucos meses de exposição, justamente no ano de 1973. (Andrade e Timossi, 1971; Morrone e Andrade, 1974; Wakamatsu, 1976; Wakamatsu e Fernícola 1980; Novaes, 1992).

Com efeito, na primeira metade da década de 70 ocorreu o óbito de quatro trabalhadoras com aplasia de medula após alguns meses de exposição. O relato dos casos, publicado a partir de atendimento no Serviço de Medicina Industrial do SESI São Paulo de trabalhadoras intoxicadas, foi considerado um marco na literatura médica brasileira pela força da associação causal e pelas repercussões no desenvolvimento posterior de investigações e ações preventivas (Morrone e Andrade, 1974; Novaes, 1992)

Inicialmente foi atendida no Ambulatório de Doenças Ocupacionais do SESI uma trabalhadora de 19 anos exposta a benzeno, que vinha apresentando clínica de alterações hematológicas com manifestações importantes, que foi diagnosticada com quadro de Aplasia de Medula Óssea devido ao benzeno, vindo a falecer pouco depois. Na investigação do caso houve a informação de que outra funcionária da empresa havia falecido dois meses antes e outras 
duas funcionárias estavam internadas em estado grave e também vieram a falecer. Além das quatro mortes, investigações clínicas e laboratoriais em 114 funcionários encontraram sinais compatíveis de intoxicação em 106 trabalhadores, sendo um deles classificado como caso grave que se encontrava em acompanhamento quando o trabalho foi realizado. Trabalhavam na indústria 150 trabalhadores, 110 do sexo feminino e 40 do sexo masculino, sendo a maior parte moças entre 18 e 25 anos de idade. Duas seções chamadas de acabamento foram examinadas com maior atenção por manipularem o produto tóxico. Nelas foram identificados problemas importantes de ventilação e medições de curta duração com bombas drager mostraram, entre outros resultados, concentrações de benzeno de 420 ppm e 210 ppm.

A descrição a seguir é suficiente para explicitar o tipo de exposição que ocorria nesta fábrica: "A atividade desenvolvida pelas trabalhadoras que morreram era de colagem de peças plásticas por imersão em benzeno, que era utilizado como solvente, fornecido em galões de 20 litros transferido para litros e destes para copos e pires que eram colocados nas bancadas de trabalho ao lado das funcionárias. Pequenas peças de borracha eram imersas manualmente nos copos ou pires com benzeno e em seguida ajustadas aos plásticos, ficando firmemente aderentes. Cada hora e meia o conteúdo em solvente de um litro era consumido devendo ser substituído. Para encher novamente o litro as funcionárias usavam o método da sifonagem. Uma das extremidades de um tubo plástico flexível era mergulhada no galão enquanto que à outra extremidade do tubo era aplicada sucção bucal para dar início ao 
escoamento do líquido. Como esta operação provocasse mal estar nas funcionárias, estas se revezavam na função de transferir o benzeno dos galões para os litros. Foram frequentes as ocasiões em que o benzeno dos galões chegava à boca das funcionárias. Como equipamento de proteção individual, utilizavam máscara e gorro visando manter a assepsia necessária ao produto plástico."

Esta descrição trágica e quase inacreditável para os dias de hoje faz também pensar em qual era então a importância das legislações que vinham se acumulando sobre o benzeno há mais de 40 anos, para que ocorressem situações de descontrole deste tipo sem que houvesse praticamente relatos de casos de doenças. Os autores relatam ainda terem sugerido a mudança de metodologia do sistema de sifonamento com utilização de pêra de borracha, e a substituição do benzeno; este foi substituído por tolueno e, ao se verificar que continha $25 \%$ de benzeno, foi feita nova substituição, desta vez por xileno, que não continha benzeno (Morrone e Andrade, 1974). Chama a atenção também que não haja relato de situações semelhantes em atividades correlatas já que, como foi ressaltado, estava em curso uma grande expansão da produção e utilização do benzeno. De qualquer maneira esta foi uma das situações com maior repercussão do ponto de vista da saúde pública e da saúde do trabalhador à época e o estudo realizado mostrou a importância do reconhecimento e registro de casos para a divulgação de situações de risco. (Morrone e Andrade, 1974). 
Em 1976 foram publicados estudos realizados pela Dra. Celina Wakamatsu com trabalhadores do setor calçadista nos municípios de Franca e de São Paulo, expostos ocupacionalmente ao benzeno que estava presente na cola utilizada no processo, à semelhança dos trabalhadores estudados por Aksoy e colaboradores na Turquia nos anos 60 e 70 . O estudo teve início a partir do atendimento, no ambulatório de doenças profissionais da Fundacentro, no final de 1974 , de trabalhadores do setor calçadista que manipulavam colas suspeitas de conterem benzeno e tinham queixas compatíveis com os efeitos do benzeno descritos na literatura (Wakamatsu, 1976).

Na visita feita aos locais de trabalho foram identificadas más condições de ventilação, ambiente fechado, e a medição instantânea mostrou 200 ppm de benzeno. Com base nestes dados foi delineado o estudo com os seguintes objetivos: avaliar a presença de benzeno nas colas; avaliar a exposição dos trabalhadores ao benzeno através de indicador biológico; avaliar os efeitos no sistema hematopoiético e os sintomas e sinais da exposição de curto prazo. Foram entrevistados 151 trabalhadores expostos a benzeno: 82 trabalhadores de Franca, de seis indústrias sendo a menor com 50 funcionários e a maior com 700 funcionários, todos trabalhando 45 horas por semana. As atividades se desenvolviam em série em grandes salões expondo assim todos os trabalhadores e não apenas os que tinham atividades com manipulação específica das colas estudadas. Em São Paulo foram entrevistados 69 trabalhadores, em visita a 50 domicílios de "pespontadores"; foram ainda entrevistados em Franca 23 trabalhadores que não tinham exposição a 
benzeno. Foram realizados exames hematológicos e de fenol urinário nos trabalhadores estudados para investigar efeito e exposição.

Nas visitas aos locais de trabalho nas fábricas em Franca foram identificadas exposições contínuas e generalizadas a vapores de benzeno. Os trabalhadores eram, em sua esmagadora maioria, mulheres jovens, entre 13 e 30 anos, e por isso 89\% deles tinham história de exposição de menos de 5 anos e $45,2 \%$ de menos de 2 anos. Em São Paulo, foram visitados 50 domicílios: em $40 \%$ deles havia um local especial para as atividades, mas em 54\% era aproveitada uma dependência da residência, fazendo com que a exposição se estendesse à família, sendo que muitas vezes havia menores que participavam das atividades laborais alem daqueles que se expunham pela contaminação dos lares.

Foram analisadas neste estudo, em 1975, 31 amostras de cola utilizadas na fabricação de calçados em São Paulo. Dessas amostras, 35,5\% continham de 0,5 a $1 \%$ de benzeno e $35,5 \%$ mais de $1 \%$ de benzeno das quais $9,7 \%$ continham mais de $5 \%$. Os resultados variaram entre $0,00 \%$ a $7,68 \%$. As colas que continham maiores teores de benzeno eram as chamadas "colas-benzina", vulgarmente conhecidas como "cola fraca". Quatro destas amostras foram analisadas simultaneamente no Laboratório da Subdivisão de Higiene Segurança Industrial do SESI (Serviço Social da Industria), São Paulo, também por cromatografia gasosa, e os resultados variaram entre $0 \%$ e $25,5 \%$ de benzeno. 
Os valores de fenol urinário dos expostos foram comparados pela autora com os controles a partir das médias. Os resultados foram interpretados simultaneamente com as características do trabalho das populações analisadas. Em Franca foi caracterizada a exposição dos trabalhadores pela diferença dos valores médios de fenol urinário com a população controle, e pelas características de seu trabalho. Isto não ocorreu com os trabalhadores em São Paulo, que não apresentaram diferença significativa dos valores médios de fenol urinário com os controles, ressalvando a possibilidade de ocorrer exposição indireta de moradores da residência, elevando assim o valor também nos controles.

Nas entrevistas foram freqüentes as respostas positivas às perguntas relativas aos sintomas comuns de intoxicação aguda por benzeno: tontura, sensação de embriaguez, sonolência. Também chamaram atenção da pesquisadora a alta ocorrência de queixas de epistaxes, gengivorragias e as alterações de hemostasia no grupo exposto de São Paulo. Como indicador biológico de efeito, a pesquisadora escolheu os exames hematológicos, antecipando, de forma pioneira no Brasil, uma discussão que permanece até os dias de hoje: que valores de normalidade utilizar para analisar as alterações hematológicas provocadas pelo benzeno? A autora fez a análise por etapas, discutindo cada série especificamente, identificando inicialmente estudos brasileiros com valores da série vermelha, comparando-os com estudos internacionais e com seus achados. Não encontrou diferenças nos critérios e as médias para as contagens de eritrócitos estavam nos limites da normalidade. 
Ao analisar os casos individualmente não encontrou nenhum caso de policitemia, mas identificou muitas pessoas com eritropenia tanto em expostos quanto em controles, atribuindo isto às más condições nutricionais e à alta endemicidade de parasitoses intestinais em nossa população.

Para a hemoglobina e o hematócrito, os estudos nacionais encontravam valores discretamente inferiores aos internacionais, o que também se atribuía à alta prevalência de anemia ferropriva. Não foram encontrados resultados significativos nestes elementos. Tampouco nos reticulócitos foram encontradas alterações que pudessem ser valorizadas. Nas plaquetas houve mais variações entre indivíduos, e a autora refere menor número de indicações sobre valores de normalidade, e aqui mais discussões se apresentarão. Os valores de referência considerados normais foram de 200 a $400.000 / \mathrm{mm}^{3}$, por Jannini e de 150 a $300.000 / \mathrm{mm}^{3}$, por Mangrum. No estudo, 4,2\% dos expostos apresentaram plaquetas abaixo de $120.000 / \mathrm{mm}^{3}$ sendo $1,4 \%$ abaixo de $100.000 / \mathrm{mm}^{3}$, o que foi considerado pela autora como sinal de alerta de início de intoxicação crônica por benzeno, lembrando ainda que a alteração de plaquetas pode ser uma das apresentações mais precoces da intoxicação.

Quanto à série branca, não havia registro de estudos brasileiros de normalidade para nossa população àquela época. Não foram encontradas diferenças significativas a não ser individualmente, em particular o caso de uma trabalhadora com apenas 810 neutrófilos, para a qual foi levantada a hipótese de apresentar possível depressão parcial da medula óssea. Os eosinófilos também não foram valorizados, pela dificuldade de diferenciá-los das 
parasitoses tão comuns em nosso meio. Nas outras séries, inclusive linfócitos, não houve qualquer dado relevante a ser destacado.

A autora concluiu ter caracterizado a exposição ao benzeno na população estudada, pelos resultados do fenol urinário e pelos inquéritos preliminares de higiene do trabalho realizados; que os efeitos da exposição ao benzeno são de difícil avaliação, pela superposição com outras patologias prevalentes em nosso meio, encontrando, ainda assim, "casos de alerta" (Wakamatsu, 1976).

Esta mesma pesquisadora, junto com a toxicologista Dra. Nilda Fernícola, foi responsável por redigir o capitulo sobre benzeno no livro didático sobre Doenças Ocupacionais do Prof. René Mendes, publicado em 1980. Neste capitulo estão vários conceitos com perspectivas bastante protetoras que se consolidaram ao longo do tempo, alguns apenas após muitos anos e muitos debates. Dentre eles se destaca que em razão do benzeno ser leucemogênico e provocar elevadas taxas de aberrações cromossômicas, "estas observações estão levando à revisão dos"limites de tolerância" adotados para o benzeno, dada sua ação leucemogênica, ou seja cancerígena. Como tal nenhuma exposição deveria ser admitida", antecipando a restrição à presença de benzeno em solventes, pois à época não havia nenhuma. As autoras defenderam que a concentração máxima permitida deveria ser de 1\%, o que só ocorreria dois anos depois; também antecipando o que só viria a ser praticado alguns anos depois, as autoras preconizaram o acompanhamento médico dos 
trabalhadores a partir da série histórica de hemogramas, comparado com exame feito antes da exposição (Wakamatsu e Fernícola, 1980).

Até 1965 só existiam no Brasil a Refinaria de Cubatão, produzindo alguns produtos petroquímicos, e projetos controlados pelo capital estrangeiro. Em 1967 foi criada a Petroquisa para coordenar e desenvolver a petroquímica nacional, o que implicou em grande industrialização nesta área. Em 1968 começou a construção da Central de Matérias Primas do Pólo Paulista, que chegou a congregar 18 empresas na América Latina, e em 1973 a Petroquisa assumiu o controle acionário da Petroquímica União. O segundo pólo foi construído na Bahia, na região de Camaçari. Sua construção começou em 1972, e em 1978 o presidente Geisel inaugurou a Central de Matérias Primas: esta, junto com mais 10 empresas e com as 6 que já existiam, totalizaram 17 das 42 empresas com previsão de funcionamento até fins de 1980. Ainda no final dos anos 80 estava em implantação o terceiro pólo petroquímico, este no Rio Grande do Sul, em Triunfo.

No entanto há poucos relatos da situação das empresas desta cadeia produtiva no Brasil. Em 1980, no XVIII Congresso Brasileiro de Prevenção de Acidentes de Trabalho, foi apresentado trabalho sobre prevenção do benzolismo na indústria petroquímica relatando o programa de controle médico desenvolvido na Petroquímica União (PQU), já na época uma das principais produtoras de benzeno no país. Foram selecionados setores da empresa em que a concentração de benzeno era maior e os empregados destes setores foram submetidos a dosagens de fenol urinário e hemogramas de 6 em 6 
meses, sendo estudada a evolução deste exames num período de 3 anos e 6 meses. Foram estabelecidos, pelo serviço da empresa, critérios de classificação para exposição e alteração hematológica. A legislação brasileira foi estabelecer o limite de tolerância de 8 ppm apenas em 1978, segundo os autores, e o valor de referência para o fenol urinário de 50 mg/l é de 1983 Quanto às alterações hematológicas, não havia referência legal de normalidade à época, e os autores, de maneira bem diferente da Prof. Wakamatsu que procurou construir indicadores mais próximos de nossa realidade, utilizaram os critérios de Greenburg para a classificação das alterações encontradas, sendo relatados no trabalho os valores de leucócitos em percentuais e considerados diminuídos os leucócitos abaixo de 5.000/ $\mathrm{mm}^{3}$.

Os dados de fenol urinário de 1976 são bastante expressivos e representam uma exposição importante dos trabalhadores da PQU ao benzeno. Não foram feitos exames de fenol nos trabalhadores do escritório, mas os setores investigados mostraram, naquele ano: no setor de controle de qualidade, fenol urinário entre 30 e 64 mg/l em 45\% dos trabalhadores, e de mais de 64 mg/l em 50 deles; no setor de aromáticos, $10 \%$ dos trabalhadores com fenol urinário entre 30 e 64mg/l, e 40,8 \% com mais de 64mg/l; no setor de transferência e estocagem, 33,3 \% com fenol entre 30 e 64 mg/l, 42, 8 \% com mais de $64 \mathrm{mg} / \mathrm{l}$. Dos 383 trabalhadores considerados expostos que foram examinados, 99 tinham leucócitos abaixo de 5.000 células por $\mathrm{mm}^{3}$; não são reportados outros dados de hemogramas. São referidos, mas não 
apresentados, dados de avaliação ambiental de 1 a 7 ppm, e de curta duração de até 25 ppm por no máximo 5 minutos.

Para os autores, nos anos seguintes houve melhora substantiva na exposição e nos indicadores de efeito na PQU. Seja como for, no ano de 1976 havia exposição muito importante a benzeno e indicação de contaminação substantiva de trabalhadores para a qual há dados e evidências. Como em vários outros estudos do período, as doenças ocupacionais parecem constituir um tabu, pois não se avança em sua investigação mesmo quando há elementos comprovando a exposição e sugerindo a existência de agravo à saúde como, no caso, $25 \%$ de trabalhadores com leucócitos abaixo de $5.000 / \mathrm{mm}^{3}$ em que, mesmo se considerarmos este número elevado, certamente entre eles muitos teriam bem menos que isto, além de possíveis diminuições em outras séries, ou ainda outras alterações (Silva e Correia, 1980).

No final da década de 70 , e no começo da década seguinte, houve uma grande valorização da importância da exposição a benzeno, provocada principalmente pelos estudos que mostravam sua presença em solventes diversos. Estudos realizados pela Fundacentro, órgão de ensino e pesquisa do Ministério do Trabalho, a partir, dentre outros, dos relatos de casos referidos acima, identificaram presença significativa de benzeno em inúmeros produtos comercializados no Brasil, boa parte deles de uso doméstico, vendidos em supermercados e lojas de produtos de limpeza domiciliares, e outros de uso industrial utilizados por trabalhadores em atividades laborais. Estudos anteriores já haviam identificado a presença de benzeno em diversos produtos: 
em colas, por Timossi e Andrade em 1971; em produtos industriais, por Carvalho em 1972; em solventes, no caso referido acima por Morrone e Andrade em 1974, e na cola utilizada na indústria de calçados em São Paulo, por Wakamatsu e Fernicola em 1976, todos referidos por Novaes em 1992.

O estudo da Fundacentro teve caráter amplo, com análise de 74 amostras de produtos adquiridos diretamente no comércio ou coletados em locais de trabalho, em 8 estados do país. Alguns dos produtos analisados chegavam a ter em sua composição mais de $90 \%$ de benzeno (Novaes e Gruenzner, 1981). A investigação apontou para a inviabilidade de tomar medidas baseadas em uma avaliação dos produtos utilizados, uma vez que a variação entre eles era muito grande, inclusive entre produtos com a mesma marca e mesma "especificação", que podiam apresentar composições completamente diferentes, a depender da mistura de solventes que lhe dava base.

A gravidade da situação de exposição desvelada por este estudo gerou uma ação inédita e inovadora: a partir de ampla articulação social, envolvendo o Ministério do Trabalho, o Ministério da Saúde, empresas da indústria do petróleo e o Conselho Nacional do Petróleo, os dois ministérios publicaram em 1982 uma Portaria conjunta (a Portaria Interministerial no.3 de 28/4/1982) proibindo a presença de benzeno em solventes, sendo aceita contaminação de no máximo 1\% desta substância em produtos acabados. Esta Portaria constitui um marco regulatório fundamental na história da prevenção da exposição ao benzeno no nosso país pelo seu caráter interinstitucional, por sua perspectiva 
essencialmente preventiva, pela coragem em intervir proibindo a utilização de benzeno em produtos formulados, pela habilidade na fundamentação técnica e no envolvimento dos setores econômicos relacionados com a produção e utilização de benzeno (Brasil, 1982; Novaes, 1992)

\section{Principais pontos do segundo período (1960-1982)}

Neste período muitas transformações ocorrem e o benzeno entra com força total na vida brasileira. Há um ciclo de rápida ampliação da produção e utilização do benzeno com duas vertentes: a do uso como solvente, que se amplia e se encerra neste período, e a do início da hegemonia da produção petroquímica do benzeno, que se consolidará posteriormente. Aparecem os primeiros casos, inicialmente em estudos hematológicos e posteriormente em investigações ocupacionais. As legislações introduzem mudanças importantes, neste período e posteriormente.

\section{Regulamentação}

Praticamente não há referencia quanto à aplicação da legislação que já existia (restrição à exposição de mulheres e menores), mas evidentemente estas leis não eram cumpridas, pois o principal grupo exposto ao benzeno em atividades que envolviam solventes era composto exatamente por mulheres jovens. Também os menores, como alertava a Prof. Wakamatsu em sua pesquisa, acabavam se expondo ao benzeno, fosse diretamente, por se envolver nas atividades de trabalho como ocorre em tantas circunstâncias em que há o deslocamento de atividades laborais para o interior dos lares, fosse 
indiretamente pela contaminação destes mesmos lares e conseqüente exposição de todos os residentes indistintamente (Morrone e Andrade, 1974; Wakamatsu, 1976). Quanto à introdução do direito à aposentadoria especial por exposição ao benzeno, apesar da coincidência com o ano das 4 mortes por aplasia de medula na cidade de São Paulo, não parece haver qualquer relação direta entres esses dois eventos. Também aqui, como nos anos 30 e 40, a inserção do benzeno na lista de substâncias que davam direito à aposentadoria especial ainda não parece ter ligação com nenhum fato da realidade do país.

Já o estabelecimento do Limite de Tolerância (LT) para o benzeno, dentro da Portaria 3214, no ano de 1978, é uma situação bem distinta. Evidentemente esta não é uma legislação feita especificamente para o benzeno, mas a inserção desta substância na portaria diz muito mais do momento histórico que estava sendo vivido e da lógica que fundamentava aquela portaria, uma tentativa de dar resposta aos problemas que se manifestavam de forma cada vez mais significativa, inclusive em relação ao benzeno, no campo da saúde do trabalhador, sempre com características corporativistas.

A repercussão da implantação do Limite de Tolerância, no entanto, foi bastante localizada naquele momento, sendo visível apenas em algumas atividades restritas, como o trabalho apresentado sobre a Petroquímica União ou o relatório feito pela Fundacentro para levantamento do direito de recebimento de adicional de insalubridade na Companhia Siderúrgica Paulista (Cosipa). Aliás, a questão do adicional de insalubridade, seria a que 
prevaleceria por muitos anos como principal alternativa à prevenção de riscos, sendo a principal conseqüência imediata do estabelecimento do Limite de Tolerância, pois o critério principal para a sua concessão, na maioria dos casos, era o cumprimento ou não deste limite pelas empresas. O LT se tornaria uma referencia central, inclusive pela discussão para sua retirada, que ocorreria no período seguinte. A principal legislação é aquela que encerra este segundo período: a proibição de benzeno em solventes, que definiu a mudança do perfil da exposição a esta substância no país.

\section{Exposição}

Os dados relativos à exposição são bastante dispersos e quase sempre pontuais. Alguns estudos, muito importantes, mostraram a presença de benzeno em solventes. É interessante notar que estes estudos ao longo da década de 70 vão investigando um número cada vez maior de produtos e encontrando um percentual cada vez maior de benzeno nestes produtos. Apenas como ilustração, o primeiro estudo em 1971 examinou oito produtos e encontrou na maior parte deles quantidades relativamente baixas de benzeno e em apenas um deles $26 \%$ de benzeno. No estudo feito em 1981 - 10 anos depois -, que deu base à legislação que proibiu o benzeno em solventes, foram analisados setenta e quatro produtos e foi encontrado benzeno acima de $1 \%$ em vinte e dois deles, sendo que em alguns havia benzeno acima de 90\%. Como houve, na mesma década de 1970 para 1980, um aumento na produção de benzeno de 25 mil toneladas para mais de 300 mil toneladas, pode-se supor 
que houve um grande aumento da utilização de solventes no país, que tinham em sua composição benzeno de forma cada vez mais significativa.

Apesar dos poucos levantamentos existentes nas populações expostas (trabalhadores nas industrias de calçados, em fábrica de artigos plásticos, na indústria petroquímica e química, na siderurgia), é possível identificar uma tendência à utilização de indicadores biológicos de exposição, no caso o fenol urinário, em vez de avaliações ambientais. Estas, quando feitas, têm descrições pobres e muitas vezes foram realizadas utilizando apenas bombas de medição instantânea. Ainda assim, foram evidenciadas concentrações muito elevadas, como era de se esperar pelas descrições qualitativas das condições de trabalho, pelas concentrações de benzeno presentes nos produtos e mesmo pelos valores de fenol urinário encontrados. Na fábrica onde ocorreram as quatro aplasias foram feitas medições instantâneas com achados de 210 a 420 ppm; no estudo do setor de calçados a medição instantânea feita na visita preliminar evidenciou 200 ppm de benzeno. Na PQU, embora não sejam descritos os métodos e o relato seja muito vago, há referência a valores entre 1 e 7 ppm e até 25 ppm em medições de curta duração. Não por acaso estes últimos valores estão dentro do limites permitidos e entram em contradição com os valores de fenol urinário, que sugerem a ocorrência de concentrações ambientais bem maiores.

Até o início dos nos 80 a exposição a benzeno era seguramente difusa em todo o Brasil ocorrendo de forma significativa não apenas nas industrias que o produziam e utilizavam, mas também numa vasta cadeia produtiva em que 
estava presente misturado em solventes. Há diversas evidências de que esta exposição ocorria em muitas situações de trabalho de forma descontrolada, expondo os trabalhadores a risco importante. Apesar da restrição à exposição de mulheres e menores ao benzeno, há evidências que muitas atividades que envolviam exposição a solventes (que como foi comprovado neste período tinham benzeno em sua composição), eram atividades que envolviam justamente mulheres e menores, que não raramente constituíam a maior parte da força de trabalho, e não havia qualquer preocupação com este aspecto singular da questão.

\section{Agravos à saúde}

Apenas neste período começaram a ser identificados os primeiros casos de intoxicação por benzeno no Brasil. A partir de 1966, em menos de sete anos, um número importante de casos graves, aplasias de medula, foram relatados: dois por Cillo em 1996, dois por Oliveira em 1971, quatro por Morrone e Andrade em 1973, que referem ainda haver uma quinta trabalhadora em estado grave sobre a qual não houve mais notícias posteriormente. Na mesma fábrica em que morreram as quatro trabalhadoras foram identificados sinais compatíveis de intoxicação em 106 trabalhadores, mas não há informações sobre acompanhamento posterior destes casos. Depois de 1973 e até meados da década de 80 não há registro de doença por benzeno no Brasil.

No estudo de Wakamatsu em que foram feitas avaliações hematológicas e comparações bastante criteriosas, inclusive antecipando uma preocupação ainda atual com critérios de normalidade, não foram feitos diagnósticos de 
casos. Na sua dissertação os dados estão apresentados em tabelas na forma de médias com valores de máximos e mínimos, portanto, em que pese a dificuldade para identificar o que a autora denominou "casos de alerta" temos uma trabalhadora com 810 neutrófilos com hipótese de depressão de medula; $5,4 \%$ dos trabalhadores com plaquetas abaixo de $120.000 / \mathrm{mm}^{3}$, sendo $1,4 \%$ deles com plaquetas abaixo de 100.000/mm3, valores considerados "sinal de alerta". Apenas é possível identificar que o menor número de plaquetas é de $80.000 / \mathrm{mm}^{3}$, e o menor número de hemácias é 2.600 .000 . Se estes valores foram referentes à mesma trabalhadora, ela então estava possivelmente cursando com uma pancitopenia Não há registro de algum eventual agravamento posterior.

Quanto ao trabalho da PQU, embora identifique uma grande quantidade de trabalhadores com exposição a benzeno e leucócitos abaixo de 5.000/ $\mathrm{mm}^{3}$, os autores não reconhecem a existência de casos de intoxicação por benzeno na empresa. Assim o fato é que os únicos casos de intoxicação por benzeno reconhecidos e publicados no país neste período são os 8 casos de aplasia de medula e os 106 casos compatíveis com intoxicação por benzeno feitos em 1973.

\section{Ações}

As ações iniciais que podem ser identificadas neste período são pesquisas na universidade que produzem duas teses, em 1966 e em 1971, uma de Doutorado, outra de Livre Docência, sobre Anemias Aplásticas Adquiridas, em que aparecem os primeiros 4 casos relacionados com exposição a benzeno 
no Brasil. Ainda em 1971, o primeiro estudo do Laboratório de Toxicologia do Serviço Social da Industria (SESI), sobre a presença de benzeno e tolueno em solventes advertia sobre a toxicidade destas substâncias, chamando a atenção para os riscos decorrentes deste fato e propondo medidas preventivas. Logo depois, em 1973, o Ambulatório de Doenças Profissionais do SESI faria a investigação dos casos de Aplasia de Medula aqui descritos. Naquele mesmo ano, o Ministério do Trabalho concederia aposentadoria especial para os expostos ao benzeno.

Em 1976 é feito o estudo da Professora Wakamatsu, da Faculdade de Saúde Pública, e em 1978 é publicada a Portaria 3214 pelo Ministério do Trabalho. Logo depois desta portaria podem ser encontrados os primeiros trabalhos feitos por empresas, apresentando dados sobre seus achados e suas ações de prevenção da exposição ao benzeno, ainda que de forma inicial e bastante pontual. No começo da década de 80 o mais marcante é o estudo realizado pela Fundacentro sobre a presença de solventes e a legislação do Ministério da Saúde e do Ministério do Trabalho proibindo a presença de benzeno em solventes.

\subsubsection{O terceiro período, de 1982 a 1995: o descontrole da exposição ocupacional ao benzeno no centro de sua cadeia produtiva}

A produção e utilização de benzeno no Brasil continuaram em franca expansão, e permanecerão assim até 1995, embora numa dinâmica diferente, com um crescimento em outro patamar. Até 1991 a produção praticamente 
dobrou e já a partir de 1981 deixou de haver necessidade de importação de benzeno neste período. De 1980 a 1990 a produção brasileira de benzeno passou de 308.528 ton. para 605.695 ton. Este terceiro ciclo, que se estende até 1994, é marcado pela atenção que vai ser dada à exposição ocupacional ao benzeno em parte das empresas centrais da cadeia produtiva que envolve os riscos de exposição a benzeno: petroquímica e química de segunda geração, onde se produz e usa o benzeno como matéria prima para produzir outras substâncias químicas, e indústria siderúrgica, que tem o benzeno como subproduto em seu processo produtivo. Chama a atenção não haver neste período praticamente qualquer discussão sobre a exposição e doença dos trabalhadores da extração, refino, armazenamento e transporte de petróleo.

Em 1978, foi reconhecida parcialmente a agressividade do benzeno, tendo sido listado na Norma Regulamentadora nำ15, que tratava de agentes insalubres, com um Limite de Tolerância de 8 ppm-mpt (partes por milhãomédia ponderada pelo tempo) para a jornada de trabalho vigente na época, de 48 horas por semana. Este limite foi estabelecido a partir da adaptação do valor de LT estabelecido pela ACGIH e que também era adotado na legislação americana da OSHA, que era de 10 ppm para jornadas de 40 horas por semana. Já naquela época a OSHA havia proposto uma redução desse limite de tolerância para 1 ppm, proposta que havia sido suspensa pela Suprema Corte Americana por solicitação das indústrias do país.

Este vai ser o marco legal referencial principal do Ministério do Trabalho, que será utilizado neste estudo, e é em torno dele e de outras regulamentações 
que foram construídas posteriormente que a discussão será feita, a partir dos principais casos que definiram os rumos da prevenção da exposição do benzeno no Brasil entre 1982 e 1995. Foi um período bastante movimentado na sociedade brasileira e na saúde do trabalhador, com grandes transformações, muitas delas decorrentes de processos de intervenção centrados em ações sociais envolvendo trabalhadores, sindicatos, poder público e empresas. Ocorreram movimentos que tiveram grande importância política ou social e que por mecanismos diversos modificaram de maneira significativa a estrutura de prevenção existente no Brasil à época.

No caso do benzeno, as ações que serão discutidas e que constituíram o foco principal neste período ocorreram nos pólos industriais petroquímicos e siderúrgicos que foram se formando nas décadas anteriores, e que em 1982 estavam funcionando em toda sua capacidade. Não por acaso, mas ao contrário, por causa disto, foram ações desencadeadas por sindicatos de ponta, vanguardas políticas de categorias organizadas, ou com fábricas estruturadas, de grande porte, ou importantes do ponto de vista econômico, ou ambas.

\section{O Caso Cosipa}

No bojo do amplo e vigoroso movimento pela redemocratização do país em curso naquele período, em 1982 Franco Montoro havia sido eleito governador de São Paulo, o que deu impulso a diversas ações neste estado, potencializadas pela maior participação dos trabalhadores na vida do país, e pelas inúmeras possibilidades abertas para atuação institucional e de 
articulação entre organismos distintos. A partir dos estudos e ações existentes, vários movimentos foram desencadeados no ano de 1983 em relação ao risco de exposição ao benzeno: pelo governo do estado de São Paulo na Secretaria Estadual de Relações do Trabalho (SERT); na área da saúde através da Universidade e dos serviços públicos de saúde, e pelo Sindicato dos Trabalhadores Metalúrgicos da Baixada Santista (Lianza e Zidam, 2003)

Naquela época, a área de Medicina e Segurança do Trabalho da SERT realizava, através de convênio com o Ministério do Trabalho, a fiscalização das condições de trabalho no estado de São Paulo. Foi criado nessa secretaria o programa de fiscalização do benzeno, que, a partir de um mapa da produção, distribuição, destinação e uso do benzeno no Brasil, identificava situações e fazia propostas para atuação dos órgãos públicos. A poluição ambiental era uma questão muito debatida naquele momento, considerando que a possibilidade de exposição ampliava-se da população trabalhadora para a população em geral. O município de Cubatão, que contava com 23 indústrias produtoras de fertilizantes, aço, compostos químicos e refino de petróleo, era uma das áreas mais contaminadas do país. Concentravam-se naquela região, e lá permanecem até hoje: a Companhia Siderúrgica Paulista (Cosipa), produtora de aço que também produzia e comercializava, como subproduto, o benzeno; a Refinaria Presidente Bernardes-Cubatão (RPBC), a única refinaria de petróleo que produzia benzeno no Brasil; a Companhia Brasileira de Estireno, indústria química que utilizava benzeno como matéria prima; diversos terminais de armazenamento e distribuição de produtos químicos, inclusive benzeno, além 
de empresas transportadoras de produtos químicos, incluindo, para estas atividades, não apenas o município de Cubatão, mas também o porto de Santos e os terminais da ilha Barnabé, localizados em municípios vizinhos.

Na Baixada Santista, no início da década de 80 , estudos mostraram alterações hematológicas na população e em trabalhadores da região (Naoum, 1984). Desde 1979, trabalhadores da Cosipa tiveram identificadas alterações hematológicas quantitativas com redução de leucócitos devido à redução de neutrófilos decorrente de exposição a benzeno (Ruiz, 1993). Em 1981, um levantamento avaliação do direito ao recebimento do adicional de insalubridade elaborado pela Fundacentro, por solicitação da própria Cosipa, mostrou inúmeras situações de risco, tendo sido identificadas situações de total descontrole de exposição a benzeno e outros agentes químicos (Fundacentro, 1981). Em 1983, um estudo feito por um técnico da empresa apontava para a importância da exposição ao benzeno na Cosipa (Pedro, 1983). As investigações de alterações hematológicas em trabalhadores, pelas várias circunstâncias apontadas, foram então intensificadas, e em curto período de tempo algumas centenas de casos de leucopenia foram identificados pelo Centro de Saúde de Cubatão e pelo Sindicato dos Metalúrgicos, com o apoio de serviços de hematologia da região. O Centro de Saúde de Cubatão estabeleceu então uma estratégia baseada na vigilância epidemiológica, definindo diversas patologias decorrentes do trabalho como de notificação compulsória, obrigatoriedade que até então existia apenas para as doenças infectocontagiosas, tradicional campo de atuação da saúde pública. Em 9 de 
dezembro de 1984 morreu, com leucemia, a primeira vítima do benzeno na Cosipa: Antonio Jose Higino (Diesat, 1984; Augusto, 1991).

O número de diagnósticos evoluiu rapidamente, chegando, em 1985, a 929 trabalhadores identificados. O desvelamento desta situação configurou um impasse importante, consubstanciado no estudo feito por consultoria externa contratada pela empresa que produziu o "Relatório de grupo de trabalho: leucopenia" (Cosipa, 1985), que concluiu pela etiologia ocupacional das alterações hematológicas devido à exposição ao gás de coqueria, sem excluir outras fontes de contaminação por benzeno na empresa. Desta situação complexa resultaram discussões e negociações das diversas partes envolvidas, onde as gestões que vinham sendo feitas pela SERT passaram a contar com a participação e condução do Ministério do Trabalho, através da Delegacia Regional do Trabalho no Estado de São Paulo (DRT-SP), já que a onda democratizante havia atingido naquele ano o governo federal, com impacto semelhante àquele ocorrido anteriormente no estados de São Paulo e outros.

A grande aspiração da sociedade naquele período era a criação de mecanismos de discussão e participação, e foi então construída uma alternativa para tratar o impasse existente: a criação de uma comissão interinstitucional, com participação de todos os setores envolvidos trabalhadores, empregadores e poder público -, com o objetivo de discutir três aspectos fundamentais em questão: o acompanhamento clínico-ocupacional dos casos, inclusive no que se referia ao diagnóstico; a necessidade de implementação de mudanças no processo do ponto de vista tecnológico e de 
proteção dos trabalhadores, e as estratégias de avaliação de risco e sua operacionalização.

A comissão funcionou até 1990, tendo interrompido sua atuação no momento de outra mudança política no governo federal. Alguns produtos importantes foram desenvolvidos pelos sub-grupos de trabalho da comissão. Ainda em 1985, o sub-grupo médico elaborou proposta de consenso para a caracterização do quadro de leucopenia, estabelecendo valores de referência para a tomada de decisão quanto à identificação dos casos e à conduta em relação aos trabalhadores, em particular aqueles relacionados como estando "em investigação clínica". Já naquela época se desenhava um modelo de intervenção nos ambientes de trabalho baseado em três eixos: implementação de mudanças tecnológicas e de processo no ambiente de trabalho, investigação da situação de saúde dos expostos com tomada de medidas em relação aos trabalhadores doentes e criação de mecanismos colegiados de participação locais e regionais. O número de trabalhadores diagnosticados por intoxicação por benzeno ultrapassou os 2.000 casos. Após a divisão inicial em três subgrupos, a Comissão passou a desenvolver um trabalho de acompanhamento cotidiano na empresa, que obteve inúmeros resultados envolvendo de forma pioneira diversas áreas da saúde do trabalhador, como a ergonomia por exemplo, apesar de ter ficado com a denominação de "Comissão de Leucopenia da Cosipa". Este trabalho foi interrompido de forma abrupta em 1989, na mudança do governo federal, e ficou suspenso durante o processo de privatização da empresa (Magrini, 1999; Augusto 1991; Augusto, 1999). 
Uma quantidade importante de informações foi produzida em torno deste processo complexo e de grandes proporções, pelas dimensões da empresa e dos problemas existentes. Destacamos como elementos importantes para a caracterização da exposição ao benzeno os relatórios feitos pela Fundacentro em 1980 e pela própria empresa através do Grupo de Trabalho para Estudo da Leucopenia em 1985. Nestes relatórios há várias referências às situações de exposição existentes, sendo a Cosipa certamente a empresa mais documentada do ponto de vista das avaliações ambientais quantitativas neste período. Por todas estas circunstâncias, desenvolveu tecnologia de recursos humanos e equipamentos para fazer as avaliações, com todas as dificuldades existentes quando se fazem avaliações ambientais quantitativas em locais com condições tão adversas como são usinas siderúrgicas, ainda agravadas pelas situações climáticas extremas tais como calor intenso ou inversões térmicas, comuns no Vale de Cubatão onde as condições de dispersão de ar são bastante desfavoráveis.

Certamente uma das maiores polêmicas na saúde do trabalhador está relacionada com o afastamento dos quase 2.000 trabalhadores que atuavam na área da Cosipa na década de 1980. Apesar do estudo feito por especialistas contratados pela empresa ter confirmado a etiologia ocupacional das alterações hematológicas e a difusão da exposição por toda a empresa, ainda havia questionamentos quanto à relação com o benzeno, questionamentos que permanecem hoje apesar das evidências construídas no processo. Entre as evidências mais importantes e consolidadas estão os estudos feitos no 
Hemocentro da Unicamp, sob orientação do Professor Cármino de Souza, pelos Drs. Milton Ruiz e Lia Giraldo Augusto. Apresentamos a seguir alguns resultados desses estudos.

O Dr. Milton Ruiz, hematologista de referência durante muitos anos na Baixada Santista, fez um estudo da medula óssea de 95 pacientes do grupo de trabalhadores da industria siderúrgica de Cubatão, expostos a benzeno e com neutropenia persistente menor de 2.000/dl, com diagnóstico de intoxicação crônica por benzeno. Na avaliação dos casos não havia qualquer patologia aguda ou crônica que pudesse explicar as alterações hematológicas encontradas. Também foi pesquisado o uso de medicamentos mielotóxicos e citotóxicos para o tecido hematopoiético da medula óssea. Os achados foram hipocelularidade global em 74 casos, com ênfase na redução do setor granulocítico em 79 casos; eosinofilia em 64 casos; o setor menos comprometido foi o eritroblástico com 42 casos de hipocelularidade. As alterações morfológicas mais evidentes foram as atipias do setor megacariocítico, com a presença preponderante de micromegacariócitos. Foram identificados dois casos de mielodisplasias. Foi observado ainda aumento de fibras de reticulina em 10 casos. O estudo histológico identificou também outras alterações, como edema intersticial em 20 casos e hemorragia intersticial em 16 casos. No estudo citológico, 65,7\% tinham a relação granulocítica/eritoblástica inferior a três e 51,2\% tinham também esta relação inferior a dois. Na avaliação do sangue periférico, além da neutropenia, foram 
encontrados macrocitose em $18,5 \%$ dos casos, eosinofilia em 27,4\%, monocitopenia em 66,3\% e linfocitopenia em 20,0\% (Ruiz, 1989).

No estudo feito pela Dra. Lia Giraldo Augusto, foram estudadas 57 amostras de medula óssea de 61 pacientes oriundos da construção civil que desempenhavam suas funções na área da Cosipa, e que estavam afastados do trabalho por neutropenia persistente menor de $2.000 / \mathrm{dl}$, tendo realizado biopsia de medula e tendo caracterizada exposição ao benzeno. Das 57 medulas analisadas, 98\% apresentavam-se alteradas. A análise dos tecidos das medulas mostravam aumento do tecido gorduroso em $77 \%$ delas, sendo de moderado a intenso em $76 \%$; focos de necrose em $47 \%$ dos estromas; $28 \%$ com edema intersticial; $21 \%$ com hemorragia intersticial; $14 \%$ com fibrose e $26 \%$ com aumento discreto de fibra de reticulina. No que se refere ao tecido hematopoiético, as alterações mais significativas foram a presença de hipocelularidade global em $89 \%$ dos casos, e de hipocelularidade da série granulocítica em $93 \%$ deles. A relação entre a série granulocítica e eritroblástica (G/E) estava diminuída em $77 \%$ dos casos; a intensidade das alterações hipocelulares foi de moderada a intensa em $77 \%$ deles. Encontrou-se displasia da série granulocítica em $21 \%$ dos casos, diseritropoiese em $24 \%$, atipias de megacarioblástos em 88\%, presença de tecido mielodisplásico trilinear (TMDS) em 14\% e localização anormal de células proliferativas imatura (ALIP) em 7\% (Augusto, 1991; Augusto, 1993)

Os resultados dos estudos feitos na Unicamp comprovaram a gravidade e extensão do problema, contribuindo também com o aprofundamento do 
conhecimento de diversos aspectos relacionados com a intoxicação do benzeno pouco valorizados no Brasil. Nas medulas ósseas desses 152 trabalhadores investigados foi encontrada, em $82 \%$ dos casos, hipoplasia generalizada do tecido hematopoiético, e queda dos precursores granulocíticos em $86 \%$. A série eritróide estava diminuída em $41 \%$ dos casos, e a megacariocítica em $57 \%$ dos casos. $30 \%$ dos pacientes apresentaram atipias celulares, a maioria em séries eritróides. Os eosinófilos estavam aumentados em $27 \%$ dos casos. Um dos casos estava com $9 \%$ de blastos. Anormalidades no estroma foram encontradas em 20\% dos casos. Em trabalho posterior, apresentado em 1994, os achados de agravos à saúde detectados após um seguimento de 7 anos, eram o desenvolvimento de Síndrome Mielodisplásica em quatro pacientes: dois casos preenchiam os critérios $F A B$ para diagnóstico de RAEB, um caso tinha uma medula hiperproliferativa com atipias celulares mas blastos abaixo de $5 \%$, e um paciente apresentou sinais de uma Síndrome Mielodisplásica hipocelular. Um dos pacientes com RAEB desenvolveu Leucemia Mielóide Aguda (Ruiz e col.,1994).

A Comissão Interinstitucional sobre Leucopenia na Cosipa foi reorganizada em fevereiro de 94, já com a empresa privatizada, contando com representantes dos diversos setores: empresa, sindicatos de trabalhadores, Ministérios Públicos estadual e do trabalho, Previdência Social, Secretaria de Saúde e Ministério do Trabalho. A Comissão tinha por objetivo equacionar os problemas decorrentes da exposição ocupacional ao benzeno na empresa com a participação das partes envolvidas. Em vistorias realizadas em 1994 por essa 
Comissão Interinstitucional, com a participação de representantes dessas entidades, foram constatadas inúmeras situações de exposição de trabalhadores e de contaminação ambiental, muitas delas registradas em fotografias, onde é possível ver múltiplos vazamentos e condições de trabalho precárias. Diversos "acidentes operacionais" de grande porte e situações de risco de acidentes graves foram detectadas e relatadas neste período, em que a Comissão Interinstitucional tomava conhecimento da situação da empresa, uma vez que as atividades regulares de inspeção com caráter multidisciplinar e interinstitucional estavam interrompidas desde 1989. Já era notável neste período o esforço dos prepostos da empresa em diminuir a importância das situações de risco e contaminação ambiental encontrada nos locais de trabalho, em especial na coqueria e carboquímicos, mas não apenas nesses setores, evidenciando o que persistiria como política no futuro: uma postura permanente de negação das evidências de risco de exposição e agravos à saúde e uma resistência sistemática às propostas de mudanças (Costa, 1996).

\section{A Fábrica de BHC das Indústrias Químicas Matarazzo}

Alem da experiência central dos trabalhadores intoxicados na Cosipa, outros casos significativos de intoxicação foram identificados neste período. Entre eles, a fábrica de hexaclorocilcohexano $(\mathrm{BHC})$ das Industrias Químicas Matarazzo, que sintetizava BHC para o Ministério da Saúde, e que foi interditada em 1985 pelo Ministério do Trabalho, em razão da contaminação de 34 dos 60 trabalhadores da empresa, com a ocorrência de uma morte por 
Leucemia Mielóide Aguda. A empresa nunca voltou a funcionar e as altas concentrações ambientais de benzeno lá encontradas (acima de 1.000 ppm), assim como o percentual de trabalhadores contaminados, são expressão de uma situação similar àquela registrada na década de 70 em nosso país e, internacionalmente em décadas anteriores, mostrando também as diferenças dos padrões de exposição com os países do primeiro mundo, diferença que permanece até hoje.

O então Diretor da Divisão de Segurança e Medicina do Trabalho (DSMT) da Delegacia Regional do Trabalho em São Paulo (DRT-SP), participou diretamente dessa experiência, relatando-a posteriormente em sua tese de doutorado, que inicia referindo-se à situação de grande movimentação que existia naquela repartição pública na época devido à mudança de governo e regime ocorrido no país e à grande abertura em curso na DRT-SP: "Como aspecto qualitativo daquelas intervenções, verifica-se que aquele experimentar, inicialmente tumultuado, produziu o refinamento da política de abertura, por meio da qualificação da demanda sindical, que era abundante e nem sempre pautada por informações que pudessem levar ao saneamento de ambientes de trabalho de fato agressivos" (Magrini, 1999).

Foi nessas circunstâncias que, em setembro de 1985, surgiu a principal demanda qualificada da história da DSMT: o Sindicato dos Químicos do ABC denunciou que eram precárias as condições de trabalho na fábrica do veneno "BHC" da Matarazzo em São Caetano do Sul, o que viria a deflagrar uma das 
mais significativas intervenções no campo da Segurança e da Saúde do Trabalhador do Brasil.

$\mathrm{O} \mathrm{BHC}$ (hexaclorociclohexano) era ali obtido industrialmente a partir da reação de síntese de outros dois "venenos": o cloro e o benzeno. A este último atribuía-se atenção especial, já que a redução da capacidade da medula óssea em produzir células sangüíneas já era reconhecida como ação tóxica grave decorrente da exposição crônica a seus vapores. Dadas as suas características toxicológicas e com base em pesquisas realizadas em 1981 pela Fundacentro, o uso do benzeno havia sido regulamentado no Brasil, por meio de portaria interministerial, visando reduzir ao máximo e eliminar onde possível seu uso, de maneira ampla, não restrita ao âmbito ocupacional.

A comercialização do BHC já se encontrava proibida no Brasil mas a legislação trabalhista não o mencionava; a Matarazzo possuía licença especial para fornecer o produto apenas para a Superintendência de Campanhas de Saúde Pública (SUCAM), órgão da Secretaria Estadual da Saúde que empregava o BHC no combate ao "barbeiro", transmissor do Mal de Chagas.

Uma primeira inspeção foi empreendida naquela fábrica, em outubro de 1985. Não foi realizada avaliação específica das concentrações de benzeno, porém o levantamento qualitativo do ambiente de trabalho identificou irregularidades grosseiras: poças de benzeno junto aos reatores de síntese, gotejamentos em tubulações, conexões tubulares liberando névoas. Encontrouse BHC espalhado por toda a área, com sua coloração esbranquiçada e seu odor característico, detectado a mais de cem metros. Tal situação era 
decorrente da própria concepção do processo: bateladas de BHC saíam dos reatores de síntese na forma de pasta que, esparramada pelos pavilhões, evaporava e secava até atingir a forma final, de pó. Somavam-se ainda irregularidades nas edificações, como pisos com saliências, depressões e aberturas, escadas em mau estado, sem corrimãos, balcões sem guarda-corpo, que eram agravantes sérios, tendo em vista que o benzeno pode provocar alterações do sistema nervoso central, a ponto de causar fadiga, nervosismo, tontura, vertigens, e intoxicações agudas.

Não havia sistemas de proteção como exaustão eficiente ou enclausuramento dos materiais tóxicos, e o tipo de equipamento de proteção individual fornecido - máscaras respiratórias que não protegiam os olhos e não evitavam a absorção pela pele - era inadequado ao risco.

A empresa não possuía atualizados os exames médicos periódicos dos trabalhadores expostos e nem as medições ambientais, ambos exigidos pela legislação (NR 7 e NR 9). Mas o que mais chamava a atenção era a existência, no andar térreo da fábrica, de um pequeno refeitório, com aquecedor de marmitas, um filtro de água, mesa e bancos para a tomada de refeições, praticamente dentro dos pavilhões onde as pastas de $\mathrm{BHC}$ eram esparramadas para evaporar. Foi então determinada a desativação daquele refeitório.

Além disso, foram impostas naquela primeira visita duas outras determinações: que a empresa eliminasse, em caráter de urgência, as irregularidades grosseiras, e que apresentasse um projeto de adequação de suas instalações. A própria equipe de fiscalização se comprometeu a obter os 
equipamentos para efetuar a avaliação quantitativa do benzeno presente no ar respirado.

Na segunda inspeção, realizada uma semana depois, e acompanhada pessoalmente pelo Delegado Regional do Trabalho, a equipe técnica utilizou três equipamentos: uma bomba de detecção de gás e de vapor, de leitura direta em tubos colorimétricos (tubos de vidro providos de material que muda de cor quando entram em contato com o contaminante que se deseja avaliar), um analisador de vapores orgânicos e um cromatógrafo portátil, que foram emprestados pela COSIPA, que também se encontrava sob fiscalização. Nos diversos postos de trabalho foram medidas concentrações de 50, 200, 300 e até 1.000 ppm, sendo que a legislação brasileira estabelecia 8 ppm como limite de tolerância e a OSHA - Ocupational Safety and Health Administration, do Department of Labor dos EUA já estabelecia novos limites para exposições ao benzeno: 1 ppm para exposição de 8 horas e 5 ppm para exposições até 15 minutos.

Os trabalhadores da empresa foram encaminhados, pelo Sindicato dos Químicos, à Secretaria de Saúde, para serem também avaliados: foram constatados trinta casos de leucopenia (redução do número de glóbulos brancos), além de dois casos revelados pela própria empresa.

O artigo 161 da CLT, e a combinação das Normas Regulamentadoras n.3, n.15 e n.28 permitiam considerar aquela situação como de "grave e iminente risco" ao trabalhador: em 29 de outubro a DSMT finalizou seu laudo 
técnico e apresentou à empresa o "Termo de Interdição" assinado pelo Delegado Regional do Trabalho.

A partir daquele instante, justificar essa medida passou a ser uma necessidade do órgão e da sua equipe técnica, perante não só as lideranças patronais, como toda a sociedade (o que foi feito em ato público no auditório da DRT-SP, para entidades sindicais, patronais, Faculdade de Saúde Pública, Instituto de Química da USP e outras instâncias sociais, do saber e do poder). De fato, apesar de prevista em lei, a interdição ainda era recebida com estranheza e mesmo com incompreensão até por pessoas não afetadas por ela, pois nunca tinha sido praticada no Brasil antes.

O Ministro do Trabalho, visando a rápida desinterdição da empresa, determinou que a Fundacentro se ocupasse de imediato do caso, e a empresa, por sua vez, impetrou um mandado de segurança na $16^{\text {a }}$ Vara da Justiça Federal em São Paulo, alegando abuso de autoridade da DRT, não utilização de equipamentos para avaliação dos riscos e desrespeito ao direito de propriedade. Para "enriquecer" sua argumentação, anexou laudos de um perito engenheiro que atestava jamais terem ocorrido vazamentos de benzeno na fábrica.

O envolvimento da Fundacentro determinou o campo técnico da questão, e a entrada do Poder Judiciário determinou o desenrolar no campo jurídico, com a negativa da liminar pretendida pela Matarazzo e a concessão de dez dias à DRT para que apresentasse a sua defesa. 
Tendo a empresa adotado algumas medidas visando eliminar as emanações de benzeno, autorizou-se, em caráter precário, o funcionamento da fábrica, para que a Fundacentro e a DSMT pudessem avaliar a eficiência de tais medidas. As avaliações realizadas encontraram concentrações abaixo dos limites de tolerância brasileiros, porém o processo de produção encontrava-se semibloqueado, com o benzeno circulando apenas nos reatores de síntese. Considerando que essa não era a condição real de exposição dos trabalhadores, a DSMT se propôs a aguardar o tempo necessário para o restabelecimento completo do processo para então reavaliar, analisar e concluir.

Nesse ínterim, a DRT apresentou sua defesa à Justiça, visando demonstrar que atuara dentro da lei e respaldada pela ciência. A metodologia de avaliação e a fundamentação legal foram apresentadas, bem como documentos referentes ao perito contratado pela empresa, uma vez que seus laudos não encontravam mais aceitação em diversos órgãos do Poder Judiciário, por ser considerado em certidão da $3^{a}$ Junta da Justiça do Trabalho de São Bernardo do Campo como "cidadão que até prova em contrário não reúne idoneidade perante este Juízo".

Em 19 de novembro, a DRT recebeu, por meio de telex, a negativa da Justiça Federal à liminar requerida pela Matarazzo. Aquela comunicação foi de grande importância, não só pelo fato da Justiça ter, inusitadamente, informado seus procedimentos, como também pelo teor do parecer exarado ("não há plausibilidade do fumus boni juris") ratificando a negativa à petição da empresa 
e mais, propondo o encaminhamento do caso ao Ministério Público, "dada a gravidade da matéria".

No dia 11 de dezembro daquele ano, a sentença da $16^{\text {a }}$ Vara anunciava o desfecho do processo aberto contra a DRT, nos seguintes termos: "Não se há de combater o Mal de Chagas à custa da saúde dos empregados que trabalham para a fabricação de tal matéria (BHC)".

No campo técnico porém, as definições ainda não estavam concluídas. A opinião pública acompanhava o caso por meio da imprensa, notadamente o Diário do Grande $\mathrm{ABC}$, que quase que diariamente registrava o andamento da atuação.

No mesmo mês, o Superintendente da Fundacentro foi exonerado de seu cargo e declarou em entrevistas que houve interferências do Ministro do Trabalho pela liberação do setor de BHC da Matarazzo. O Ministro, por sua vez, respondia que o caso Matarazzo era exclusivamente técnico.

As pesquisas prosseguiam, em busca de documentações bibliográficas, e novas inspeções eram realizadas. Constatou-se que o acúmulo de BHC nas dependências da fábrica era muito maior do que havia sido estimado, pois apenas o isômero $\gamma$ ("gama") do hexaclorociclohexano era aceito pela SUCAM, o que correspondia a $40 \%$ do total de BHC produzido. Assim, $60 \%$ da produção do $\mathrm{BHC}$ era considerada resíduo e completava mais de duas mil toneladas despejadas nos galpões da fábrica, contaminando o solo, o lençol freático e a atmosfera. 
Descoberta a importância dos riscos à comunidade, a DSMT realizou contatos com a Companhia de Tecnologia de Saneamento Ambiental (CETESB), dotada de laboratórios especializados e de poder de fiscalização no que se refere à contaminação ambiental. Daqueles contatos, vieram à tona duas informações importantes assumidas pela companhia na "Ficha de Informação sobre produto químico - hexacloreto de benzeno"; a primeira referia-se à neutralização e à disposição final: "dissolver ou misturar o material em um solvente combustível e queimar em um incinerador químico equipado com pós-queimador e lavador de gases; recomenda-se o acompanhamento por um especialista do órgão ambiental". A segunda informação encontrava-se manuscrita: "toxicidade ao homem e animais superiores (vertebrados): carcinogênico, animal positivo".

A CETESB já havia lavrado um auto de infração contra a Matarazzo e estava prestes a lavrar o segundo, conforme sua seqüência rotineira de imposição de multas progressivas, com determinações pelo cessar das atividades, concluindo pela interdição definitiva da fonte poluidora somente após a lavratura do terceiro auto. A tentativa de atuação conjunta CETESB DRT foi encerrada quando aquele órgão revelou que "degraus" poderiam ser ultrapassados somente se houvesse constatação da existência de doentes nas vizinhanças da empresa, e que a ação poluidora da montanha de BHC no lençol freático não era considerada tão grave porque o rio onde deságua, já era poluído. 
Dando continuidade à avaliação do local, foram realizadas novas perícias, desta vez com um cromatógrafo portátil, um photo ionizer e máquinas fotográficas. Em janeiro de 1986 foram constatadas concentrações de 30, 150, 180 e até 200 ppm, e o segundo laudo concluiu que "apesar das modificações efetuadas, permanecem as condições de risco que propiciaram a existência dos casos graves de intoxicação já registrados, condições estas que poderão levar à ocorrência de novos casos", caracterizando assim a permanência da condição de "risco grave e iminente", e mantendo a interdição de outubro de 1985.

A Matarazzo, uma das últimas fábricas de BHC do mundo, optou então pela desativação daquela fábrica, tendo que remanejar os trabalhadores para outras unidades, uma vez que a CLT determina que "durante a paralisação dos serviços, em decorrência da interdição ou embargo, os empregados receberão os salários como se estivessem em efetivo exercício".

No segundo semestre de 1986, um estudo de um médico do trabalho da Fundacentro junto ao Hospital Brigadeiro constatou que o trabalhador da Matarazzo Pedro Mangueira Filho havia morrido com leucemia mielóide aguda decorrente da exposição àqueles agentes químicos. O Ministério Público do Estado de São Paulo, de posse do processo que the havia sido encaminhado pela $16^{a}$ Vara da Justiça Federal, acrescido do atestado comprovando o nexo causal entre as condições de trabalho e a morte do trabalhador, acionou a Vara Criminal do Fórum de São Caetano do Sul, gerando processo civil e processo criminal contra a empresa e seus prepostos. Assim, pela primeira vez na História do Brasil, um diretor de empresa sentou-se no banco de réus para 
responder pela morte de trabalhador por doença do trabalho. A sentença, proferida em 23 de setembro de 1987, absolveu o diretor e condenou a empresa (também, pela primeira vez no Brasil) a indenizar a família da vítima, fazendo com que fossem pagas as despesas de seu funeral e mais: seus salários, desde a morte até o dia em que completaria 65 anos de idade.

Com essas características, o "caso Matarazzo" foi, sem dúvida, o marco que não só definiu, mas garantiu o caráter que a fiscalização poderia assumir, no que se refere a um exercício de poder público dotado de saber técnicocientífico e de política de defesa da vida e da integridade física do trabalhador" (Magrini, 1999).

Certamente o caso Matarazzo foi um marco para diversas questões, dentro e fora da DRT-SP. O Sindicato dos Químicos do ABC realizou um evento e lançou uma revista rememorando os 20 anos da interdição. Mesmo fechada, a empresa continua sendo foco de discussão, pois permanece como área contaminada, com uma polêmica transferência da montanha de resíduos e inúmeras tentativas de utilização da área (até mesmo para parque infantil) que até o momento não teve solução satisfatória, como tantos casos de contaminação ambiental por industrias. Não há informações sobre acompanhamento da saúde do grupo de trabalhadores com diagnóstico de intoxicação por benzeno, apesar da grande repercussão da primeira interdição realizada no país e do primeiro achado de leucemia relacionado com benzeno feito no Brasil. 
Neste caso ainda vale ressaltar a característica melancólica e não casual de tratar-se de grupo industrial dos anos 30-40 ligado à família Matarazzo que já então, nos anos 80, estava em plena decadência.

\section{A Companhia Siderúrgica Nacional ( CSN)}

O município de Volta Redonda está situado ao longo do rio Paraíba do Sul, numa região que, no início do século $\mathrm{XX}$, era de fazendas de café. Originalmente um distrito de Barra Mansa, a vida deste pequeno povoado de 3.000 habitantes começou a se modificar na década de 1940, quando foi implantada a usina siderúrgica Presidente Vargas ou Companhia Siderúrgica Nacional (CSN). A história da implantação da CSN mostra por que existe uma equivalência entre a cidade e a siderúrgica, tema de diversas teses, que a faz uma cidade industrial com a marca de uma "company town" original. As "company towns" são cidades que foram submetidas a uma única empresa que deteve a propriedade do solo e dos equipamentos coletivos, além de um corpo de guardas para garantir a segurança do seu território, e que depois se transformaram em centros urbanos de importância regional; ou ainda cidades ou regiões controladas por uma empresa com dupla perspectiva, de um lado suprir com razoável grau de garantia as necessidades de força de trabalho, através da fixação desta pelo fornecimento de moradia e, por outro lado estender o domínio da empresa ao âmbito privado dos trabalhadores, por meio de vários mecanismos de disciplinamento (Morel, apud Lopes et al., 2004; Gandra apud Reis, 2004). 
A empresa é considerada por instituições especializadas como a Fundação Estadual de Engenhaia do Meio Ambiente (FFEMA), órgão ambiental do estado do Rio de Janeiro, e o Conselho Regional de Engenharia do Rio de Janeiro, uma das maiores poluidoras do estado. Assim pode-se acrescentar à equação CSN - Volta Redonda a questão da poluição, em que a forte relação de dependência econômica existente entre a Companhia e o Município é o fator que mais cria obstáculos para uma discussão mais efetiva dos problemas ambientais, que incorpore o conjunto da sociedade, segundo estudo realizado pela Universidade Federal do Rio de Janeiro. Em pesquisa realizada pela UFRJ entre 1997 e 1999, a poluição aparece como motivo para o desejo de mudar de cidade, e numa lista de coisas que podem estar acontecendo nos bairros, por causa de danos ao meio ambiente, aparece o aumento das doenças respiratórias e o aumento da poluição do ar. As questões ambientais haviam se tornado centrais em 1988, quando uma Ação Civil Pública, instaurada por uma entidade ambiental do município de Macaé, deu margem a um processo judicial de reparação de danos causados pela CSN ao rio Paraíba do Sul, que também banha esse outro municípío. Este processo inaugurou toda uma série de ações em torno da poluição atmosférica e das águas provocada pela CSN. A cidade de Volta Redonda e a CSN foram o epicentro de uma crise política nacional, em 1988, quando a usina, ocupada por trabalhadores em greve, sofreu uma invasão por tropas militares que resultou na morte de três trabalhadores que participavam da ocupação, o que provocou uma grande comoção em todo o 
país. Havia portanto um clima bastante tenso e muito envolvimento de toda a população (Santos, 2003; Lopes et al, 2004; Reis, 2004).

As questões ambientais haviam começado a ser discutidas em 1985, quando a FEEMA começou a fiscalizar a CSN, poupada até então por ser área de segurança nacional, assim como o município de Volta Redonda. Foi na mesma época que a leucopenia surgiu como um tema na cidade. Em 1984, alguns trabalhadores fundaram a Comissão de Leucopênicos dentro do Sindicato dos Metalúrgicos de Volta Redonda. Eram inicialmente eram 50 trabalhadores que haviam sido identificados com alterações hematológicas compatíveis com intoxicação por benzeno. A descoberta desta situação estava relacionada com as mudanças ocorridas na direção do Sindicato, com o ingresso de uma nova diretoria com novas perspectivas de ação e a contratação de assessorias com outras visões, inclusive na área de saúde e trabalho e saúde ambiental. A descoberta da questão do benzeno foi conseqüência da divulgação da experiência da Cosipa, em São Paulo, que teve impacto importante em todo o país (Leite et al, 2004). Rapidamente o número de casos em Volta Redonda aumentou de forma significativa, chegando, em 1993, a 714 trabalhadores, segundo informações do INSS do Rio de Janeiro (Carvalho et al., 1995).

Neste processo de privatização da empresa houve muitas rupturas, com o auge da crise sindical entre 1990 e 1993, com a desfiliação do sindicato da Central Única dos Trabalhadores (CUT) e filiação à Força Sindical, e o governo municipal se opondo à privatização e se aliando ao Programa Estadual de 
Saúde do Trabalhador, que procurava assinar um termo de compromisso em torno dos problemas de saúde do trabalho e saúde ambiental, em particular com referência ao caso da leucopenia. A prefeitura e o governo estadual conseguiram incluir uma cláusula ambiental no edital de privatização da CSN, visando uma compensação do "passivo ambiental", como se em decorrência da mudança do pacto implícito da empresa com a cidade tivesse ocorrido uma "descoberta da poluição, aspecto antes "naturalizado" (Lopes et al, 2004).

Reproduzimos a seguir alguns trechos da dissertação de mestrado da psicóloga Cecília Santos sobre os trabalhadores de Volta Redonda intoxicados por benzeno, intitulada "Quando os elos se partem", que sintetizam o caso da CSN neste período:

"O interesse em pesquisar sobre os mecanismos de defesa psicossociais dos trabalhadores intoxicados por benzeno deve-se à minha inserção como psicóloga no Centro Municipal de Saúde do Trabalhador - CEMUST da Secretaria Municipal de Saúde de Volta Redonda.

Cabe ressaltar que os trabalhadores objeto da presente análise formam um conjunto especial dentre aqueles intoxicados por benzeno, são trabalhadores que permaneceram em média 10 (dez) anos licenciados do trabalho pelo Instituto Nacional de Seguridade Social - INSS, devido ao diagnóstico de benzenismo e, que a partir do ano de 1998 passaram a receber alta médica dos peritos do referido Instituto, e tiveram que retornar compulsoriamente ao trabalho. Portanto, pretendo discorrer sobre as estratégias defensivas que esses trabalhadores construíram ao longo desse período como forma de 
enfrentamento face às repercussões psicosociais provenientes desse afastamento.

Ícone do processo de industrialização no país há aproximadamente 15 anos, o município de Volta Redonda, no estado do Rio de Janeiro, se viu diante de um fenômeno que iria marcar de forma indelével a vida de parte significativa da sua população economicamente ativa: a intoxicação por benzeno, contraída pelos trabalhadores no interior da Companhia Siderúrgica Nacional - CSN. Embora, é claro, outros acidentes já houvessem ocorrido nas dependências da CSN, era a primeira vez que um "acidente" se estendia para fora dos limites geográficos da Companhia e, atingia um número tão grande de trabalhadores, 700 (setecentos) operários, formando uma coletividade de adoecidos, composta pelos colegas de trabalho, familiares, amigos, vizinhos e todos aqueles que de alguma forma estavam/estão ligados a esses trabalhadores.

Para uma melhor compreensão do que significa adoecer no interior da CSN, é preciso considerar a representação social que a Companhia adquire no Município, basta lembrar que Volta Redonda é nacionalmente conhecida como a "Cidade do Aço", leia-se a cidade da CSN, a preposição significando mais que um complemento nominal, um sentimento de pertencimento, de posse.

A Companhia Siderúrgica Nacional foi fundada em abril de 1941. No município de Barra Mansa ficava a Fazenda de Santo Antônio da Volta Redonda, que tinha esse nome em função da volta que o Rio Paraíba do Sul faz na região, mudando sua direção. Construiu-se então não apenas uma siderúrgica, mas uma cidade para atendê-la. Volta Redonda serve então como modelo de 
"Company-town", (...) e surge assim a grande representação dos cidadãos voltarredondenses, em particular dos trabalhadores da CSN, filhos legítimos nascidos do bem sucedido casamento entre a Empresa-mãe e o Estado-pai.

Filhos, que em um determinado momento (década de 80) descobrem-se intoxicados pela grande mãe e posteriormente (década de 90), abandonados pelo benevolente pai - representado pelo Instituto Nacional de Seguridade Social - e, como na mais autêntica trama familiar, desenvolvem sistemas de defesa para lidarem com tal situação. Cabe ressaltar que o logotipo da CSN é uma corrente, logotipo este visível em todos os espaços da cidade, desde os outdoors até os uniformes da rede municipal de ensino, daí o subtítulo desde trabalho, a intoxicação pelo benzeno, representando a ruptura simbólica do elo entre a Companhia e parte significativa da "sua" população, representada pela "comunidade de adoecidos" como descrita anteriormente.

Situação configurada pela perda da identidade psicossocial desses trabalhadores, pois de uma categoria diferenciada, quer concretamente, pelo indefectível uniforme, ou simbolicamente, pelo prestígio social, os operários intoxicados pelo benzeno tornam-se ilegítimos; apátridas dentro de seus domínios.

Cabe ressaltar que pela representação que esses trabalhadores configuram para o município esse é um problema que como já citado afeta a cidade como um todo, uma vez, que os trabalhadores adoecidos são a concretização do risco que povoa o imaginário da população da cidade, tornando o tema benzeno assunto recorrente junto aos habitantes de Volta Redonda. 
Em face do que, esses trabalhadores adoecidos por benzenismo construíram uma estratégia defensiva singular, aglutinando características das ideologias da vergonha e da profissão tal qual descritas por Dejours.

Sobre a ideologia da vergonha Dejours afirma que “... pode-se considerar que a vergonha instituída aqui como sistema constituí uma verdadeira ideologia elaborada coletivamente, uma ideologia defensiva contra uma ansiedade precisa, a de estar doente ou, mais exatamente, de estar num corpo incapacitado... o corpo só pode ser aceito no silêncio"dos órgãos", somente o corpo que trabalha, o corpo produtivo do homem, o corpo trabalhador da mulher são aceitos; tanto mais aceitos quanto menos se tiver necessidade de falar deles ... vê-se que o trabalho atravessa profundamente a vivência da doença: doença-avesso-do-trabalho, a tal ponto que a falta de trabalho torna-se, em si um sinônimo de doença

Quanto à ideologia da profissão, Dejours afirma que esta se destina a evitar discussões quanto ao questionamento de uma dada classe profissional altamente especializada, essa ideologia não é um efeito secundário do trabalho, mas, ... uma verdadeira necessidade para manter um moral feito de orgulho, insolência e agressividade ..."

Nada mais adequado aos trabalhadores intoxicados por benzeno no interior da CSN, pois, ao serem afastados do trabalho, devido ao quadro de benzenismo, um pesado silêncio recaí sobre seus corpos adoecidos, o silêncio da surpresa, do medo, da desinformação e finalmente da vergonha, diante da impossibilidade de trabalhar, de cumprir o destino inexorável dos habitantes 
voltarredondenses, pois como eles mesmos dizem: "Os homens em Volta Redonda são educados para serem trabalhadores da CSN e as mulheres para serem esposas dos trabalhadores da CSN". Destino esse que por mais pesado que possa parecer confere-lhes também um caráter diferenciado, uma verdadeira ideologia da profissão, chegando mesmo em algumas situações a comportarem-se tal qual os pilotos de caça, descritos por Dejours, quer seja no orgulho dos seus uniformes, quer seja na consciência da sua capacitação profissional diferenciada, em especial daqueles que trabalhavam/trabalham na coqueria (setor de produção do coque), e que não por acaso é o setor onde se registrou o maior número de trabalhadores intoxicados." (Santos, 2003)

\section{O caso de Camaçari}

O Pólo Petroquímico de Camaçari foi criado em 1972, inicialmente com 6 empresas, ampliado em 1978 para 18 empresas, e para mais empresas ainda a partir de 1985. O Sindicato dos Trabalhadores daquela época criticava os impactos desta ampliação, feita sem a criação concomitante de um programa contínuo e sistemático de avaliação e controle das condições ambientais e da adoção de medidas de proteção à saúde do trabalhador, que prevenisse os potenciais agravos à saúde decorrentes das condições de trabalho; esta situação era conhecida pelo sindicato através da identificação de doenças ocupacionais nos trabalhadores demitidos, que eram avaliados em seu ambulatório (Sindiquim, 1992) 
Nos anos 90 o Complexo Petroquímico de Camaçari (COPEC) respondia por mais da metade da produção brasileira de petroquímicos, e era considerado o maior em seu gênero na América Latina: constituído por um conglomerado de empresas para produção e processamento de químicos diversos, utilizava basicamente a nafta produzida pela Refinaria Landulfo Alves - Petrobrás. Em 1990, a morte de dois trabalhadores do pólo em decorrência de intoxicação crônica por benzeno - um com aplasia de medula e outro com leucemia mielóide crônica - gerou uma grande comoção e desencadeou processos de discussão que envolveram toda a sociedade baiana e que tiveram repercussão em todo o país.

Os fatos se sucederam de forma muito rápida, revelando o despreparo das empresas e dos órgãos públicos para lidar com a situação, assim como a grande defasagem entre o que necessitava ser feito e o que existia do ponto de vista da prevenção de riscos e da proteção dos trabalhadores. Em julho de 1990 morreu o gerente médico da Nitrocarbono. Suspeitava-se que houvesse relação com exposição a benzeno, o que só foi confirmado publicamente depois, tendo havido polêmica sobre o fato inclusive nos jornais, em que se discutia se o médico havia morrido por "leucopenia" ou não. O diagnóstico do Dr. Armando Sobrinho foi de Aplasia de Medula, o que também foi divulgado pelos jornais somente após algum tempo. Logo após a morte do médico, o Sindicato dos Químicos (Sindquim) solicitou à DRT a fiscalização da empresa, e foi determinado que esta fizesse a avaliação médica dos 442 trabalhadores, o que foi feito em agosto. Em 10 de outubro, o Sindicato solicitou à DRT uma 
tomada de posição, pois a empresa não havia encaminhado o resultado da avaliação. Em 22 de outubro morreu um segundo trabalhador, o operador Antonio Lázaro, em conseqüência de uma Leucemia Mielóide Crônica. Uma semana depois, os trabalhadores fizeram uma greve para garantir determinação, pela DRT, do afastamento de 22 trabalhadores entre 79 suspeitos identificados no levantamento hematológico (Sindiquim, 1992).

Dois dias depois, três Ministros de Estado, Alceni Guerra, José Lutzemberger, e José Goldemberg, respectivamente da Saúde, da Ciência e Tecnologia e do Meio Ambiente, foram ao Pólo de Camaçari discutir o problema da contaminação ambiental e dos trabalhadores, e das mortes ocorridas. Resolveram então que os 40 mil trabalhadores do pólo deveriam ser submetidos a exame hematológico; que a avaliação feita nos trabalhadores da Nitrocarbono deveria ser aprofundada; que era necessário fazer monitoramento ambiental das empresas; que as empresas poluidoras deveriam ser multadas; que deveriam ser aplicados recursos para se fazer acompanhamento hematológico dos trabalhadores. Foram feitas ainda outras promessas de mudanças da legislação e da situação para correção do problema: "Vamos corrigir os problemas daqui como se fez em Cubatão" teria dito o Ministro Goldemberg.

Em novembro a DRT ameaçou interditar a Nitrocarbono, que anunciou então a antecipação, para janeiro, da parada que estava programada para março. Em 14 de novembro foi assinado, em Brasília, o Termo de Compromisso em que a parada ficou estabelecida para o mês de dezembro, e foi criado o 
Programa Integrado de Saúde Ambiental e do Trabalhador (PISAT) para cumprir o que havia sido determinado pelo Ministro da Saúde. Em 6 de dezembro foi iniciada avaliação ambiental, pela Fundacentro, em algumas empresas do Pólo; em 08 de dezembro teve início a parada na Nitrocarbono, como acordado, e em janeiro de 91 foram divulgados os dados da primeira avaliação feita pela DRT, apresentados a seguir.

Quadro 3: Resultados da avaliação das empresas do pólo de Camaçari

\begin{tabular}{|l|c|c|c|}
\hline $\begin{array}{l}\text { Nome da } \\
\text { empresa }\end{array}$ & $\begin{array}{l}\text { № de } \\
\text { trabalhadores } \\
\text { examinados }\end{array}$ & $\begin{array}{l}\text { № de trabalhadores } \\
\text { suspeitos de intoxicação } \\
\text { por benzeno }\end{array}$ & Porcentagem \\
\hline COPENE & 1.660 & 133 & $8,3 \%$ \\
\hline CEMAN & 600 & 122 & $20,3 \%$ \\
\hline CIQUINE & 816 & 85 & $10,4 \%$ \\
\hline NITROCOLOR & 444 & 80 & $4,7 \%$ \\
\hline ESTIRENO & 617 & 29 & $5,2 \%$ \\
\hline NITROCARBONO & 442 & 23 & $10,4 \%$ \\
\hline TOTAL & 4.512 & 472 & \\
\hline
\end{tabular}

Fonte: Sindiquim, 1992

Inúmeras ações foram desencadeadas, porém sem maior articulação entre elas, e principalmente sem o financiamento de um projeto como previsto no PISAT, que jamais veio a ser implementado. Documentos diversos foram 
produzidos, relatando os levantamentos parciais feitos por cada instituição, onde foram apontados problemas importantes que já se suspeitava existirem.

Em seu dossiê, o Sindiquim destaca os seguintes trechos do documento do Centro de Saúde do Trabalhador intitulado "Subsídios para discussão das ações de controle do benzenismo no PPC - Pólo Petroquímico de Camaçari 1992":

"Os estudos realizados comprovam que houve e há contaminação ambiental pelo benzeno com conseqüente exposição ocupacional. Há um quadro epidêmico de agravos relacionados com a exposição ocupacional. Os estudos disponíveis são enfáticos em afirmar que até o final de 1991 as empresas não contavam com programas de higiene industrial ou aqueles desenvolvidos não possuíam metodologia capaz de assegurar validação científica aos resultados e nem efetividade nas ações de controle, uma vez que a avaliação ambiental não tinha como objetivo a eliminação das fontes de contaminação".

"As empresas pesquisadas apresentavam situações onde as concentrações de benzeno superavam os valores do Limite de Tolerância (LT) para 8 horas (8 ppm) e Valor Máximo Permissível (16 ppm) constantes da NR 15”. (Sindiquim, 1992).

Citando o documento da DRT intitulado "Investigação de benzenismo no Complexo petroquímico de Camaçari (BA): Uma proposta de Ação Fiscalizatória, 1991”, o Sindiquim refere que a DRT encontrou, na avaliação de 7.356 prontuários de trabalhadores, 216 suspeitas de benzenismo. 66 funcionários da Copene foram afastados pela DRT por suspeita de Intoxicação 
pro benzeno no primeiro semestre de 1991; diversos dados ambientais desta empresa mostravam níveis acima do LT, alguns até 239 ppm. Na Ciquine, a DRT encontrou até 3.000 ppm. A Central de Manutenção (Ceman) não realizava qualquer tipo de avaliação ambiental; a DRT afastou 83 trabalhadores para investigação. Na Nitroclor havia concentrações ambientais acima de 100 ppm, com 22 casos de suspeita de benzenismo. Na Detem, dados de concentração de 17 ppm, e um trabalhador demitido, com diagnóstico de benzenismo feito pelo sindicato. Na Nitrocarbono, o relatório da Fundacentro apontava 44,1 ppm de benzeno no raqueteamento na Parada. Na Estireno, a os níveis eram de 40,34 ppm de benzeno, e havia 4 trabalhadores afastados. A Polibrasil não fazia avaliação ambiental (Sindiquim, 1992).

Em artigo publicado alguns anos depois, os Auditores Fiscais da DRT apresentaram seus objetivos e resultados: "O presente trabalho constitui-se em um estudo de prevalência, realizado a partir de dados hematimétricos referentes a 7.356 trabalhadores de nove empresas do Complexo Petroquímico de Camaçari, Bahia. Do total de trabalhadores avaliados 216 deles $(2,9 \%)$ apresentaram valores leucocitários abaixo de $4.000 / \mathrm{mm}^{3}$ ou número de neutrófilos abaixo de $2.000 / \mathrm{mm}^{3}$. Para estes últimos, caracterizou-se evidente exposição ocupacional ao benzeno, sendo que todos foram afastados da exposição e encaminhados para investigação hematológica mais aprofundada. O presente estudo permitiu evidenciar o valor do método de vigilância epidemiológica na inspeção trabalhista dos ambientes de trabalho" (Miranda e col., 1997). 
Entre maio de 1991 e julho de 1993, 351 trabalhadores foram afastados ou com diagnóstico de intoxicação, ou para investigação de intoxicação, segundo levantamento feito pelas unidades do Sistema Único de Saúde responsáveis pelo atendimento dos expostos ao benzeno no Pólo (Carvalho, 1995).

\section{A Companhia Siderúrgica Tubarão - CST}

A Companhia Siderúrgica Tubarão (CST), localizada no município de Serra, no litoral do Espírito Santo, a 14 km. de Vitória, é a mais nova das siderúrgicas integradas, inaugurada em 1983. Como boa parte das empresas em todo o mundo, sua composição acionária se modificou bastante ao longo dos últimos anos, no processo de globalização e reestruturação produtiva ainda em curso, mas no período que está sendo relatado a CST era uma empresa trinacional com capitais brasileiro, japonês e italiano, estes dois da Kawasaki Steel e Societá Finanziaria P.Az.Finsider. As primeiras informações obtidas sobre benzeno na CST são do relatório de visita realizada em 1989 por técnicas do Centro Técnico Nacional da Fundacentro, localizado em São Paulo. O objetivo da visita foi atender a uma solicitação da direção do Ministério do Trabalho em Brasília para averiguação de uma denúncia do Sindicato dos Metalúrgicos do Espírito Santo sobre um acidente com fonte radioativa na Coqueria da CST, e sobre vazamentos constantes de benzeno em diversos setores da siderúrgica. Sobre o acidente há referência à apresentação de relatório da empresa, e informações adicionais apresentadas por empregados e 
sindicato, revelando a importância deste risco sempre presente neste tipo de atividade industrial. Quanto ao benzeno, foi constatada na visita a existência de vazamentos de gás de coqueria sendo que a CST, diferentemente das outras siderúrgicas no Brasil, não retirava nenhuma fração do benzeno do gás de coqueria produzido, o que aumentava seu teor no gás de forma significativa (Cardoso e Arcuri, 1989).

Posteriormente, em abril de 1991, foi criado um grupo de trabalho na Delegacia Regional do Trabalho no Espírito Santo (DRT-ES), para investigar os riscos de exposição ao benzeno na CST. Após cinco meses de trabalho o grupo apontava diversos problemas, principalmente a falta de emissão de Comunicações de Acidentes de Trabalho (CAT) por intoxicação por benzeno para trabalhadores que apresentavam alterações hematológicas, e que eram acompanhados às vezes por anos sem terem suas doenças reconhecidas. Foram também comentadas falhas no monitoramento da exposição, havendo referências ainda ao que parecia ser a existência de exposição frequente em locais de trabalho, e à inadequação da estratégia da empresa, baseada principalmente na dosagem do fenol urinário, que não era aplicada aos trabalhadores das "terceiras" expostos. A empresa e as principais contratadas foram notificadas para emitir as CAT, regularizar os serviços especializados e as Comissões Internas de Prevenção de Acidentes (CIPA), e foi formado um grupo de trabalho interinstitucional semelhante àquele da Cosipa, que tinha como prioridade acompanhar termo de compromisso que havia sido firmado entre a CST e o Estado em 1990. Esse termo de compromisso incluía a 
eliminação dos vazamentos de benzeno na coqueria em um prazo de 2 anos e 3 meses; a sistematização das informações dos resultados de acompanhamentos dos casos de leucopenia; a avaliação do monitoramento ambiental; a realização de estudos para o uso de metodologia de avaliação através do ar expirado. Não há informações sistematizadas sobre os resultados deste acompanhamento, porém tudo indica que ocorreram problemas, pois no ano seguinte a DRT notificou a empresa determinando a emissão da Comunicação de Acidente de Trabalho para doze trabalhadores nominados e determinando que a empresa providenciasse informações sobre a série hematológica de outros trinta trabalhadores (Coimbra e col, 1991; Sindimetal, 2005)

\section{A Petroquímica União}

Como foi relatado no Caso Matarazzo, o Sindicato dos Químicos do ABC, em São Paulo, é um dos mais ativos do país, e pioneiro nas lutas em defesa da saúde dos trabalhadores. Faz parte de sua base territorial a Petroquímica União (PQU), que foi a primeira empresa do país a reagir à legislação que estabeleceu o Limite de Tolerância para o benzeno. Ao longo da década de 80 , período classificado neste estudo como o terceiro ciclo do benzeno no Brasil, a PQU continuou a apresentar relatos em revistas temáticas sobre suas ações referentes à prevenção da exposição ao benzeno, atualizando o trabalho apresentado no Congresso Brasileiro de Prevenção de Acidentes de Trabalho de 1980, comentado anteriormente neste estudo (Silva e 
Correa, 1980). Como foi visto, a PQU foi a primeira central petroquímica brasileira, tendo iniciado suas atividades em 1973. Em 1991 o Brasil produziu aproximadamente 800 mil toneladas de benzeno, sendo 170 mil na PQU, que era na época a segunda maior produtora do país, atrás apenas da Copene do Pólo de Camaçari.

No início da década de 90, como repercussão da crise de Camaçari, começou, a partir de uma solicitação do Sindicato dos Químicos do ABC, uma ação conjunta interinstitucional na empresa, envolvendo inicialmente, além do próprio Sindicato, a Secretaria Municipal de Saúde e a Curadoria de Acidentes do Trabalho de Santo André. Esta ação foi relatada posteriormente pelo então Secretário de Saúde do Município de Santo André, que havia participado também do caso Matarazzo (narrado neste estudo) enquanto técnico da Vigilância Epidemiológica do antigo Departamento Regional de Saúde da Secretaria Estadual de Saúde (Galvanese, 1999).

A solicitação era para fiscalização da empresa, face ao grave problema de trabalhadores contaminados por benzeno, do conhecimento pelo Sindicato dos riscos existentes, e da empresa ser de "difícil acesso" segundo dirigente do Sindicato. O coordenador do Programa de Saúde do Trabalhador da Secretaria Municipal de Santo André acrescentou à solicitação o fato de haver uma campanha da Central Única dos Trabalhadores (CUT) denominada "Caça Benzeno", motivada pela crise no pólo de Camaçari, e os trabalhadores do $A B C$ estranhavam que em Camaçari, pólo mais recente, houvesse casos notificados, e no $A B C$ não houvesse nenhum. Na primeira fiscalização, 
realizada em fevereiro de 1991, a empresa admitiu a existência de seis casos de trabalhadores em auxílio-doença acidentário, afastados por benzenismo. Foi ainda apresentada a Relação de Acidentes de Trabalho Sem Perda de Tempo (RAST) do mês de dezembro de 1990, onde foi constatado o registro de oito casos, sendo seis de exposição tóxica a hidrocarbonetos aromáticos, verificadas por valores de fenol urinário acima do Limite de Tolerância Biológica - LTB (superior a $50 \mathrm{mg} / \mathrm{l}$ ). No entanto, foi verificado posteriormente que apenas um trabalhador estava realmente afastado por auxílio doença acidentário. Outros dois trabalhadores, um com leucopenia e outro com leucemia mielóide crônica, permaneciam há mais de 3 anos afastados com auxílio-doença comum. Em abril de 1991 o trabalhador com leucemia faleceu, sua doença sendo reconhecida como doença profissional pelo INSS apenas em setembro (Galvanese, 1999)

A morte do trabalhador teve grande repercussão em Santo André, chegando a ser discutida na Câmara de Vereadores do município. O Sindicato e o Programa de Saúde do Trabalhador (PST) do município colocaram então à disposição dos trabalhadores da empresa a possibilidade de realizar hemograma e dosagem de fenol urinário; assim, entre abril e julho daquele ano, 155 trabalhadores fizeram exames no serviço público municipal. Dos 35 que apresentaram valores abaixo de 5.000 leucócitos ou 2.500 neutrófilos, 33 compareceram posteriormente para reavaliação. Destes, cinco apresentaram valores abaixo de 4.000 leucócitos e 2.000 neutrófilos, e 9 mantiveram valores entre 4.000 e 5.000 leucócitos e 2.000 a 2.500 neutrófilos. Por solicitação do 
PST a empresa emitiu a Comunicação de Acidente de Trabalho (CAT) dos cinco trabalhadores. Posteriormente outros trabalhadores foram afastados, num total de nove casos. Seis dentre eles foram encaminhados para realização de biopsia de medula no Hemocentro da Unicamp, que revelou alterações morfológicas potencialmente relacionadas à intoxicação por benzeno tais como hipocelularidade granulocítica, presença de necrose e hemorragia intersticial, e eosinofilia. Após a consolidação destes diagnósticos, chegou-se à conclusão da possibilidade de haver "grave situação endêmica de benzenismo". Foram feitas diversas tentativas de programação comum entre o município e a empresa para investigação da situação, que foram infrutíferas, tendo ocorrido então uma série de embates entre a Prefeitura e a empresa, em que esta última reconheceu a ocorrência de nove casos durante seus vinte anos de existência, alegando não haver descontrole ambiental. A prefeitura afirmava, no entanto, que a empresa havia notificado espontaneamente apenas um destes casos, sendo os outros resultados da investigação feita pelos órgãos públicos, o que justificava a necessidade de realizar estudo clínico-epidemiológico para avaliação e elucidação da questão. A partir desta proposição o embate entre as partes terminou por inviabilizar a realização do estudo. Em 1993, no entanto, em outro embate e após a interdição da empresa, proposta pelo Ministério Público e determinada pela justiça, devido a uma morte ocorrida em consequencia de uma explosão na ocasião de uma partida, foi estabelecido um processo de negociação entre a empresa e o sindicato, que incluiu as questões relacionadas 
com o benzeno e o acompanhamento dos trabalhadores com alterações hematológicas.

\section{Outros casos de intoxicação por benzeno no Brasil neste período}

Alem destes casos, que tiveram grande repercussão regional ou nacional, também foram registrados casos nos demais pólos petroquímicos. No entanto, houve muito pouca discussão nacional dessas situações, sendo que algumas delas permaneceram silenciadas durante anos, caso do Rio Grande do Sul por exemplo, onde nove trabalhadores do pólo petroquímico foram diagnosticados com intoxicação por benzeno sem que isto tenha tido divulgação nos relatos de levantamento de casos no Brasil, mesmo reconhecendo a dificuldade desses levantamentos (Correa, 2008). Também é surpreendente o pouco conhecimento existente sobre a situação de Minas Gerais, estado onde se localizam 2 siderúrgicas integradas, produtoras de benzeno neste período, uma delas de grande porte. Estas duas siderúrgicas estão situadas em cidades que podem ser classificadas, junto com Volta Redonda, como "company towns". Em Minas Gerais, diferente de todas as outras regiões do país, foi um Núcleo do Ministério da Previdência Social, o Núcleo de Saúde do Trabalhador (NUSAT), que fazia o diagnóstico e acompanhamento da saúde dos trabalhadores, que produziu um relatório com as intoxicações por benzeno nesse estado. Foram registrados 97 casos entre 1989 e 1992, com origem nas industrias siderúrgicas, metalúrgicas e de materiais elétricos (Carvalho et al., 1995). Há ainda em Minas uma refinaria de petróleo do grupo Petrobrás. Este 
grupo, aliás, passa este período sem qualquer registro. Não há qualquer discussão sobre a intoxicação por benzeno nas atividades de extração, armazenamento, refino e transporte de petróleo, embora alguns diagnósticos pontuais tenham sido feitos.

\section{Mudanças no final do ciclo}

Após 1992 a queda no achado de casos, que já vinha ocorrendo, se acentuou ainda mais, passando a haver uma polarização muito grande no movimento social em relação ao processo de privatização que atingia as empresas onde a discussão sobre a intoxicação por benzeno havia tido maior repercussão, ou seja as siderúrgicas e as petroquímicas e químicas de segunda geração. Neste momento, bastante crítico, os sindicatos estavam divididos, e o processo de privatização trazia novos elementos problematizadores, entre eles o passivo social gerado pelo grande contingente de trabalhadores intoxicados por benzeno, afastados do trabalho e sem local seguro para retornar, pois as fábricas continuavam contaminadas. Sem a força política para garantir o reconhecimento dos casos nas empresas, e na disputa em relação à orientação com respeito à privatização ou não, o que prevaleceu neste momento foi a produção de normas que tratavam dos problemas críticos, como os limites de tolerância, para os quais a legislação do Ministério do Trabalho não correspondia ao acúmulo de conhecimento e necessidade que havia naquele momento histórico. Duas normas serão assim produzidas, como reflexo deste acúmulo, uma no estado de São Paulo pela Secretaria Estadual 
de Saúde, em 1992, e outra pelo Ministério da Previdência Social, em 1993. Em 1994, o reconhecimento pelo Ministério do Trabalho do benzeno como substância cancerígena, e a retirada dos limites de tolerância ambiental e biológico determinarão o final deste terceiro ciclo e o início de um novo momento.

\section{Principais pontos do terceiro período}

Vimos, portanto, que nos anos 80 houve uma ruptura do silêncio quase absoluto que havia quanto aos agravos à saúde, com o desvelamento do grave quadro de exposição ao benzeno, e a emergência de várias situações epidêmicas em regiões de pólos siderúrgicos e petroquímicos que possuíam centros e núcleos de saúde do trabalhador que desenvolveram ações efetivas de investigação de casos. A proibição do benzeno em solventes foi bem sucedida, apesar de haver poucos dados a respeito. Ainda em 1982, a mesma pesquisa que fundamentou a proibição foi repetida, e foi verificada uma significativa retração do mercado de produtos formulados em relação ao uso de benzeno, embora persistissem alguns produtos com teores de benzeno elevados. Em 1988, uma nova pesquisa em 30 laboratórios públicos e privados confirmou uma redução significativa da presença de benzeno em produtos no país. Havia fortes evidências desta diminuição, principalmente em produtos distribuídos no mercado consumidor, mas o mesmo não se sabia quanto ao uso de solventes industriais, sendo que há poucos dados porém diversos relatos de achados de solventes industriais com teores de benzeno acima de $1 \%$. Tanto 
para solventes industriais quanto para produtos vendidos aos consumidores não há, até hoje, mecanismos públicos de verificação dos teores de benzeno ou de outras substâncias em sua composição (Novaes, 1992; Carvalho et al., 1995).

Apesar da possibilidade de agravamento de sua situação de saúde nenhum trabalho nacional foi feito para o acompanhamento clínico e epidemiológico destes trabalhadores e boa parte deste grupo não teve seguimento nem mesmo regional.

\section{Regulamentação}

A legislação principal neste período foi o Limite de Tolerância estabelecido em 1978. Seu efeito principal, como relatado, foi dar início a levantamentos de riscos para a concessão do adicional de insalubridade. No caso específico do benzeno temos o registro da Cosipa de 1985, que refere que já em 1981, quando foi feito, pela Fundacentro, o levantamento para definir as áreas merecedoras de recebimento do adicional de insalubridade, a Fundacentro advertiu à empresa haver situação de descontrole de exposição a benzeno, e a Cosipa encaminhou ao INSS trabalhadores com leucopenia para serem afastados, porém este instituto não concordou com o afastamento e os mandou de volta ao trabalho.

Em 1983 foram publicados pelo Ministério do Trabalho os valores de Limite de Tolerância Biológico, no caso o fenol urinário, com valor limite de 50 mg de fenol por litro de urina e $30 \mathrm{mg} / \mathrm{l}$ como valor considerado normal. Não foi explicitada qualquer correlação deste limite com os valores de concentração 
ambiental, o que permitiu a confusão deste indicador com um indicador de efeito e não um indicador de exposição como realmente é (Carvalho et al., 1995).

Em 1984 o Centro de Saúde de Cubatão normatizou a notificação de doenças ocupacionais no pólo industrial. A lista das doenças de notificação incluía o benzeno e estabelecia critérios para a classificação das alterações hematológicas. A normatização foi pioneira e teve grande repercussão, sendo inclusive publicada na íntegra na Revista Brasileira de Saúde Ocupacional, no que praticamente constituiu um número especial dessa publicação; certamente um dos pontos que teve maior impacto foi aquele referente ao benzeno. Em 1985, quando da criação da Comissão Interinstitucional coordenada pela DRTSP, o subgrupo de saúde, que tinha representantes dos trabalhadores, da empresa e dos órgãos públicos, fez uma proposta para o diagnóstico da intoxicação por benzeno que tinha como base aqueles critérios apresentados na normatização do Centro de Saúde de Cubatão. Os mesmos critérios, adotados por consenso e que passaram a ser aplicados, foram utilizados posteriormente pela Secretaria de Saúde do Estado de São Paulo, ao incluir as alterações hematológicas por exposição ao benzeno no Sistema de Vigilância Epidemiológica de Doenças Ocupacionais, em 1986. A circular 297/86, da Secretaria Regional de Medicina Social de São Paulo, do INAMPS, estabeleceu para o município de Cubatão o documento "Critérios para caracterização de leucopenia", que mantinha os mesmos princípios dos documentos anteriores e que cumpriu um papel fundamental na disputa com os órgãos previdenciários, 
que sempre mantiveram uma postura resistente ao reconhecimento das doenças e dos direitos dos trabalhadores. Em 1987 foi feita a circular 03/87, estendendo para todo o Estado de São Paulo os critérios da circular 297/86, e estabelecendo os "Procedimentos Médico-Periciais e de Reabilitação Profissional para os Segurados Portadores de Leucopenia". Este protocolo foi adotado provisoriamente em 1987 pela Secretaria Regional de Medicina Social do INAMPS do Estado do Rio de Janeiro. Em 1991, no Estado da Bahia, o "Protocolo de Intenções para controle do Benzenismo e outras Doenças Hematológicas Ocupacionais do Pólo Petroquímico de Camaçari” criou procedimentos a partir do protocolo de São Paulo, em articulação conjunta de universidades, sindicatos, fiscalização, saúde, Conselho Regional de Medicina e Sociedade Bahiana de Hematologia. No Rio Grande do Sul, também em 1991, foi criado o Comitê Estadual do Benzeno, com o propósito de padronizar critérios hematológicos. Em Santo André, em setembro de 1992, um decreto municipal determinou estabeleceu para a Secretaria de Saúde a atribuição de realizar estudo clínico-epidemiológio sobre benzenismo nos trabalhadores da Petroquímica União (Carvalho et al., 1995).

Ainda em 1992, o Centro de Vigilância Sanitária da Secretaria Estadual de Saúde de São Paulo publicou Norma Técnica referente ao Diagnóstico da Intoxicação e Controle da Exposição Ocupacional ao Benzeno. Esta Norma foi produzida de forma tripartite, com a participação de representantes de diversos órgãos públicos, empresas e sindicatos de trabalhadores. O seu principal ponto foi o reconhecimento do benzeno como substância cancerígena, estabelecendo 
que para a prevenção de agravos à saúde nenhuma exposição ou contato deveria ser permitido, e remetendo a questão da exposição para o controle ambiental, com os mesmo critérios determinados pelo Anexo 13 da NR15 da Portaria 3214 do Ministério do Trabalho que regulamenta o trabalho com substâncias cancerígenas. A norma estabeleceu também um programa de prevenção das exposições a ser implementado pelas empresas, que valorizava os procedimentos de avaliação ambiental qualitativos, e estabelecia para a quantificação da contaminação ambiental um papel preventivo, não se limitando à comparação com o limite de tolerância para pagamento do adicional de insalubridade.

A Norma Técnica de São Paulo constituiu um novo parâmetro técnico e serviu como base para a revisão da Norma Técnica de Benzenismo da Previdência Social de 1991, que reproduzia os critérios da Circular do INAMPS de 1987. Em 1993, o Ministério da Previdência Social criou um grupo revisor composto por representantes dos Ministérios da Saúde, do Trabalho e da Previdência, que elaboraram “Norma Técnica sobre Intoxicação por Benzeno”, publicada no mesmo ano. Esta norma reproduzia basicamente os conceitos da norma de São Paulo, incluindo os itens referentes ao diagnóstico médico e às condutas previdenciárias praticamente na íntegra, o que foi muito importante particularmente quanto às questões previdenciárias. No entanto, apesar da importância destas normas, por seu valor técnico e sua importância histórica e política, não há registro quanto à sua aplicação. É certo que o momento era muito conturbado, com mudanças em todos os níveis de governo - algumas 
delas registradas aqui -, e na conjuntura político-institucional, inclusive em relação à organização jurídica das empresas focos da nossa casuística, ou seja as siderurgias, petroquímicas e químicas de segunda geração, que estavam em processo de privatização ou mesmo já privatizadas. Pouco menos de um ano depois, o Ministério do Trabalho publicou a Portaria 3/94 reconhecendo o benzeno como substância cancerígena, fato que encerra este terceiro período.

\section{Exposição}

Houve mudanças importantes no perfil de exposição neste terceiro período, determinadas principalmente pela proibição da presença de benzeno em solventes. No entanto, não foi possível descartar a ocorrência de exposição nos setores industriais em que havia utilização de solventes, principalmente nos primeiros anos após o estabelecimento da proibição, já que não foram feitos programas de controle de solventes para verificação de sua composição. De qualquer maneira, o principal foco de exposição em discussão neste período passou a ser o trabalhador siderúrgico. E é da Cosipa que se tem o maior número de dados e informações sobre exposição, seja pelo levantamento feito pela Fundacentro em 1980, seja pelos dados das avaliações ambientais quantitativas realizadas pela própria empresa, que constituem certamente o principal banco de dados de concentrações ambientais de benzeno na indústria siderúrgica - e provavelmente de qualquer tipo de atividade industrial - neste período no Brasil. Há, no entanto, muitas dificuldades metodológicas que dificultam uma apreciação melhor das informações que poderiam ser extraídas destes dados. As concentrações ambientais são elevadas e distribuídas por 
todos os ambientes da empresa, não se restringindo aos setores de coqueria e carboquímicos.

Nas outras siderúrgicas onde foram identificados problemas de intoxicação de trabalhadores não há relatos de dados quantitativos ambientais. Pode-se supor que a prática da utilização do fenol urinário como principal instrumento indicador de exposição fosse generalizada nas siderurgias e demais industrias, sendo pontual a prática de realizar avaliações ambientais quantitativas. Há muito poucos dados quantitativos recuperáveis nos estudos e relatórios publicados, e os que existem não referem metodologias. Ainda assim, as concentrações que foram medidas entre 1980 e 1985, quando há maior número de dados, são muito elevadas. Nos anos seguintes estes números caem, e há relatos de melhora nos ambientes, que no entanto não são suficientes para que se conclua que tenha deixado de haver exposição em níveis importantes. Ao final deste período são inúmeras as criticas ao uso do fenol urinário, na forma com estava sendo utilizado, e à sua adequação às concentrações que estariam prevalecendo naquele momento, aparentemente bem menores nos idos de 1994 do que haviam sido em 1982 nestas empresas.

\section{Agravos à saúde}

Este é o aspecto mais marcante deste período: o grande número de casos de intoxicação por benzeno que foram diagnosticados a partir do desenvolvimento de atividades de saúde pública no campo da saúde do trabalhador. Em contraposição ao escasso número de casos encontrado no período anterior - 8 casos de aplasia de medula e 107 casos possíveis sem 
confirmação -, neste terceiro período foram diagnosticados milhares de casos de intoxicação por benzeno.

Certamente muitas coisas foram importantes para possibilitar este grande numero de diagnósticos, mas do ponto de vista técnico foram decisivas as normatizações criadas, que não existiam até então para nenhuma doença ocupacional; o início da caracterização das alterações hematológicas e o aperfeiçoamento dos critérios, ao longo do tempo, permitiram uma qualificação do grupo técnico responsável e uma homogeneização de sua atuação, principalmente do setor público, o que garantiu mais eficiência, segurança e articulação sobre este ponto tão crítico, polêmico e usualmente tão contestado pelas empresas. A ação sinérgica dos sindicatos também potencializou a unificação dos órgãos públicos, superação sua fragmentação.

\section{Ações}

O aspecto mais importante das ações deste período foi seu caráter acentuadamente interinstitucional, possivelmente dinamizado pela atuação dos sindicatos. Também foi marcante neste período o fato da maior parte das instituições participantes estarem há muito pouco tempo desenvolvendo atividades na área de saúde do trabalhador. Esta área, como foi visto aqui, teve seu momento de grande desenvolvimento na década de 1980, pois até então praticamente não havia atividades neste campo, salvo ações muito pontuais e em boa parte de caráter "orientador". Houve naturalmente muito conflito e muitas dificuldades nas definições de papéis, mas foi um processo muito dinâmico em que houve uma evolução muito rápida e um grande aprendizado 
para todos - sindicatos, empresas e órgãos públicos - em várias dimensões, técnica, cultural, política, de negociação, entre outras.

Três aspectos das ações tiveram grande desenvolvimento na experiência relacionada ao benzeno neste período. Um deles foi a intervenção nos locais de trabalho: havia muito pouca experiência até então nesse tipo de atividade, e neste período essas intervenções se tornaram quase corriqueiras, muitas delas foram bastante qualificadas e tiveram grande impacto, provocando modificações importantes nos ambientes de trabalho e na cultura de prevenção e proteção da saúde do trabalhador. Outro aspecto foi a normatização: não existiam critérios para se fazer diagnósticos de doenças ocupacionais até a primeira iniciativa do Centro de Saúde Cubatão, que determinou a notificação de alterações hematológicas em expostos ao benzeno, estabelecendo o primeiro critério para se fazer o diagnóstico da intoxicação por benzeno, que vem sendo aperfeiçoado ao longo dos anos. O terceiro aspecto foi a interinstitucionalidade: boa parte das ações relacionadas com a prevenção da exposição ao benzeno neste período teve participação de diversas instituições e contou com a presença dos sindicatos de trabalhadores como elemento dinamizador e aglutinador dos órgãos públicos.

Um quarto aspecto também bastante relevante é a negociação, mais fácil de visualizar na década de 1980, desaparecendo na siderurgia nos anos 90 e retornando só após a portaria 3/94, no quarto período. De qualquer maneira, este elemento é marcante na experiência da Cosipa, e serviu como um modelo 
para São Paulo, embora haja diferenças acentuadas entre petroquímicas e siderúrgicas.

Finalmente, como já apontado anteriormente, é muito relevante a ausência de relatos de ações positivas ou negativas do setor de petróleo e da siderurgia mineira neste período.

\subsubsection{Novos parâmetros para a prevenção da exposição a benzeno: o acordo e a legislação do benzeno de 1995}

Em 1993 o Ministério do Trabalho e Emprego (MTE) constituiu um grupo multidisciplinar e interinstitucional para fazer o diagnóstico da situação de exposição ao benzeno no Brasil, com a finalidade de subsidiar tecnicamente a revisão da legislação trabalhista a este respeito. Com base nas constatações e propostas do estudo, o MTE publicou em 10/03/94 a Portaria n.3, enquadrando o benzeno na categoria das substâncias cancerígenas, retirando da tabela de limites de tolerância aquele relativo ao benzeno, bem como os parâmetros biológicos utilizados - o limite de tolerância era de 8 ppm e o indicador era o fenol urinário, com valor normal e Limite de Tolerância Biológico (LTB) correspondentes -, e passando a não reconhecer limite seguro para exposição a esta substância. A regulamentação desta Portaria ocorreu após 18 meses de intensa discussão, com grande mobilização dos setores interessados e a formação de um grupo tripartite com representantes do poder público, dos trabalhadores e das empresas, grupo que elaborou uma proposta de Acordo e de Legislação, que foi aceita pelas partes, ratificada pelo governo e publicada 
através do Anexo 13-A da Norma Regulamentadora 15 da Legislação de Saúde e Segurança no Trabalho, que compõe a legislação trabalhista brasileira. Foram também formuladas e publicadas duas Instruções Normativas (IN) que complementam o Anexo 13-A, a IN01, que trata da avaliação ambiental, e a IN 02, que trata da vigilância em saúde.

Os pontos importantes do acordo e da legislação, como forma de restringir a exposição, o uso e a circulação do benzeno, são:

- a proibição do uso do benzeno, admitindo como exceções as empresas que o produzem ou que o utilizam em sínteses químicas, as siderúrgicas e os laboratórios em situações onde ele não possa ser substituído;

- a obrigatoriedade de cadastramento dessas empresas;

- o estabelecimento do conceito de Valor de Referência Tecnológico (VRT), que permitiu assumir uma postura de precaução em que não existe exposição segura para o benzeno, superando o conceito de Limites de Tolerância, inadequado para substâncias carcinogênicas como o benzeno, conforme reconhecido pela legislação alemã na qual conceito se baseou. 0 VRT não é um limite de exposição, não exclui risco à saúde e deve ser considerado como referência para os programas de melhoria contínua, seu cumprimento sendo obrigatório.

- a criação do Programa de Prevenção da Exposição Ocupacional ao Benzeno, principal instrumento técnico de prevenção, que inclui as instruções normativas de monitoramento ambiental e vigilância da saúde, que deve 
expressar o consolidado das ações realizadas pela empresa para prevenir a contaminação dos trabalhadores.

- a definição dos Grupos de Trabalhadores do Benzeno (GTB), escolhidos por seus pares entre os eleitos para as Comissões Internas de Prevenção de Acidentes, que institui a vigilância ao benzeno como uma prioridade de ação para as CIPA das empresas cadastradas, e estabelece concretamente a possibilidade de realização de ações de chão de fábrica, ou seja de exercício do controle da exposição pelos próprios expostos. Dessa forma, a ação de acompanhamento do acordo passa a ser permanente, pois é compartilhada com os trabalhadores no seu cotidiano de trabalho.

- a criação da Comissão Nacional Permanente do Benzeno, com o propósito de ser uma instância de negociação e acompanhamento da implementação do acordo e da legislação, responsável também por complementar as lacunas não resolvidas até então no processo de discussão. Posteriormente foram criadas instâncias regionais para cumprir este papel localmente. O acordo e a legislação estão ainda em vigor e constituíram a base legal e de negociação dos últimos anos no Brasil, tendo sido complementados em diversos aspectos, alguns deles comentados aqui.

\section{Aspectos atuais da exposição ao benzeno no Brasil}

A experiência brasileira dos últimos 14 anos tem se concentrado na discussão e intervenção nas atividades industriais onde a existência do benzeno é notória e substantiva. A política de restrição da utilização deste 
produto, iniciada na década de 30 e que tem como principal marco histórico a proibição de sua comercialização em 1982, praticamente limitou seu uso a atividades industriais muito específicas e setorizadas, o que se consolidou com a Portaria conjunta 775 de 28 de abril de 2004, dos Ministérios da Saúde e do Trabalho, que diminuiu ainda mais o percentual de concentração deste produto aceita como contaminação. As atividades nas quais se encontra benzeno no Brasil atualmente podem ser divididas em três categorias. A situação de exposição e contaminação dos trabalhadores e da população é particular a cada uma delas.

$\mathrm{Na}$ primeira categoria estão as atividades industriais em que é permitida a produção, utilização e transporte de benzeno. Envolvem as cinco siderúrgicas integradas do Brasil, em que há produção de coque; a industria de extração e refino de petróleo em todas suas etapas; a industria petroquímica produtora de benzeno; as industrias químicas de segunda geração que utilizam benzeno; as empresas de transporte de produtos químicos que transportam benzeno (Brasil, 1995).

$\mathrm{Na}$ segunda categoria estão as atividades onde há utilização de solventes e suas misturas: industrias gráficas, de calçados, couros, borracha, colas, tintas e vernizes. A legislação não permite a adição do benzeno nos solventes e suas misturas. Mesmo estando o benzeno em quantidade muito reduzida atualmente - no máximo $0,1 \%$ desde dezembro de 2007 - isto não significa a inexistência de risco, sendo ainda possível serem encontrados 
produtos fora das especificações, com concentrações maiores do permitido pela Portaria 775/2004 (Brasil, 2004 ).

A terceira categoria inclui as gasolinas automotivas, que têm concentração máxima de benzeno permitida de 1\% e 1,5\%, dependendo do seu tipo, pela legislação da Agencia Nacional do Petróleo (ANP). Assim, trabalhadores de postos de gasolina e de oficinas mecânicas constituem grupos de risco importantes e pouco acompanhados em nosso país. A adulteração de combustíveis, problema grave e frequente em nosso meio, é muitas vezes feita com adição de mistura de solventes, o que potencializa em muito a possibilidade de encontrar-se concentrações bem mais elevadas de benzeno nos combustíveis, havendo relatos da ANP de concentrações de até $8 \%$ em gasolinas adulteradas (Brasil, 2005).

Não se pode esquecer que estas atividades, bem como toda combustão incompleta de substancias orgânicas, têm efeito importante na contaminação ambiental que atinge a população como um todo. Há um esforço importante em praticamente todo o mundo pela diminuição da emissão de benzeno na atmosfera, focado principalmente na diminuição das emissões industriais e dos veículos automotivos.

\section{Vigilância da Exposição ao Benzeno no período de 1995 a 2009.}

A vigilância da exposição ao benzeno nestes últimos anos tem sido feita com base no acordo e legislação de 1995 e seus desdobramentos, sendo referência para inúmeras ações envolvendo trabalhadores, órgãos públicos e 
empresas. Seus principais aspectos são o reconhecimento oficial do benzeno como cancerígeno, a consolidação da restrição de sua utilização e o estabelecimento de estratégias e formas de vigilância em que a participação dos trabalhadores tem papel fundamental. As ações têm se concentrado na primeira categoria, as industrias, não por desconhecimento da importância das outras categorias, mas pelas dificuldades inerentes a este tipo de atividade e pela necessidade de definição de prioridades.

O relato de algumas experiências permitirá, no entanto, ver que a possibilidade de superação de alguns destes limites já está em andamento. Além de focadas nas atividades industriais típicas, as ações são bastante regionalizadas, obedecendo ainda a lógicas políticas e sociais, como será descrito, embora muitas vezes não sejam de fácil compreensão. Como parte da lógica de funcionamento deste quarto período, uma parte significativa da abordagem será feita por setores: siderúrgico, petroquímico e químico, petróleo; uma outra por região. Alguns casos críticos, no entanto, não poderão ser deixados de lado, até por sua grande influência no processo como um todo.

\section{De novo a Cosipa}

Em 1995 as atividades da Comissão Interinstitucional sobre Leucopenia na Cosipa, comissão que havia deixado de funcionar em 1989 e que voltou a se reunir em 1994, foram redirecionadas para o acompanhamento do Programa de Melhorias Ambientais, definido após entendimentos entre o Delegado Regional do Trabalho, o Procurador Geral do Trabalho e o Presidente da Cosipa. No 
segundo semestre desse ano, no entanto, a empresa foi multada em mais de um milhão de reais pela Cetesb, após ter sido responsável por um vazamento de gás de coqueria de tal proporção que atingiu o centro da cidade de Cubatão, situado a mais de cinco kilometros da usina. Foi comprovado ainda que, mais uma vez, a empresa não havia cumprido o cronograma de mudanças ambientais que ela mesma havia proposto e que havia sido aceito pela Cetesb e pela DRT-SP. Conforme registrado em ata de reunião, com vasta documentação em fotografias e filmes feitos em inspeção e apresentados por ocasião da discussão da fiscalização realizada no Ministério Público do Trabalho em julho de 1996, o Presidente da Cosipa afirmou não existir "trabalho em coqueria sem emanação de gases inclusive pelas portas" e referiu ter encontrado, ao assumir a presidência, "situação adversa com o comprometimento de todo o parque industrial" (Costa, 1996a).

Ao mesmo tempo em que a empresa tinha todos estes graves problemas de descontrole ambiental, que lembravam a situação de 1980 diagnosticada pela Fundacentro, num claro retrocesso decorrente da situação de degradação pré-privatização e ainda vigente na transição, havia grande pressão do INSS e da própria empresa pelo retorno dos trabalhadores leucopênicos, alguns afastados por mais de 10 anos sem qualquer definição sobre sua situação. Esta discussão, que seria feita nacionalmente, na negociação do acordo e da legislação, junto com a discussão dos direitos dos trabalhadores que tinha como item central a proposta de estabilidade no emprego, não chegou a qualquer resultado. $O$ patronato não concedeu nenhum direito aos 
trabalhadores doentes, ficando este item para discussão posterior, sem nenhum resultado positivo. Ainda em 95, a Comissão estabeleceu então critérios para a aposentadoria dos afastados, que resultou na aposentadoria de centenas de trabalhadores, e possibilitou o início da discussão de áreas de possível retorno ao trabalho. No entanto, ao começar a discutir os critérios para retorno, a empresa afirmou não seguir a norma legal, gerando assim um impasse que não foi resolvido até o presente momento, e que tramita na Justiça em um longuíssimo processo de Ação Civil Pública, atualmente na terceira instancia, tendo sido vencido nas duas primeiras instâncias pelo Ministério Público do Trabalho, assessorado pela DRT e pela Fundacentro.

Diversos relatórios foram produzidos pela DRT e pela Fundacentro entre 1996 e 1999 subsidiaram a Ação Civil Pública movida pelo Ministério Público do Trabalho contra a Cosipa. Entre os achados relevantes até o momento, destacam-se:

- uma incidência de 46,95\% de alterações hematológicas em cinco anos de acompanhamento da série histórica de hemogramas de 328 trabalhadores da coqueria, sendo $15,28 \%$ destas alterações persistentes em três ou mais exames, segundo relatório feito em 1996 pela DRT-SP. As conclusões do relatório sugerem que as alterações em 52 trabalhadores podem significar intoxicação por benzeno que, somadas às constatações de riscos ambientais mostrariam uma situação de descontrole ambiental e epidemiológico (Machado et al., 2003.). 
- o afastamento de um trabalhador, em 1997, com um quadro de Leucemia Mielóide Crônica, reconhecida pela Previdência Social como relacionada com exposição a benzeno. Este trabalhador viria a falecer em 2007.

- a determinação de fechamento de 14 unidades da Cosipa, feita em 1998 pela Cetesb, ao ser publicada a Lei do Crime Ambiental que responsabilizava também o funcionário público em situações de contaminação ambiental significativas. A empresa não cumpriu a determinação e conseguiu uma liminar contra a proibição de funcionamento. Pouco depois, uma Medida Provisória suspendeu a aplicação da lei.

- um novo relatório feito pela DRT e Fundacentro, em janeiro de 2001, fundamentando a relação com exposição a benzeno de seis casos novos em trabalhadores da Cosipa, que haviam sido afastados com Comunicação de Acidente de Trabalho (CAT), que foram "anuladas" pela instância superior da Previdência Social que posteriormente reconheceu apenas quatro desses casos.

- a Ação Civil Pública foi vencida pelo MPT em primeira instância em 2004, mas este recorreu da decisão por discordar dos valores das multas decididos pela Justiça, que Ihe pareceram baixos. Em 2007 o MPT ganhou seu recurso na segunda instância.

- a morte de três trabalhadores com leucemia em 2007. Um deles, afastado desde 1987 por leucopenia, desenvolveu no início do ano uma Leucemia Mielóide Aguda e faleceu seis meses depois. Outro, afastado com Leucemia Mielóide Crônica em 1997, faleceu em consequencia da leucemia. 
Um terceiro, jovem trabalhador de 24 anos, havia desenvolvido uma Leucemia Linfóide Crônica em 2004, tendo sido afastado e tratado com um transplante de medula óssea. Após sua recuperação, voltou a trabalhar na Cosipa no início de 2007, tendo uma recidiva e vindo a falecer no meio do ano.

\section{O relatório das siderúrgicas}

Ao fazer o relato da situação da Cosipa a impressão é que o Acordo e a Legislação do benzeno de 1995 não trouxeram qualquer mudança. De fato, há muita dificuldade com o setor siderúrgico, e diversas questões não foram equacionadas até agora. Um momento importante foi o processo de visitas às siderúrgicas, que permitiu à representação do setor público (a "bancada de governo" da Comissão Nacional Permanente do Benzeno, como é conhecida), construir uma visão do setor até então inexistente.

Entre as conclusões do relatório destas visitas, consta

- que as empresas siderúrgicas não caracterizavam como áreas de riscos setores importantes que utilizam gás de coqueria, e consequentemente trabalhadores da manutenção, do tratamento de efluentes líquidos e de locais que possam ter ou estar próximos de vazamentos de drenos ou flanges das linhas de gases de coqueria, que percorrem todas as usinas, não estavam sendo avaliados, como deveriam, quanto ao seu risco de exposição;

- que não havia por parte das siderúrgicas o reconhecimento da mudança de paradigma quanto ao fato do benzeno ser uma substância 
cancerígena para a qual não havia limite seguro de exposição e que o VRT não era um valor utilizável para o pagamento de adicional de insalubridade;

- que deveria haver uma preocupação com a exposição dos trabalhadores ao conjunto de substâncias tóxicas e cancerígenas presentes no processo produtivo siderúrgico, em especial nas coquerias, inclusive aos Compostos Orgânicos Voláteis (COVs) e aos Hidrocarbonetos Policiclicos Aromáticos (HPAs), e que deveria haver uma atenção especial aos aspectos clínico-epidemiológicos, em particular à ocorrência de câncer nestes trabalhadores;

- que havia uma parceria mórbida entre as siderúrgicas e o Instituto Nacional de Seguridade Social, visando reduzir ao máximo o número de casos, o que não resistiria a uma busca ativa sistemática como havia ocorrido na Cosipa em 1996. Na visita à Cosipa, o Sindicato de Trabalhadores Metalúrgicos da Baixada da Santista denunciou a existência de quatorze trabalhadores intoxicados por benzeno, não reconhecidos pela empresa e pelo INSS à época; a Cosipa negou a existência de qualquer caso de alteração hematológica relacionado com exposição benzeno em suas dependências. Na Açominas, havia oito casos reconhecidos, quatro na ativa e quatro afastados; esta empresa era a única na época que utilizava, de forma pioneira no Brasil, em parceria com a Universidade Federal de Minas Gerais, o ácido trans-trans mucônico como indicador biológico de exposição. A CSN informou que entre 1986 e 1997 setenta e seis trabalhadores foram afastados por leucopenia e três por plaquetopenia, permanecendo naquela data dezenove afastados; dezoito 
haviam sido aposentados, dezessete demitidos e vinte e cinco tinham tido alta. A Usiminas e suas terceiras apresentaram as séries históricas para análise, não informando se havia trabalhadores com alterações hematológicas. A CST informou não haver qualquer tipo de doença entre os trabalhadores em suas dependências, sequer Hipertensão Arterial Sistêmica. Como é evidente, a situação era muito pouco favorável para o diálogo, permanecendo assim por algum tempo.

O relatório, bastante polêmico, gerou uma crise que só foi superada no final de 2002 com um entendimento entre as bancadas participantes da Comissão Nacional do Benzeno. Favoreceu este entendimento uma oficina da bancada de governo sobre as siderurgias, que definiu as prioridades para 0 trabalho com este setor: necessidade de se estabelecer uma política de longo prazo para as coquerias, com soluções de maior amplitude; mudanças nas formas e critérios das avaliações ambientais; utilização da discussão da política de boas práticas como forma de interlocução entre as partes.

\section{A entrada do setor petróleo na discussão}

Tão singular quanto a importância da siderurgia na experiência brasileira sobre benzeno é a ausência do setor petróleo até praticamente o final da década de 1990. É bastante curioso, pois em outros países a industria do petróleo era bastante atuante e preocupada em relação aos temas envolvendo benzeno havia muitos anos. Desde as já citadas manifestações do Instituto Americano do Petróleo (API) sobre limite de exposição ao benzeno nos anos 
40/50, até a participação da industria do petróleo como observadora no grupo tarefa que produziu o documento da Organização Mundial da Saúde sobre benzeno, publicado no número 150 da série Environmental Health Criteria (World Health Organization, 1993). Dos cinco observadores que participaram, três são ligados a companhias de petróleo, dois a Exxon Biomedical Sciences e um a Mobil Research. Estas são as duas maiores empresas das chamadas "sete irmãs", desmembramento feito da Standard Oil, empresa do magnata Rockfeller, no histórico processo de controle do monopólio do petróleo nos Estados Unidos no início do século XX (Yergin, 1992). Como todas as grandes corporações petrolíferas, têm centros de pesquisa e investem em estudos sobre os danos relacionados a seus produtos que podem ser provocados ao ambiente e à saúde humana, pois é notório o quanto é questionado o papel do petróleo e das emissões dos produtos derivados de seu refino no mundo atual.

A postura destas empresas é, portanto, muito mais do que defensiva, estando inseridas no que neste estudo foi denominado de "questão química", e atuam com iniciativas permanentes de discussão e promoção de estudos, participando do debate mundial e financiando pesquisas e projetos. Deve ser destacada também a grande importância dada pela industria do petróleo à sua imagem, às relações com o público e as instituições e à pesquisa num sentido bastante amplo, não apenas de produtos ou mercados, mas também científicas e mesmo sobre problemas de saúde. Atualmente, a indústria do petróleo tenta mudar sua imagem, vinculada de forma muito forte à contaminação ambiental no mundo inteiro, ligando-a com a idéia da produção de energia e de industria 
ecológica. Sua presença no debate internacional sobre benzeno é tão certa quanto a da industria do tabaco no debate sobre hábito de fumar e câncer de pulmão.

A postura surpreendente da industria petrolífera brasileira, na contra mão da industria internacional, começou a mudar partir de 1996. Contribuíram de forma decisiva para modificar este cenário a presença de um representante dos trabalhadores bastante ativo na Comissão Nacional Permanente do Benzeno, Roberto Odilon Horta, da Federação Única dos Petroleiros, e o início das atividades de formação de trabalhadores em São Paulo, no ano de 1996, com uma oficina de trabalho com os petroleiros das quatro refinarias da Petrobrás e de algumas unidades de armazenamento de petróleo do estado. A oficina foi realizada em três etapas, e foi a primeira discussão com a categoria dos petroleiros em que se começou a levantar os problemas de exposição e adoecimento por benzeno nos locais de trabalho no estado.

As gerências locais, em negociação com o sindicato, haviam concordado com a participação, na oficina, dos representantes dos trabalhadores e de técnicos da empresa. No final da manhã do dia do início da oficina - que ocorreria à tarde - veio orientação "do Rio" para que os técnicos da empresa não participassem, criando um mal estar e dificultando a participação de vários trabalhadores. Na prática, a oficina acabou se tornando um curso para sindicalistas, o que não era o seu objetivo inicial. Esta situação mostra o conflito entre as possibilidades das gerências locais, bem mais favoráveis ao diálogo, 
e as orientações do corporativo da empresa, emitidas do Rio de Janeiro, e sempre restrita a uma perspectiva jurídico-administrativa.

Passados 12 anos, no entanto, o envolvimento do setor petróleo se modificou substantivamente. Sendo as atividades de formação a base do processo de discussão com os trabalhadores, os cursos passaram a ocorrer de forma sistemática em São Paulo e, já em 1997, após a primeira oficina nacional de técnicos do serviço público, sindicalistas e trabalhadores de empresas se transformaram em parte central da estratégia nacional de ações conjuntas que foi estabelecida. Assim, as atividades de discussão no setor petróleo se expandiram para todo o país e se ampliaram para áreas em que não havia reconhecimento do risco de exposição ao benzeno, como as plataformas de exploração de petróleo e as áreas de dutos e tancagem. Houve uma verdadeira inversão da situação, e hoje a Petrobrás se tornou o principal foco de discussão dos riscos do benzeno no Brasil, havendo mobilização de dezenas de trabalhadores nas reuniões da Comissão Nacional e das Comissões Regionais que ocorrem periodicamente.

Um dos motivos desta participação significativa se deve ao fato dos petroleiros terem exposição importante a uma grande quantidade de substâncias químicas, em especial hidrocarbonetos, dentre eles o benzeno. Esta exposição é muito pouco valorizada no dia a dia de suas atividades e, de uma maneira general, incorporada fatalisticamente como "risco inerente à profissão", compensado historicamente com a aposentadoria especial. A mobilização sobre os riscos do benzeno veio preencher este vazio, num 
momento de retirada de direitos, inclusive o da aposentadoria especial, e se constituiu em alternativa num período de recuo e resistência do movimento sindical na segunda metade dos anos 90. Embora esta conjuntura tenha se modificado, e o setor petróleo esteja em grande expansão no Brasil, a discussão sobre o benzeno e os riscos químicos em geral na Petrobrás, embora em patamar muito superior ao inicial, ainda tem questões fundamentais a serem resolvidas. Este setor, de alguma maneira, pode ser classificado, do ponto de vista da exposição ao benzeno, num estágio intermediário entre a siderurgia e a petroquímica; sua importância na discussão para uma abordagem transformadora da questão química é, no entanto, muito maior do que a da siderurgia. Dois casos críticos merecem destaque no setor petróleo: o da Refinaria de Manguinhos e o da Refinaria Presidente Bernardes de Cubatão.

O caso da Refinaria de Manguinhos teve seu inicio em 1990 com a identificação dos primeiros casos de leucopenia na empresa. Em 1992 foi aprovada uma lei estadual que proibia a adição de chumbo tetra-etila na gasolina, o que levou a refinaria a comprar nafta reformada da Petrobrás para aditivar sua gasolina. Esta nafta possuía um teor bem mais elevado de benzeno e, segundo o sindicato, provocou um aumento significativo no número de casos. Em 1994, uma nova mudança tecnológica, com a entrada em operação da Unidade de Reforma Catalítica, aumentou ainda mais o número de casos. Em 1995, com o novo acordo e a legislação, foi eleito um Grupo de Trabalhadores do Benzeno que começou, ainda sem apoio da empresa, a fazer um levantamento da situação. Em 1996 a empresa então decidiu encaminhar 
quarenta trabalhadores para avaliação no HemoRio, instituto de hematologia da Secretaria de Estado da Saúde do Rio de Janeiro. Finalmente, em 1998, a empresa aceitou a participação dos trabalhadores no grupo que estava avaliando o problema. Nesse mesmo ano o grupo de trabalhadores investigado passou a cinquenta, e houve uma mudança no controle acionário da empresa. O protocolo de acompanhamento do HemoRio entre 1996 e 1999 informou que, de quarenta e sete trabalhadores investigados, seis estavam ainda em acompanhamento, dois estavam afastados pelo INSS, dezenove haviam sido liberados e vinte tinham sido demitidos (Horta, 2005). Em 2004 a empresa foi fechada devido a dificuldades financeiras. Antes disso haviam sido feitas inúmeras denuncias de adulteração de combustíveis, inclusive pela imprensa. A situação dos trabalhadores doentes e em investigação não foi resolvida até o momento.

No caso da RPBC, o Sindicato de Trabalhadores apresentou denúncia ao Ministério Público do Trabalho (MPT), referindo a existência de casos de intoxicação por benzeno que não eram reconhecidos e continuavam expostos, correndo o risco de ter um agravamento do quadro. O MPT constituiu um Procedimento Preparatório e organizou um grupo técnico em agosto de 2004, para dar encaminhamento ao Procedimento e fazer um levantamento da situação através de entrevistas com esses trabalhadores, discussões coletivas com a participação dos trabalhadores e do sindicato, verificação de documentos produzidos pela empresa e verificações in loco na empresa. A RPBC é uma das mais antigas refinarias do país, inaugurada em 1956, e possui a mais antiga 
fábrica de benzeno em funcionamento no país, que opera desde o final dos anos 50.

Em outubro de 2004 um operador da área de transferência e estocagem, do setor de tratamento de resíduos industriais - um dos locais de maior risco de contaminação por hidrocarbonetos, inclusive benzeno - morreu com um quadro de Leucemia Mielóide Aguda, que foi relacionado pelo grupo técnico com a exposição importante ao benzeno que teve ao longo de sua vida profissional. $\mathrm{O}$ resultado da investigação feita pelo grupo técnico apontou para uma situação grave de exposição a benzeno em todas as áreas da empresa, e de contaminação do grupo de trabalhadores avaliado, confirmando a ocorrência de intoxicação por benzeno nos casos investigados, inclusive no caso fatal, e identificando falhas severas no sistema de vigilância à saúde aplicado na empresa, entre outros problemas.

A investigação feita no grupo de trabalhadores, ao apontar para a consistência da suspeita de inúmeros casos de intoxicação por benzeno, sem que o acompanhamento da saúde dos trabalhadores na empresa fosse adequado e confiável, fundamentou a necessidade de ampliar a investigação para verificar a situação do conjunto de trabalhadores da refinaria, através do monitoramento da série histórica de hemogramas. Para tanto, foi proposta uma revisão das séries históricas de todos os trabalhadores, e um aprofundamento da investigação diagnóstica do grupo de 15 trabalhadores caracterizados como casos de intoxicação em dezembro de 2004 e afastados da refinaria em janeiro de 2005. 
A partir dessas constatações, a empresa e o sindicato de trabalhadores firmaram termo de compromisso, que está em acompanhamento até o momento, com programa de estudos e mudanças na empresa visando modificar a situação de risco existente. Apesar das inúmeras dificuldades de diálogo. o termo de compromisso está em andamento, em fase de avaliação final para revisão e formulação de novas metas.

\section{A regionalização}

Outro elemento bem sucedido na experiência do benzeno foi a regionalização das ações. Na oficina nacional realizada em 1996, esta decisão foi tomada como alternativa para a construção de uma ação integrada entre as várias instituições envolvidas: SUS, DRT e Sindicatos. Foi estabelecida como prioridade a implementação do acordo e da legislação nos sete estados brasileiros identificados como grandes produtores ou consumidores de benzeno, que tinham empresas cadastradas no Ministério do Trabalho. Para tanto foi definida a organização de pelo menos quatro grupos regionais nos estados de São Paulo, Rio de Janeiro, Bahia e Rio Grande do Sul.

No começo houve resistência por parte do patronato em aceitar essa forma de atuação e apenas na Bahia, onde havia preponderância do setor petroquímico e químico, mais abertos ao diálogo, foi formada uma comissão estadual com caráter tripartite. Com o tempo, no entanto, não apenas outras comissões foram sendo criadas nos demais estados prioritários como finalmente em 2002, com a mudança iminente de governo e a mudança da 
representação da siderurgia, que passou a ser feita pela Açominas, siderúrgica mais moderna e com políticas mais próximas da indústria petroquímica, foi acordado o reconhecimento do setor patronal das comissões regionais como instâncias de acompanhamento do acordo e da legislação nos estados. As comissões vêm funcionando com dinâmicas que variam de acordo com cada estado, passando às vezes por períodos difíceis no relacionamento entre as partes, particularmente nas regiões em que há menos tradição de práticas de negociação, ou quando ocorrem situações de crise.

\section{Principais pontos do quarto período}

O quarto período foi marcado por uma mudança substantiva na abordagem do problema do benzeno, reflexo das mudanças ocorridas no mundo do trabalho que levaram a uma perda importante da capacidade de mobilização dos trabalhadores e de intervenção dos órgãos públicos. A caracterização do benzeno como substância cancerígena, no entanto, somado ao fato de ter havido uma concentração ainda maior da produção e utilização do benzeno em determinados setores produtivos permitiram que, ainda que tenham perdido força de negociação, estes setores tenham permanecido em posição relativamente privilegiada em relação a outros setores produtivos. Numa conjuntura de grandes retrocessos na maior parte das discussões da área de saúde do trabalhador, as ações relacionadas ao benzeno neste período não tiveram a mesma má sorte. 


\section{Regulamentação}

O quarto período foi fértil em regulamentações. Seu início é demarcado, em 1994, pela Portaria de reconhecimento do benzeno como substância cancerígena. Até então, apenas quatro substâncias, de uso muito reduzido e localizado e praticamente desconhecidas, eram reconhecidas como cancerígenas. Esta legislação era portanto, até então, totalmente inócua. A introdução do benzeno no Anexo 13 da NR 15 foi bastante positiva, e a retirada dos limites de tolerância ambientais e biológicos teve grande repercussão, pois os limites funcionam como mecanismos de regulação jurídico-administrativa das empresas. Quando deixaram de existir, as empresas se sentiram pressionadas, pois passaram a não poder manter a justificativa de que suas dependências estavam "dentro dos padrões legais".

Após um ano e meio de negociações começaram a ser publicadas as regulamentações que constituíram o corpo da legislação sobre a prevenção da exposição ao benzeno nesta última fase no Brasil. São numerosas, detalhadas e tratam de diversos aspectos relacionados à questão:

- Portaria de 1995 que altera o item "substâncias cancerígenas" do Anexo 13 da NR 15 e inclui o Anexo 13-A nessa NR. Este anexo é específico sobre o benzeno, e nele estão contidas as principais determinações acordadas no processo de negociação e transformadas em lei. Além do anexo há um acordo propriamente dito, também publicado, que contém diversas orientações que pretendiam conduzir a sequência do processo de negociação. Algumas foram bem sucedidas, outras nem tanto. 
- Instruções Normativas publicadas em 1995 que complementam a Portaria do Anexo 13-A: uma sobre avaliação ambiental, extremamente detalhada, peça singular da higiene ocupacional brasileira, que será comentada mais adiante; outra, sobre vigilância da saúde dos trabalhadores, que incorpora os princípios básicos já comentados das normas da Secretaria de Estado da Saúde de São Paulo de 1992 e da Previdência Social de 1993.

- Portaria, publicada em 1996, de instalação da Comissão Nacional Permanente do Benzeno, instância tripartite de negociação que funciona até o presente momento com um êxito significativo, apesar das muitas dificuldades, dos inúmeros momentos de crise e de alguns períodos curtos de interrupção de suas atividades. O principal fracasso deste processo foi que não conseguiu superar o impasse referente aos direitos dos trabalhadores afastados, que não havia tido nenhum resultado positivo na negociação anterior, processo muito ligado ao reconhecimento das doenças do trabalho no país, que, como já foi visto, é um dos pontos centrais e certamente o mais polêmico.

- Portaria de maio de 1998, que estabeleceu os prazos para substituição do benzeno na produção do álcool anidro. Foram prazos distintos para as diferentes regiões., pois as safras ocorrem em épocas diferentes: 31/12/1998 para a região centro sul e 31/05/1999 para o nordeste. Embora a quantidade de benzeno usada por este setor fosse relativamente pequena, era o principal responsável pelo transporte difuso de benzeno por caminhões no país.

- Procedimentos para a utilização do indicador biológico de exposição ao benzeno, o ácido trans-trans mucônico, que adequou o indicador de exposição 
aos índices de exposição acordados, abaixo de 2,5 ppm, publicados em dezembro de 2001.

- Regulamentação, ainda em dezembro de 2001, pela Agencia Nacional do Petróleo, do teor de benzeno na gasolina, estabelecendo o limite máximo de $1 \%$ na gasolina comum tipo $\mathrm{C}$ e $1,5 \%$ na gasolina premium.

- Nota técnica de julho de 2002, explicitando a abrangência do campo de aplicação do acordo e legislação do benzeno, em função da resistência da Petrobrás a aceitar a discussão do risco de exposição a benzeno em plataformas, terminais, bases de distribuição de petróleo, gás e derivados.

- Portarias 775 e 776 de abril de 2004. .A primeira, interministerial, dos Ministérios da Saúde e do Trabalho, revisa a portaria de 1982, restringindo ainda mais o percentual de benzeno aceito como contaminação nos produtos acabados, que passa de $1 \%$ a $0,1 \%$ em dezembro de 2007 . A segunda, do Ministério da Saúde, dispõe sobre os procedimentos relativos à vigilância da saúde dos trabalhadores expostos ao benzeno. Esta norma aprofunda e amplia os conceitos da instrução normativa de 1995, procurando manter os princípios mais protetores estabelecidos no início da década de 1990.

- Nota Técnica do Ministério do Trabalho, ainda em 2004, apresentando as alterações negociadas e aprovadas na Comissão Nacional Permanente do Benzeno, ampliando os direitos dos trabalhadores nos Grupos de Trabalhadores do Benzeno.

- Regulamentação da Portaria que definia as competências da União, Estados e Municípios no que se refere à área de vigilância ambiental, em 2005, 
pela Secretaria de Vigilância em Saúde do Ministério da Saúde. A regulamentação estabeleceu como uma das prioridades da Coordenação Geral de Vigilância Ambiental dessa Secretaria os procedimentos de vigilância epidemiológica das doenças e agravos á saúde humana associados a contaminantes ambientais, dentre eles o benzeno.

- "Protocolo de Riscos Químicos : atenção à saúde dos trabalhadores expostos a benzeno" e "Protocolo de Câncer Relacionado ao Trabalho: Leucemia Mielóide Aguda / Síndrome Mielodisplásica decorrente da exposição ao benzeno", publicados em 2006 pelo Ministério da Saúde, através da Coordenação Geral de Saúde do Trabalhador. Estes protocolos atualizam e tentam ampliar para alguns setores específicos do SUS a discussão do diagnóstico da intoxicação por benzeno (Brasil, 2006)

No momento existe a expectativa de que seja publicada Nota Técnica regulamentando o cadastramento e descadastramento de empresas, item recentemente negociado na Comissão Nacional Permanente do Benzeno, depois de muitos anos sem que se conseguisse avançar em nenhum item nesta comissão.

\section{Exposição}

Do ponto de vista da exposição ao benzeno, muitos elementos sugerem a ocorrência de mudanças importantes neste período. Há, no entanto, dificuldade de coleta de informações sistematizadas sobre esta situação do ponto de vista quantitativo. Apesar do detalhamento da Instrução Normativa 1, não há uma tradição de acompanhamento das práticas de higiene ocupacional 
no país, e esta dificuldade não foi superada na experiência do quarto período. O elemento mais significativo, no entanto, do ponto de vista qualitativo, é a restrição à exposição com a própria caracterização do benzeno como cancerígeno e a criação do Valor de Referência Tecnológico. Ainda que no começo tenha havido muita dificuldade de compreensão quanto ao conceito de "nenhuma exposição permitida", dificuldade que persiste até hoje em alguns setores e empresas, com o tempo a idéia que todo esforço deve ser feito para evitar qualquer tipo de exposição a qualquer concentração de benzeno foi ganhando cada vez mais espaço.

Após muitas tentativas, nos primeiros anos, para que as empresas apresentassem dados e se pudesse fazer uma discussão coletiva, na tentativa de se ter uma apreciação da situação nacional quanto ao estado da arte da exposição ao benzeno nas empresas cadastradas, o balanço feito pela bancada patronal na oficina sobre avaliação ambiental realizada em 2003 frustrou todas as expectativas. O resultado apresentado foi que não havia homogeneidade entre as empresas, cada uma fazendo a sua avaliação conforme padrões diferentes.

O acompanhamento que é feito pelas Comissões Regionais, no entanto, embora de fato não permita uma visão mais geral da situação brasileira no momento atual, é suficiente para evidenciar uma diminuição substantiva nos padrões de exposição se comparados aos existentes há vinte anos atrás. Certamente é importante que sejam feitos levantamentos e estudos 
quantitativos, mas as limitações para tal continuam grandes, numa realidade que difere de acordo com cada setor considerado.

No setor siderúrgico o controle da contaminação ambiental é reconhecidamente mais difícil. Ainda assim, a situação neste setor evoluiu para melhor em relação aos anos 80 , em especial com o fechamento, na maior parte das usinas, das fábricas de benzeno que operavam na área de carboquímicos. A única exceção é a Açominas que ainda mantêm a fabricação de benzeno, mas têm um padrão diferenciado. O setores petroquímico e químico têm uma boa aceitação das propostas de boas práticas, principal ferramenta do setor público para discussão e implementação da política de não exposição. A diminuição da exposição neste setor é bastante significativa e pode ser percebida pelos indicadores quantitativos em diversas empresas, mas é bastante evidente pela implementação das principais boas práticas na maior parte de suas empresas.

Entre estas boas práticas destacam-se: monitoramento de benzeno online em áreas críticas de exposição; carregamento de caminhões por baixo em sistema fechado "bottom-load"; programas de substituição de bombas; medição de tanques com radar evitando sua abertura; unidade de recuperação de vapores. O setor petróleo, que teve inicialmente bastante resistência em reconhecer o risco de exposição a benzeno em suas atividades, tem reagido positivamente à política de boas práticas nos locais onde existem Comissões Regionais ativas, embora isto não ocorra sem traumas em situações de crise. 


\section{Agravos à saúde}

Houve uma queda substantiva na identificação de agravos à saúde neste período. As mudanças ocorridas justificam parcialmente a diminuição do número de casos, pois certamente há menos exposição neste período e menos ocorrência de doenças em geral relacionadas ao benzeno. No entanto, uma parte importante dos casos deixaram de ser identificados, e outros casos, quando diagnosticados, não conseguem reconhecimento oficial da Previdência Social. Também aqui os dados são escassos e difíceis de serem analisados, não permitindo dizer com convicção que representam o ocorrido no período considerado.

Alguns comentários podem ser feitos. Os vários esforços de regulamentação negociados, da instrução normativa de 1995 ao protocolo de 2006, surtiram pouco efeito, pois a diminuição no número de diagnósticos e a dificuldade para o reconhecimento dos casos pela previdência social, que já existia no início dos anos 90, não se modificaram com estas regulamentações. Os casos que foram aceitos demandaram em geral mobilização sindical e articulação intersetorial. Neste período, como esperado, começaram a surgir casos de leucemia, tendo sido identificados cinco deles em São Paulo: três já relatados de trabalhadores expostos na Cosipa; um na RPBC; e uma trabalhadora, secretária da manutenção na Petroquímica União, que desenvolveu uma Leucemia Mielóide Aguda e faleceu. As tentativas de acompanhamento, pelo poder público, das séries históricas de hemogramas 
dos trabalhadores expostos, em particular a proposta de criação de um sistema de monitoramento, não foram bem sucedidas.

Um setor que historicamente não é acompanhado é aquele dos trabalhadores de postos de gasolina. Há algumas iniciativas regionais de algumas das Comissões Estaduais do Benzeno, principalmente no Paraná. Em atividade conjunta com o Ministério da Previdência Social, por solicitação do Grupo de Trabalho de Saúde do Trabalhador da Associação Brasileira de PósGraduação em Saúde Coletiva, foi feito por esse Ministério o levantamento das doenças malignas de tecido linfático e hematológico, que se supõe relacionadas com benzeno (classificadas pela Classificação Internacional de Doenças com CID C81 a C96 ou D60 a D64), e foram correlacionadas com os trabalhadores registrados no comercio varejista de combustíveis (Classificação Nacional de Atividades Econômicas (CNAE) 50-50), nos anos 2004, 2005 e 2006.

Foram concedidos em 2004, para trabalhadores registrados nessa CNAE, vinte e cinco auxílios-doença, sendo quatro Leucemias Mielóides e duas Aplasias; em 2005, foram vinte um auxílios-doença, com seis Leucemias Mielóides; e vinte e dois em 2006, sendo cinco Leucemias Mielóides e três Aplasias. Esta incidência de doenças malignas hematológicas nesta categoria profissional, embora demande maior aprofundamento dos dados, reforça a idéia da gravidade desta situação. Com a implantação do chamado Nexo Técnico Epidemiológico, novas informações sobre doenças hematológicas relacionadas com atividades estabelecidas por critérios da previdência passaram a ser reconhecidas. De janeiro a julho de 2007, de acordo com levantamento feito no 
site do MPAS, haviam sido reconhecidos 10 casos de Aplasia de Medula, 12 casos de agranulocitose (leucopenia, D-70), 34 Leucemias Mielóides, 10 Síndromes Mielodisplásicas e 10 Leucemias Linfóides como relacionados com o trabalho. Não era possível saber se esta relação era com o benzeno ou com outro agente.

\section{Ações}

Neste período a principal característica foi o desenvolvimento de ações a partir da Comissão Nacional Permanente do Benzeno. Inicialmente com marca muito acentuada do tripartismo, depois com uma grande diversificação na forma de atuação. A organização das comissões regionais e posteriormente a articulação de diversas redes de ação permitiram uma flexibilidade e autonomia operacional que vêm possibilitando a manutenção das ações. 


\section{DISCUSSÃO}

A pergunta condutora deste estudo foi se as restrições legais impostas à exposição ao benzeno no Brasil influenciaram em eventuais avanços ocorridos na prevenção da exposição a esta substância no país. Responder a esta pergunta não é uma tarefa simples. Em primeiro lugar, é um período histórico longo, em que há muitas variações nas restrições propostas e nas políticas de prevenção. Já aparecem então algumas necessidades prementes: ao mesmo tempo em que é preciso dividir este período histórico em alguns ciclos, que possam ser analisados com mais propriedade por suas características internas, também é preciso identificar se as restrições estabelecidas tiveram algum efeito prático, se elas foram seguidas e, se o foram, se o seu cumprimento foi capaz de proteger efetivamente os trabalhadores dos riscos à saúde provocados pelo benzeno. A opção por refazer o percurso histórico da utilização do benzeno, da sua produção industrial, assim como da produção técnico-científica sobre a saúde dos trabalhadores a ele expostos, e dos conflitos sociais que tiveram repercussão, embora tortuosa, permitiu a recuperação de inúmeros elementos presentes neste processo. Foi também muito ilustrativa a busca de relações com a experiência internacional, pois chamou a atenção a frequencia com que situações que ocorreram em países industrializados se repetem nos países de industrialização tardia.

No caso do benzeno é visível um fluxo migratório que leva o conjunto benzeno, solventes e aplasias dos Estados Unidos e da Europa Central, na 
forma em que eram utilizados e com as consequencias que tinham ali até os anos 50, para a Itália no pós guerra, pouco depois para a Turquia e quase numa seqüência para China e o Brasil nos anos 60 e 70 . Com todo o cuidado e as diferenciações que perioridizações e comparações demandam, o que parece semelhante é que, nos Estados Unidos e na Europa Central, as medidas de prevenção, que tiveram seu início na década de 20 e na pessoa de Alice Hamilton uma figura emblemática (Hunter, 1955), e que se consolidaram no pós-guerra, modificando o padrão de uso e de morbidade provocada por esta substância, não chegaram nos outros países junto com o benzeno. As concentrações ambientais muito elevadas e as aplasias consequentes a estas exposições vão ocorrer, simulando um efeito dominó, primeiro na Itália, depois na Turquia e na China.

Uma ressalva fundamental a ser feita é que a visibilidade do caso do Brasil só existe, na prática, para os brasileiros, já que na revisão da literatura técnico-científica internacional apenas se encontram referências a situações que ocorreram em alguns poucos países ou regiões: Estados Unidos, Europa do Norte e Central, Turquia e China. A Turquia deve ser destacada da Europa, pois sua presença está relacionada com os estudos de Aksoy, e não há relatos ou referências à situação de países vizinhos. Esta seleção com certeza não é geográfica, e reflete uma limitação na produção de conhecimento e uma dificuldade de se conhecer a realidade dos países periféricos, do ponto de vista do benzeno, que tem implicações bastante relevantes. Como foi identificado, há um fluxo migratório do benzeno, possivelmente mundial, e podemos visualizar 
seus efeitos em alguns países. Mas, em quantos países este fluxo ocorreu? O que aconteceu nesses países? Embora existam poucas informações sobre a situação mundial para além do relatado aqui, parece coerente supor que os agravos à saúde relacionados à exposição ao benzeno tiveram dimensão muito maior do que o que está na literatura, e o caso do Brasil é exemplo claro disto.

Temos, no Brasil, as evidências do grande aumento do uso do benzeno e sua presença descontrolada no processo produtivo, com exposições significativas de trabalhadores a concentrações muito elevadas desta substância. Os achados de aplasias medulares, no entanto, são absolutamente pontuais e reduzidos, não tendo correspondência com esta realidade, o que é bastante diferente desses outros países.

O atraso nas medidas de proteção também vem em ondas: 1963 na Itália; início da década de 70 na Turquia, muito próxima da orientação da OIT de 1971; meados para final da década de 70 na China, aparentemente na forma mais pragmática de uma orientação para a substituição do benzeno por tolueno ou xileno quando este fosse utilizado como solvente. A proibição do uso do benzeno como solvente só ocorreria no início da década de 80 no Brasil. Diferença interessante e importante é que, ao contrário dos outros países, em que a casuística é rica e dá lugar a estudos e achados que se tornaram clássicos, na medicina no Brasil praticamente não foram identificados casos, embora as condições de trabalho e exposição fossem praticamente as mesmas e, principalmente se comparamos com a Turquia, e mais precisamente com Istambul, onde os estudos de Aksoy tiveram lugar, o número de expostos no 
Brasil tenha sido muito superior neste período. De 1930 a 1982 foram identificados apenas oito casos de Aplasias de Medula relacionados com exposição a benzeno no Brasil, e pouco mais de 120 trabalhadores tiveram quadros considerados como alterações compatíveis com intoxicação por benzeno ou eventos "alerta". Na Itália, entre 1928 e 1975, foram diagnosticados aproximadamente 67 casos fatais de aplasia de medula relacionadas com exposição a benzeno. Na China, entre 1979 e 1981, foram 24 aplasias e 9 leucemias. Na Turquia, 34 casos de leucemia foram relacionados com a exposição a benzeno entre 1967 e 1975.

Há, é claro, várias diferenças entre estas experiências. Algumas características da Itália devem ser destacadas: sua grande tradição na Medicina do Trabalho desde Bernardo Ramazzini, mas também com a Clinica del Lavoro em Milão e o Instituto del Lavoro em Pavia, que são os dois principais locais de achados desta casuística, assim como a importância do movimento social, em especial entre os anos 1960 a 1985, com a construção do Modelo Operário Italiano de discussão da saúde do trabalhador, que teve repercussão internacional e certamente influenciou a ocorrência destas descobertas. A tradição da medicina na Turquia e as características do tipo de produção da indústria de calçados em Istambul também favoreceram a investigação da exposição dos trabalhadores e sua relação com o benzeno. Na China, como transparece nas publicações analisadas, há uma decisão de Estado para enfrentamento do problema. Mesmo que, curiosamente, apareçam elementos de tentativa de minimização da gravidade da situação o que, aliás, é prática 
comum de empresas e governos. Para além de ideologias e projetos políticos, o número de casos é prova contundente da necessidade de modificação da situação e possivelmente um dos fatores de mobilização do estado chinês. A disparidade da comparação entre o número de casos desses países e aquele do Brasil demanda um aprofundamento da análise da dificuldade de se fazer diagnósticos aqui, assunto que aparece em todos os períodos estudados.

A migração ou exportação de riscos em relação ao benzeno é um fenômeno muito evidente nestes casos. Siqueira, em seu livro "Dependent convergence", argumenta no entanto quanto à complexidade deste fenômeno, que poderá ser visto ao longo dos anos em especial no Brasil e na China. Em sua opinião, não há apenas exportação de riscos, também ocorrem fenômenos que envolvem tanto as corporações multinacionais quantos as nações periféricas e seus projetos de desenvolvimento. As empresas exportariam, dependendo das circunstâncias, além dos riscos, também tecnologias mais novas e mais limpas, padrões mais elevados de controle ambiental para pressionar as companhias menores e com isto ganharem vantagens competitivas sobre elas. Mais ainda, as corporações poderiam sofrer pressões dos mercados consumidores em seus países de origem para que evitem o duplo padrão, estejam onde estiverem. Quanto às nações em desenvolvimento elas não são simples receptoras de corporações especializadas em transferir riscos. Estas nações têm seus projetos nacionais, suas forças sociais, seus processos próprios enfim que, ainda que funcionem com uma lógica 
dependência, mantêm sempre uma margem de autonomia e um curso histórico próprio (Siqueira, 2003).

Voltando à pergunta central do estudo, é evidente, pelo relato, que não se pode dissociar as medidas de restrição de seu contexto sócio-histórico. Assim por exemplo, embora expressasse uma concepção técnico científica adequada e ajustada aos preceitos mais atualizados naquele momento, a proibição do trabalho de mulheres e menores não apenas caiu no vazio entre 1930 e 1960, como foi acintosamente desrespeitada entre 1960 e 1982, não tendo portanto contribuído com avanços na prevenção da exposição ao benzeno no Brasil. No que diz respeito ao estabelecimento do pagamento de adicional de insalubridade em 1972, não há relatos sobre eventuais consequencias desta legislação. Estas são constatações que demandam algumas considerações: como apontado anteriormente, o primeiro período sugere uma falta de concretude relacionada ao fato das quantidades de benzeno provavelmente serem muito pequenas. Somente há quantificação da produção e utilização de benzeno no Brasil a partir de 1960, mas sabe-se que estas quantidades eram muito pequenas, e foram aumentando a partir de 1946 e depois de meados da década de 1950, respectivamente com a produção siderúrgica e petroquímica. Somado à falta de identificação de casos que certamente ocorreram, e às limitações da cultura de saúde do trabalhador à época, praticamente inexistente, configura o quadro de descolamento entre legislação e realidade já apontado anteriormente. 
No segundo período a situação já é bastante diferente. Continua não havendo referências em relação à legislação, mas combinadas com as informações sobre o aumento da produção e uso do benzeno há evidências importantes de situações de risco e de descontrole nos processos de trabalho, de exposições significativas em inúmeros setores produtivos em que o benzeno passou a ser utilizado, entre outros motivos devido à velocidade da difusão de seu uso. Quanto à questão central da relação entre medidas restritivas e evolução da prevenção, neste segundo período, assim como no primeiro, não há qualquer contribuição da restrição legal existente para a exposição de mulheres e menores. Pelo contrário, no segundo período, o tipo de uso de benzeno que aumenta é a sua utilização como solvente, em indústrias que empregam na maioria mulheres e que de forma indireta atingem também menores, num conflito direto com a lei, que ocorre sem que haja reações ou sequer comentários quanto à existência desta legislação.

Mesmo a legislação de 1972 sobre aposentadoria especial não tem repercussão visível, ao menos do ponto de vista da história do benzeno. Somente depois de 1978, com a instituição da portaria 3214 e o estabelecimento dos limites de tolerância, será possível identificar as primeiras reações a esta legislação nos trabalhos apresentados no Congresso Brasileiro de Prevenção de Acidentes de Trabalho de 1980, em que a indústria petroquímica foi uma das prioridades. Não apenas o trabalho sobre a PQU tem o Limite de Tolerância para o benzeno como uma das referências, como outras empresas do ramo químico apresentam trabalhos relacionando exposição a 
benzeno e alterações hematológicas, sempre preocupadas com a questão do Limite de Tolerância.

Os achados sobre a toxicidade e carcinogenicidade do benzeno foram sendo feitos ao longo dos anos, quase sempre correlacionados com os padrões de exposição existentes, que variaram nestes períodos assim como variaram os cenários onde ocorria exposição. Apesar da diminuição do número de estudos feitos nos países centrais, Estados Unidos e Europa principalmente, e da mudança de sua orientação, priorizando a pesquisa de riscos a baixas concentrações e os aspectos ambientais desta questão, é razoável supor que há diferença nos padrões de exposição daqueles países em relação ao Brasil, sendo possível identificar em nosso país uma diferença significativa de tempo, com em relação àqueles países, nas ocorrências de agravos, sugerindo um aparecimento tardio que corresponde ao desenvolvimento industrial também tardio, típico da relação entre aqueles países e os países periféricos.

No caso particular do benzeno deve ser considerada ainda a reestruturação produtiva relacionada com o processo de globalização que atinge todos os países. As cadeias produtivas do petróleo e aço, em que há presença significativa de benzeno, se deslocam para os países periféricos de forma cada vez mais significativa, puxados pela China que se tornou a "fábrica do mundo" e que ocupa um lugar decisivo hoje na produção de bens materiais e tecnologia. Acompanhando este crescimento, o aumento potencial da capacidade produtiva destas cadeias no Brasil já está em andamento, tornando praticamente inexorável nossa convivência com esta substância a longo prazo e 
aumentando ainda mais a importância de enfrentar as questões postas pela necessidade de prevenirmos a exposição ao benzeno.

A restrição da produção e utilização do benzeno no Brasil para apenas alguns tipos de empresas tem se mostrado correta e bem sucedida, tendo sido estabelecido um acompanhamento deste grupo de empresas através do controle da compra e venda do produto. Isto permite supor que o eventual uso desta substância por empresas fora do grupo cadastrado ocorra de forma marginal, além de evidentemente ilegal, o que permitiria ações de intervenção com boas probabilidades de sucesso. Este grupo de empresas, no entanto, não é homogêneo, havendo grandes diferenças entre as siderurgias, as refinarias, as petroquímicas e químicas de segunda geração, e as empresas de armazenamento e transporte.

$\mathrm{Na}$ siderurgia é possível identificar um grande desgaste das organizações sindicais e das discussões sobre saúde do trabalhador, particularmente na segunda metade da década de 90 quando, logo após o processo de privatização, houve uma grande inflexão da produção de aço no mundo, repercutindo de forma negativa nestas empresas, em especial na Cosipa. Essa empresa é emblemática desta discussão no Brasil e no mundo, pois a exposição a benzeno na atividade siderúrgica é pouco valorizada, e a experiência brasileira um caráter pioneiro nesse e em outros aspectos. Sintomaticamente, em meados de 2007 , três mortes de trabalhadores ligados à Cosipa exemplificaram os vários ciclos de adoecimento e morte ligados a essa atividade e pouco identificados em nosso país: um dos trabalhadores, afastado 
na década de 80 e aposentado na década de 90, foi diagnosticado com uma Leucemia Mielóide Aguda que teve evolução rápida e fatal; outro trabalhador, com diagnóstico de Leucemia Linfóide Crônica realizado em 1997, faleceu após 10 anos; finalmente um jovem trabalhador de empresa terceirizada, que teve diagnosticada uma Leucemia Linfóide Crônica em 2004, foi afastado e transplantado, retornou à empresa após a alta, e teve recidiva com óbito em menos de 6 meses.

O setor siderúrgico é, no momento, um dos possíveis carros chefe da ampliação da produção industrial em curso no Brasil, havendo a expectativa de que este setor aumente sua capacidade produtiva, constituída ao longo de 60 anos, em até duas vezes e meia num período de aproximadamente 10 anos. Do ponto de vista da saúde do trabalhador, há poucas perspectivas de enfrentamento destas questões neste cenário. A questão ambiental é, no entanto, muito significativa, pelo impacto destas industrias eletro-intensivas e com grande potencial de contaminação, sendo este um caminho importante para levar a discussão necessária sobre um crescimento que não seja predatório para o ambiente e as comunidades, inclusive a dos próprios trabalhadores destas industrias.

O setor do petróleo chama a atenção pelo seu envolvimento na discussão nos últimos anos, participação que pode ser atribuída à presença dos trabalhadores deste setor na Comissão Nacional Permanente do Benzeno, e ao desenvolvimento de inúmeras ações de formação e intervenção nos locais de trabalho a partir de articulações entre técnicos do poder público e 
representantes de trabalhadores. Não foram encontrados registros de ações sobre o benzeno neste setor antes de 1997, e não houve sequer participação da Petrobrás no processo de negociação ocorrido em 1994/95. Trata-se de uma situação que chama a atenção, pois, internacionalmente, a participação da industria do petróleo é bastante significativa, sendo possível encontrar inúmeros trabalhos técnico-científicos, assim como a organização e a participação em eventos, muitas vezes realizados por órgãos de pesquisa tecnológica e científica próprios, outras vezes feitos em associação com universidades.

Na maior parte dos países hoje, há presença de benzeno na gasolina em níveis superiores a 1\%, sendo a discussão da toxicidade do benzeno em baixas concentrações, nos produtos e no ambiente, fundamental para estas corporações. Assim, a participação da Petrobrás conseguida desde 1995 expressa um avanço, ao mesmo tempo em que permite identificar a ocorrência de inúmeras situações de risco ainda existentes nas atividades industriais ligadas a este setor e, não menos importante, as múltiplas questões ambientais também com ele relacionadas.

Nos setores petroquímico e químico de segunda geração é possível identificar maior capacidade de diálogo, sendo que é nestes setores que a discussão sobre boas práticas, sistemática que vem sendo implementada nas ações de vigilância, mais tem avançado. O setor de armazenamento têm sido acompanhado há relativamente pouco tempo sendo possível, no entanto, diferenciar a estrutura de armazenamento que faz parte diretamente da indústria de refino de petróleo, daquela que armazena e distribui combustíveis, 
não incluída na legislação, e ainda daquela que armazena benzeno e misturas com grande concentração destas substâncias, geralmente para exportação, na área portuária.

O fato das atividades de vigilância da saúde estarem concentradas nos setores industriais anteriormente relacionados expressam uma limitação importante do alcance do acordo e da legislação referentes ao benzeno, que são voltados essencialmente para o núcleo dessas cadeias produtivas, que participam da discussão desde seu início, mas que no entanto são pouco capazes de responder às necessidades de intervenção nos seus campos periféricos, como a distribuição e venda de combustíveis e a recuperação de solventes, áreas em que não há praticamente nenhum tipo de ação de vigilância.

A questão da doença é um fator mobilizador importante, embora haja muita dificuldade para se fazer o diagnóstico, particularmente das alterações hematológicas relacionadas com a exposição ao benzeno. Estas dificuldades se agravam devido aos problemas de acolhimento do trabalhador intoxicado, cujo quadro clínico enfrenta grande resistência por parte das empresas e da previdência social para seu reconhecimento, sendo o trabalhador também com freqüência discriminado, principalmente quando se identifica grande número de casos com potencial de impacto importante nos processos produtivos e na vida das comunidades envolvidas.

A experiência brasileira de luta contra a exposição ao benzeno e suas conseqüências é extremamente rica e, em muitos casos, exemplar. Destacam- 
se a importância da produção técnico-científica como base das ações, o que pode ser identificado já nos anos 70 e que teve momentos marcantes no início das décadas de 80 e 90 . É também significativa a combinação desta produção com situações institucionais favoráveis, em geral decorrentes da abertura de espaços na sociedade, quase sempre vinculada aos movimentos sociais e às situações políticas.

Apesar de seus muitos limites e desafios, sendo um dos principais o envolvimento dos trabalhadores terceirizados e dos ramos de atividade menos organizados, que não estão contemplados diretamente no acordo e na legislação, como por exemplo os frentistas de postos de gasolina e os trabalhadores de oficinas mecânicas, a experiência brasileira de luta contra a exposição ao benzeno é um exemplo bem-sucedido de vigilância da saúde em que as estratégias de articulação entre trabalhadores e serviço público, com a preservação da autonomia de cada setor; de priorização das atividades de formação e de opção por formas participativas de atuação ajudam a entender e enfrentar os desafios da luta em defesa da saúde do trabalhador no Brasil. 


\section{CONCLUSÕES}

As restrições legais impostas à exposição ao benzeno, quando dissociadas do contexto sócio-histórico, como ocorreu nos 50 primeiros anos de o período analisado, não tiveram qualquer impacto na prevenção da exposição ao benzeno no Brasil. No período subsequente ao contrário, as medidas impactaram de maneira bastante positiva com grande inserção na dinâmica social, o que contribuiu para a evolução destas legislações. Apesar dos avanços significativos ainda há desafios importantes a serem superados.

1. A reconstituição histórica realizada mostrou uma riqueza muito grande na regulamentação da exposição ao benzeno, não apenas nas restrições legais, mas em todo o corpo jurídico-administrativo de vigilância à saúde construído ao longo de anos, com acentuado caráter participativo em boa parte destes momentos, que foi incorporado à própria legislação.

2. Ocorreram mudanças significativas nos padrões de exposição. Em muitos setores produtivos a exposição ao benzeno deixou de existir com a proibição da presença desta substância em solventes. Aonde ainda é permitida utilização de benzeno existem, em geral, melhoras importantes nos últimos anos, com padrões diferenciados dependendo de cada setor. As industrias petroquímica e química têm uma melhor compreensão do conceito de não exposição e um melhor trato da política de boas práticas. As atividades de avaliação ambiental quantitativas ainda demandam muita evolução. 
3. O grande aumento no reconhecimento dos agravos à saúde ocorrido a partir de 1980, com a superação do silêncio existente até então, se deve a múltiplos fatores, entre os quais se destacam o acúmulo técnico-científico existente naquela época, em especial na área da saúde pública, e a intensa dinâmica social, com a participação dos sindicatos de trabalhadores que contribuíram de forma decisiva para superar a fragmentação dos órgãos públicos. Com o refluxo desta mobilização, nos anos 1990, há uma inflexão neste reconhecimento, que permanece até o presente momento, independente da evolução no processo de normatização. Este é o principal desafio a ser superado no atual estágio.

4. As ações realizadas no Brasil consolidaram um modelo de vigilância da saúde bem sucedido, baseado principalmente em aspectos qualitativos e de participação, com grande dinâmica social. Do ponto de vista internacional parece haver uma excessiva valorização dos aspectos quantitativos, sendo difícil identificar, em especial nos países centrais, se houve uma retomada dos estudos que ocorriam até os anos 1980 e se os trabalhadores e o poder público têm informações sobre o que se passa nas empresas desses países. Apesar dos muitos limites do processo brasileiro, parece haver possibilidades significativas de evolução. 


\section{REFERÊNCIAS BIBLIOGRÁFICAS}

Alessio L, Maroni M, Forni A. Patologia da idrocarburi aromatici. In: Sartorelli E. Tratatto di Medicina del Lavoro. Padova:Piccin Editore, 1981

Aksoy M, Erdem S. Follow up study on the mortality and the development of leukemia in 44 pancitopenic patients with chronic exposure to benzene. Blood. August 1978; 52(2): 285-292

Aksoy M. Benzene as a Leukemogenic and Carcinogenic Agent. Am. J. Ind. Med. 1985; 8:9-20

Aksoy M. Benzene Carcinogenicity. Boca Raton, CRC Press Inc., 1987

Andrade C, Timossi A. Removedores e Solventes. Saúde Ocupacional e Segurança. 1971; 6(4):95-96

Apostoli $\mathrm{P}$, Alessio L. Fattori condizionanti assorbimento e metabolismo del benzene. In: Minoya C, Apostoli P, Bartolucci GB. Il benzene: tossicologia, ambiente di vita e di lavoro. Milano, Morgan Edizioni Tecniche, 1995, p.17-26

Arcuri AS, Cardoso LMN (org). Acordo e Legislação sobe o Benzeno - 10 anos. São Paulo, Fundacentro, 2005.

Augusto LG. Estudo longitudinal e morfológico (medula óssea) em pacientes com neutropenia secundária à exposição ocupacional crônica ao benzeno [dissertação]. Campinas, Universidade de Campinas, 1991.

Augusto LG et al. Alterações Histológicas de Medula Óssea Secundaria à Exposição ao Benzeno e a Evolução Hematológica do Sangue Periférico em Pacientes Acometidos. Revista Brasileira de Saúde Ocupacional. Agosto/Setembro 1993;21(78)

Augusto L, Novaes T. Ação Médico-Social no Caso do Benzenismo em Cubatão, São Paulo: uma Abordagem Multidisciplinar. Cadernos de Saúde Pública, Outubro/Dezembro 1999;15(4):729-738

Barale R. Genotossicitá del benzene. In: Minoya C, Apostoli P, Bartolucci GB. Il benzene: tossicologia, ambiente di vita e di lavoro. Milano, Morgan Edizioni Tecniche, 1995, p. 41-50 
Bartolucci GB, Alessandro G, Saia B. Evoluzione storica della patologia professionale da benzene. In: Minoya C, Apostoli P, Bartolucci GB. Il benzene: tossicologia, ambiente di vita e di lavoro. Milano, Morgan Edizioni Tecniche; 1995, p.69-80

Cardoso LMN, Arcuri SA. Relatório de visita à Companhia Siderúrgica Tubarão. [mimeo]. São Paulo, Fundacentro, 1989

Brasil, Ministério do Trabalho. Acordo e Legislação sobre o Benzeno. São Paulo: Fundacentro, 1995

Brasil, Ministério da Saúde. Risco químico: atenção à saúde dos trabalhadores expostos ao benzeno. Serie A. Normas e Manuais Técnicos. Brasilia: Editora do Ministério da Saúde, 2006

Carvalho AB, Arcuri A, Bedrikow B, Augusto LG, Oliveira LC, Bonciani M, et al. Benzeno - Subsídios técnicos à Secretaria de Segurança e Saúde no Trabalho (SSST/MTb); 2 ${ }^{\underline{a}}$ ed. São Paulo, Fundacentro, 1995

Castelman BI, Ziem GE. Corporate influence on the Thresold Limit Values. Am. J. Ind. Med., 1998; 13: 531-559

Cocheo V. Evoluzione dell'esposizione ambientale a benzene. In: Minoya C, Apostoli P, Bartolucci GB. Il benzene: tossicologia, ambiente di vita e di lavoro. Milano, Morgan Edizioni Tecniche; 1995, p.81-88

Coimbra W, Costa MB, Magro JE, Chu WL, Batista JC. Relatorio de inspeção das condições de exposição ao benzeno e seus derivados na área da Companhia Siderúrgica de Tubarão - CST [mimeo]. Vitoria, INSS/ DRT, 1991

Corrêa MJM. A construção social do silêncio epidemiológico do benzenismo: uma história negada. [dissertação]. Rio Grande do Sul, PUC, 2008

Cosipa. Relatório do grupo de trabalho para estudo da leucopenia [mimeo]. Cubatão, 1985

Costa, D. Relatório da Análise de Hemogramas dos Trabalhadores da Coqueria e Carboquímicos da Cosipa. In: Fundação Osvaldo Cruz - Ministério da Saúde. Repertório Brasileiro do Benzeno [CD-Rom]. Rio de Janeiro, 1996

Costa D. Benzeno: uma Negociação Exemplar. In: Bonciani M (org.) Saúde, Ambiente e Contrato Coletivo de Trabalho - Experiências em Negociação Coletiva. São Paulo, LTr Editora Limitada, 1996, p.118-132 
DIESAT. Trabalho \& Saúde. São Paulo, Set/Dez 1984, Ano IV, no 4/5 (Edição especial)

Freitas N, Arcuri SA. O Benzeno e a Saúde dos Trabalhadores - A Luta Histórica e a Negociação Tripartite. In: Bonciani M (org.) Saúde, Ambiente e Contrato Coletivo de Trabalho - Experiências em Negociação Coletiva. São Paulo, LTr Editora Limitada, 1996, p.71-117

Galvanese FAC. Estudo de caso sobre a legislação sanitária e o direito à saúde: o estado, a sociedade e a proteção da saúde de trabalhadores em Santo André, 1992 [dissertação]. São Paulo, Universidade de São Paulo, 1999.

Goldstein B. Introduction: Occam's Razor Is Dull. Environmental Health Perpectives, 1989; 82: 3-6

Hayes RB et al. Benzene and Limphohematopoietic Malignancies in Humans. Am.J.Ind.Med, 2001. 40:117-126

Hayes RB, Yin SN, Dosemeci M, Li GL, Wachholder S, Travis LB, et al. Benzene and the dose-related incidence of hematologic neoplams in China. Journal National Cancer Institut, 1997; 89: 1065-1071

Hobsbawn E. Era dos Extremos. O Breve Século XXI, 1914-1991. São Paulo: Editora Schwarcz Ltda., 2ª edição, 1996

Holmberg B, Lundberg P. Benzene: Standards, ocurrence and Exposure. Am. J. Ind. Med., 1985; 7:375-383

Horta RO. Benzenismo na Refinaria de Manguinhos. In: Fiocruz-Ministério da Saúde. Repertório Brasileiro do Benzeno, 3ā. Edição [CD-Rom].

Rio de Janeiro, 2005

Hunter D. The diseases of occupations. London, English Universities Press Ltd., 1955

Infante PF, White MC. Projections of Leukemia Risk Associated with Occupational Exposure to Benzene. Am.J.Ind.Med. 1985; 7:403-413

Infante PF. Benzene: an historical perspective on American and European occupational setting. In: Late lessons from early warnings: the precautionary principle 1896-2000. 2002

Lan Q et al. Hematotoxicity in Workers Exposed to Low Level of Benzene. Science, December 3, 2004; 306: 1774-1776 
Lianza S, Zidam L. Relatório de formação em saúde e segurança no Brasil. (mimeo). São Paulo: CUT, 2003

Loewenson R. Globalization and occupational health: a perspective from southern Africa. Bulletin of the World Health Organization.

Genebra, 2001; 79 (9)

Lopes JSL (org), Antonaz D, Prado R, Silva G (org). A ambientalização dos conflitos sociais. Participação e controle público da poluição industrial. Rio de Janeiro: Relume Dumará, 2004

Machado JMH et al. Alternativas e processos de vigilância em saúde do trabalhador relacionados à exposição ao benzeno no Brasil. Ciência e Saúde Coletiva, 2003; 8 (4): 913-921

Magrini RO. Novas Relações Trabalhistas de Segurança e Saúde do Trabalhador desenvolvidas no estado de São Paulo e no Brasil. [tese]. São Paulo, Universidade de São Paulo, 1999

Maluf EMCP. Epidemiologia da anemia aplástica adquirida severa: um estudo caso-controle realizado o Brasil. Curitiba: Ed. do Autor, 2001

Mendes R, Waissmann W. Aspectos históricos da Patologia do Trabalho. In: Mendes R. Patologia do Trabalho. São Paulo, Atheneu, 2ª̃ed., 2005.

Vol 1, p.3-46

Menezes AJP. Considerações a respeito das alterações hematológicas nas doenças profissionais - Prática 4. Imprensa Médica, 1946

Miranda CR, Dias CR, Oliveira LCC, Pena PGL. Benzenismo no complexo petroquímico de Camaçari, Bahia. Revista Brasileira de Saúde Ocupacional, 1997; v. 24, n. 89/90.

Morrone LC , Andrade M. Anemia Aplástica pelo benzeno em uma indústria de equipamentos plásticos - ocorrência de quatro casos fatais. In: Anais do XIII Congresso Nacional de Prevenção de Acidentes do Trabalho, 1974; p 733-739

Musu T. REACH en el Trabajo. Como se beneficiarán los trabajadores de la nueva política europea sobre agentes químicos ? ETUI-REHS, 2006

Naoum PC, Mourão CA, Ruiz MA. Alterações hematológicas induzidas por poluição industrial em moradores e industriários de Cubatão, SP Rev. Saúde Pública, 1984; 18:271 
Novaes TCP, Gruenzner G. Determinação dos teores de benzeno em solventes orgânicos industriais comercializados no Brasil e propostas para prevenção do risco potencial de benzolismo. Revista Brasileira de saúde Ocupacional, 1981; 9 (36):66-70

Novaes TCP. Bases Metodológicas para Abordagem da Exposição Ocupacional ao Benzeno [dissertação] São Paulo, Universidade de São Paulo, 1992

Pedro LCF. Riscos na produção do benzeno na indústria siderúrgica. Rev. Saúde Ocup. Seg., julho/agosto 1983, Ano XVIII, n.4

Reis, MM. Avaliação de risco de benzeno em Volta Redonda: as incertezas na avaliação da exposição [dissertação] Rio de Janeiro, Escola Nacional de Saúde Pública, 2004

Ruiz MA. Estudo Morfológico da Medula Óssea em Pacientes Neutropênicos da Industria Siderúrgica de Cubatão Estado de São Paulo [tese]. Campinas, Universidade de Campinas, 1989

Ruiz MA, Vassallo J., Souza CA. Alterações hematológicas em pacientes expostos cronicamente ao benzeno. Rev Saúde Pública, 1993; 27(2):145-151

Ruiz MA, Lorand-Metze I, Augusto LGS, Souza CA. Characteristics of the hemopoietic abnormalities after chronic exposure to benzene, Leukemia Research, 1994; v. 18 (supl)

Santos C. Quando os elos se partem [mestrado]. Rio de Janeiro, Fiocruz, 2003

Schorling I e Lind G. Reach - The only Plante Guide to the Secrets of Chemicals Policy in EU. What Happened and Why? 2004. Disponível em: http://www.mp.spe

Silva EP, Correa EC. Prevenção do Benzolismo na Industria Petroquímica. In: Anais do XVIII Congresso Brasileiro de Prevenção de Acidente do Trabalho, 1980; p122-125

Sindimetal. Documento relacionado ao benzeno da CST, desde 1990 até a presente data, março de 2005.(mimeo). Vitoria, 2005.

Sindiquim. Dossiê sobre doenças ocupacioanis e acidentes no polo petroquímico de Camaçari, Bahia. Especial Benzeno. Comissão de Saúde, Salvador, 1992. 
Siqueira CE. Dependent convergence: the struggle to control petrochemichal hazards in Brazil and United States. New York: Baywood Publishing Company, Inc., 2003

Snyder R. Benzene and leukemia. Critical Reviews in Toxicology, 2002; 32(3):55-210

Wakamatsu CT. Contribuição ao Estudo da Exposição Profissional ao Benzeno em Trabalhadores de Industrias de Calçados [dissertação]. São Paulo, Faculdade de Saúde Pública da Universidade de São Paulo, 1976

Wakamatsu C, Fernícola N. Intoxicação Profissional por Benzeno. In: Mendes R. Medicina do Trabalho e Doenças Profissionais. São Paulo: Sarvier, 1980

World Health Organization. Environmental Health Criteria 150: Benzene. Genebra, WHO, 1993

Yergin DO. Petróleo: uma história de ganância, dinheiro e poder. São Paulo: Scritta, 1992

Yin SN, Li Q, Lin Y, Tian F, Du C, Tin C. Occupational Exposure to benzene in China. British Journal of Industral Medicine, 1987; 44: 192-195 